Universidade de São Paulo

\author{
Instituto de Física \\ Instituto de Química \\ Instituto de Biociências \\ Faculdade de Educação
}

Talita Eloá Mansano Navarro

\title{
UTILIZAÇÃo DIDÁTICA DE IMAGENS POR FORMADORES DE FUTUROS Professores de CiÊNCIAS
}


FICHA CATALOGRÁFICA

Preparada pelo Serviço de Biblioteca e Informação do Instituto de Física da Universidade de São Paulo

Navarro, Talita Eloá Mansano

Utilização didática de imagens por formadores de futuros professores de ciências. - São Paulo, 2013.

Dissertação (Mestrado) - Universidade de São Paulo, Faculdade de Educação, Instituto de Física, Instituto de Química e Instituto de Biociências.

Orientador: Profa. Dra. Suzana Ursi.

Área de Concentração: Biologia

Unitermos: 1. Biologia (Estudo e ensino); 2. Formação de professores ; 3. Imagem digital; 4. Educação; 5. Didática

USP/IF/SBI-030/2013 
Talita Eloá Mansano Navarro

\section{“UTILIZAÇÃo DIDÁTICA DE IMAGENS POR FORMADORES DE FUTUROS \\ Professores de CiênCIAS"}

Dissertação de Mestrado apresentada ao Instituto de Física, ao Instituto de Química, ao Instituto de Biociências e à Faculdade de Educação da Universidade de São Paulo para a obtenção do título de Mestre em Ensino de Ciências.

\section{Orientadora: $\operatorname{Prof}^{\mathrm{a}} \mathrm{Dr}^{\mathrm{a}}$ Suzana Ursi}

São Paulo

2013 


\section{DEDICATÓRIA}

"Eu dedico esta pesquisa a minha mãe Aparecida M. Navarro por ter me apoiado e acreditado que eu era capaz de realizar esse nosso sonho e ao meu marido Alison Mansano de Oliveira pelo carinho e compreensão durante esse longo período de produção". 


\section{AGRADECIMENTOS}

A elaboração deste trabalho não teria sido possível sem a colaboração, estímulo e empenho de diversas pessoas, por isso gostaria de manifestar meus sinceros agradecimentos a todos que fizeram parte desse meu percurso.

À minha Orientadora Prof ${ }^{\mathrm{a}}$. Dr ${ }^{\mathrm{a}}$ Suzana Ursi, por todas as horas dedicadas a leitura e releitura do meu trabalho, inclusive durante sua licença gestante, tendo que abrir mão de estar com o pequeno Vinicius. Agradeço pelas sugestões e críticas que transformavam meu texto confuso em algo claro e coerente. Pelo grande entusiasmo e incentivo dando novas ideias de como prosseguir. E principalmente, por ter me acolhido e me dado liberdade para pesquisar "as imagens" mesmo não sendo sua especialidade e assim, pudemos juntas ir aprendendo mais sobre esse tema tão intrigante.

Aos meus amigos do grupo de pesquisa BOTED (Grupo de Pesquisa e Extensão Botânica na Educação) por todo o apoio que me deram e suas sugestões que foram cruciais para que eu chegasse até aqui. Principalmente, ao João Rodrigo Silva pela sua análise atenta do texto e suas correções, enquanto a Suzana estava de licença gestante, te agradeço profundamente muito por ter gasto tanto tempo para me ajudar.

Á minha grande amiga e ex-orientadora Prof ${ }^{a}$. Dr ${ }^{a}$ Celi Rodrigues Chaves Dominguez, sem ela eu nunca teria chegado até aqui. Foi graças a ela que me apaixonei pelo tema e fiz minhas primeiras leituras e investigações a respeito dele. Ela que me ensinou o que era fazer uma pesquisa científica e todos os passos de uma, bem como as normas de formatação de um texto científico. Foi ela a primeira a ler e me dar sugestões ao meu projeto de pesquisa e esteve comigo em todos os momentos! Você foi minha inspiração para ir mais além, um exemplo de que meu sonho era possível! Não tenho palavras suficientes para agradecer tudo que fez por mim, você foi, e continuará sendo, como uma mãe para mim.

Ao meu marido Alison Mansano de Oliveira, pelo grande apoio e dedicação que me deu em todos os momentos, por todas as horas e dias que tive que passar longe ou na frente de um computador para concluir esse trabalho, pela paciência que teve para me ajudar a formatar e imprimir o texto, por contar e recontar as imagens comigo, por todas 
as vezes que teve de me levar até a USP ou me esperar na estação de trem, por me consolar quando pensava que não iria conseguir e por acreditar em mim acima de tudo!

À minha mãe, Aparecida Mansano Navarro, por sempre acreditar em mim e não me deixar desistir, chegar até aqui sempre foi o nosso sonho e foi ela que nunca me deixou parar de sonhar, ela foi a primeira a acreditar em mim, mesmo quando nem eu acreditava, sem ela nunca chegaria até aqui! Aos seus olhos eu sou mil vezes melhor do que realmente sou e dez mil vezes mais capaz! Você sempre se orgulhou de mim, mesmo antes de ser capaz de lhe dar algum motivo para se orgulhar! Obrigado de todo coração, eu te amo muito!

Aproveito também para agradecer ao meu irmão, Ricardo Felipe Mansano Navarro, que mesmo sendo hiperativo e sem nenhuma paciência, sentou ao me lado e me ajudou a contar as imagens. Também ao meu pai, Ricardo Rezende Navarro, que levou incontáveis vezes a USP e nunca duvidou que eu chegasse até aqui. Agradeço a todos os meus familiares que acreditaram em mim!

Um especial agradecimento a minha banca examinadora de qualificação, o Prof. Dr. Marcelo Tadeu Motokane e a Prof ${ }^{\mathrm{a}}$. Dr ${ }^{\mathrm{a}}$ Celi Rodrigues Chaves Dominguez, pela leitura atenta do trabalho, pelas sugestões e críticas que permitiram que esse trabalho crescesse e amadurecesse.

Aos professores que me cederam os seus materiais didáticos para que eu pudesse analisa-los, além de aceitar minha presença em suas aulas para minhas observações iniciais. Quero agradecer também tudo que me ensinaram enquanto estava na graduação, me dando além de conhecimento, um exemplo de profissional e de pesquisador no qual sempre me espelhei.

Por último, a Universidade de São Paulo a ao Programa de Pós-graduação Inteunidades em Ensino de Ciência, por me oferecer à oportunidade de ampliar meus conhecimentos por meio desta pesquisa. 


\section{RESUMO}

As imagens são ferramentas comunicativas amplamente utilizadas na sociedade atual. Elas assumem importantes funções no meio educacional, sendo muitas vezes imprescindíveis na explicação de determinados conceitos. No entanto, elas não são autossuficientes. Existe a necessidade de serem exploradas, cabendo ao professor direcionar o olhar dos alunos, os auxiliando a atribuírem significado ao que estão observando e estabelecerem a relação da imagem com o conceito. É importante que o futuro professor do ensino básico, já durante seu processo de formação acadêmica, tome consciência dessa sua função como auxiliar na interpretação de imagens por parte de seus estudantes. Nessa perspectiva, é importante que docentes de cursos de formação de professores tenham especial atenção à maneira como utilizam as imagens em suas próprias aulas. $\mathrm{O}$ presente trabalho teve a intenção de ampliar o conhecimento sobre o uso de imagens na formação inicial de professores de Ciências, focando-se especificadamente a temática Biodiversidade. Para tanto, realizamos uma análise descritiva das imagens de materiais apresentados nas aulas de duas disciplinas ministradas durante o curso de Licenciatura em Ciências da Natureza que abordam essa temática: "Diversidade Zoológica" e "Diversidade Botânica". Os objetivos específicos foram: (1) quantificar as imagens utilizadas nas aulas; (2) realizar a análise morfológica das imagens, enfocando tipo, coloração, presença de escala e tamanho; (3) realizar a análise funcional das imagens, utilizando classificação própria, criada a partir de Duchashel e Waller (1979) e de Kress e Van Leeuwen (1996). Foi analisado um total de 1727 imagens. Verificamos que a existência de um padrão de utilização em todos os materiais investigados, sendo as imagens preferencialmente do tipo fotográfico, colorido e com função ilustrativa. O uso de escalas nas imagens foi praticamente nulo e não foi apresentada nenhuma legenda no material que lembre ao aluno que as imagens são apenas representações e que nem sempre correspondem a realidade, tendo tamanhos e cores aleatórias. Houve um número considerável de imagens com mais de uma função. Finalmente, percebemos a utilização de uma quantidade elevada de imagens em cada aula e muitas imagens por slide, sendo apresentadas cerca de 1,69 imagens por slide/página. Esses resultados evidenciam um perfil de utilização de imagens em aulas de Biologia voltadas à temática biodiversidade e fornecem subsídios para futuras investigações mais profunda, por exemplo, com base em observações sistemáticas das aulas e entrevistas individualizadas com os docentes. 


\begin{abstract}
ABSTRAT
Images are communication tool amply used in today's society. Also assume important functions in the educational and are often indispensable in explaining certain concepts. However, they are not self-sufficient. There is a need to be explored, and the teacher's responsibility to direct the gaze of students, helping to attach meaning to what they are watching and establish the relationship of the image with the concept. It is therefore important that future elementary school teacher, already during their academic learning process, be aware that its function as an auxiliary in image interpretation by their students. In this perspective, it is important that teachers training courses for teachers to have special attention to the way how they use the images in their own classes. This work was intended to expand the knowledge about the use of images in the initial training of Science teachers, focusing specifically the theme Biodiversity. Therefore, we performed a descriptive analysis of the images of materials presented in class two subjects taught during the Graduation Degree in Natural Sciences that address this theme: "Zoological Diversity" and "Diversity Botany". The specific objectives were: (1) quantify the images used in the classroom, (2) perform morphological analysis of images, focusing on type, color, presence of scale and size, (3) conduct a functional analysis of the images using our own classification, created from Duchashel and Waller (1979) and Kress and Van Leeuwen (1996). We analyzed a total of 1,727 images. We verified that the existence of a pattern of use in all materials investigated, and the images of the type preferably photographic, colorful and illustrative function. The use of scales in the images was practically nil and not has been any legend in material that the student remember that images are nothing more than representations and do not always correspond to reality, with random sizes and colors. There was a considerable number of images with more than one function. Finally, we see the use of a high amount of images in each class and many images per slide, being presented about 1.69 images per slide / page. These results show a profile of the use of images in biology classes focused on thematic biodiversity and provide subsidies for future investigations deeper, for example, based on systematic observations of classes and individual interviews with teachers.
\end{abstract}




\section{SUMÁRIO}

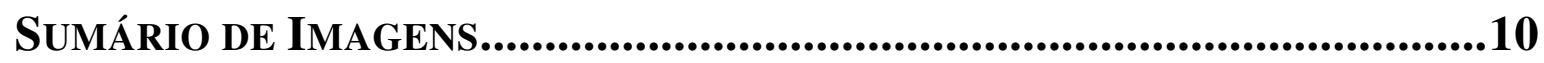

1. Objetivos da Pesquisa...............................................................13

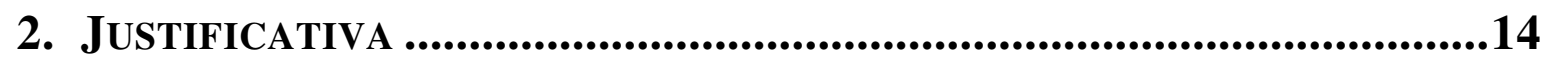

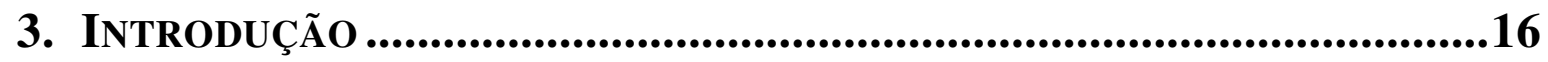

3.1 O Ser social e a Linguagem.........................................................................................................16

3.2 A Imagem ................................................................................................................................19

3.2.1 O Mundo das Imagens..................................................................................19

3.2.2 O que é a Imagem? ………………………………………………………......21

3.2.3 Classificações das Funções das Imagens .................................................................2

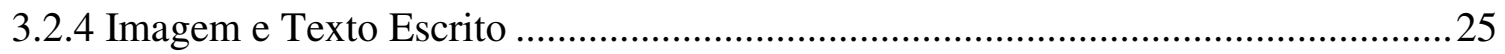

3.2.5 Imagem Fotográfica ………………………………………………………...2

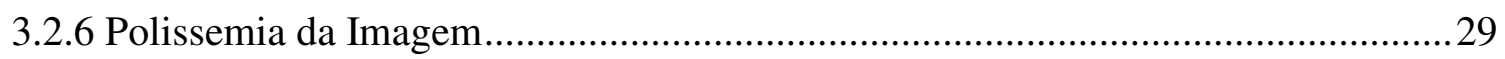

3.3 Alfabetização Visual .......................................................................................................31

3.4 Imagem como Recurso Didático..........................................................................................36

3.5 Formação de Professores ............................................................................................................40

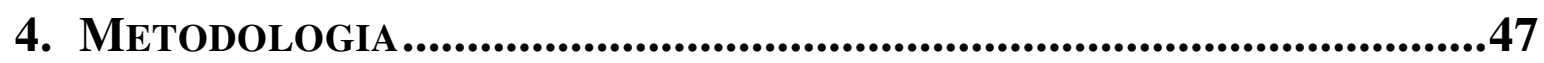

4.1 Natureza da Pesquisa ..................................................................................................................4

4.2 Sujeitos do Estudo e seu Contexto de Atuação ...............................................................50

4.3 Critérios utilizados para Análise das Imagens ................................................................54

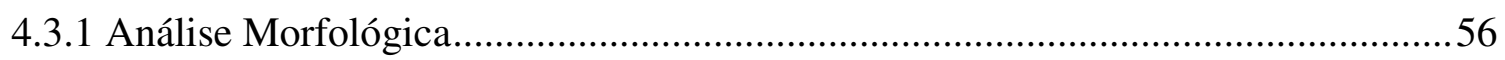

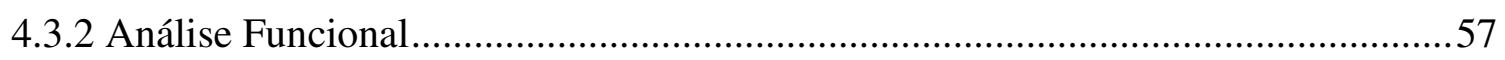

5. RESUltAdOS E DiSCUSSÃo ..........................................................64

5.1 Análise Morfológica das Imagens dos Materiais Didáticos ......................................65

5.1.1 Disciplina Diversidade Zoológica - Material elaborado pelo Prof. A ......................65

5.1.2 Disciplina Diversidade Zoológica - Material elaborado pelo Prof. B ......................68

5.1.3 Disciplina Diversidade Botânica............................................................................. 
5.2 Análise Funcional das Imagens do Material Didático............................................78

5.2.1 Disciplina Diversidade Zoológica - Material elaborado pelo Prof. A .....................78

5.2.2 Disciplina Diversidade Zoológica - Material elaborado pelo Prof. B .....................80

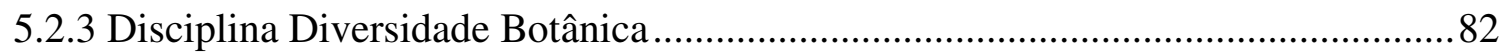

5.2.4 Discussão dos Dados da Análise Funcional ............................................................ 84

6. ConSIDERAÇÕES FINAIS......................................................................86

7. REFERÊNCIAS BIBLIOGRÁfICAS.................................................89 


\section{Sumário de Imagens}

\section{Figuras}

Figura 1- Menino, árvore e cachorro (imagem retirada da pesquisa de Silva e Cavassan, 2003).

Figura 2 - Exemplo de Imagem Composta .55

Figura 3 - Exemplo de Imagem Decorativa.... .59

Figura 4 - Exemplo de Imagem Ilustrativa 60

Figura 5 - Exemplo de Imagem Retentora. .60

Figura 6 - Exemplo de Imagem Retentora 2 .61

Figura 7 - Exemplo de Imagem Comparativa. .61

Figura 8 - Exemplo de Imagem Comparativa e Impactante .61

Figura 9 - Exemplo de Imagem Impactante 62

Figura 10 - Exemplo de Imagem Impactante 2. .62

Figura 11 - Exemplo de Imagem Constitutiva. .62

Figura 12 - Exemplo de Imagem Organizacional .63

Figura 13 - Exemplo de Imagem Processual 63 


\section{Gráficos}

Gráfico 1 - Tamanho das imagens analisadas a partir do material do Prof. A da disciplina Diversidade Zoológica.

Gráfico 2 - Tipo das imagens analisadas a partir do material do Prof. A da disciplina Diversidade Zoológica. .66

Gráfico 3 - Coloração das imagens analisadas a partir do material do Prof. A da disciplina Diversidade Zoológica.

Gráfico 4 - Tamanho das imagens analisadas a partir do material do Prof. B da disciplina Diversidade Zoológica.

Gráfico 5- Tipo das imagens analisadas a partir do material do Prof. B da disciplina Diversidade Zoológica.

Gráfico 6- Coloração das imagens analisadas a partir do material do Prof. B da disciplina Diversidade Zoológica. .70

Gráfico 7 - Tamanho das imagens analisadas a partir do material do Prof. de Diversidade Botânica. .72

Gráfico 8 - Tipo das imagens analisadas a partir do material de Diversidade Botânica. ....72 Gráfico 9 - Coloração das imagens analisadas a partir do material de Diversidade Botânica.

Gráfico 10 - Total de tipos de imagens analisadas a partir dos materiais dos três docentes.

Gráfico 11 - Análise funcional: categorias das imagens do material do Prof. A da disciplina

Diversidade Zoológica .79

Gráfico 12 - Análise funcional: categorias das imagens do material do Prof. B da disciplina Diversidade Zoológica. .81

Gráfico 13 - Análise funcional: categorias das imagens do material da disciplina de Diversidade Botânica. 


\section{Tabelas}

Tabela 1 - Escala de Iconicidade de Imagens segundo Moles (1981) .23

Tabela 2 - Modalidades de imagens explicativas segundo Duchastel e Waller (1979).......24

Tabela 3 - Classificação funcional de imagens utilizada na presente pesquisa. Classificação modificada a partir dos trabalhos de Duchastel e Waller, (1979) e de Kress e Van Leeuwen (2006) e incorporou dados obtidos por Navarro e Ursi (2012). .57

Tabela 4 - Cronograma da disciplina de Diversidade Zoológica .52

Tabela 5 - Tema das Aulas de Diversidade Botânica

Tabela 6 - Análise Morfológica das Imagens do Material da Disciplina Diversidade Zoológica (Prof. A) .65

Tabela 7 - Análise Morfológica das Imagens do Material da Disciplina Diversidade Zoológica (Prof. B) .68

Tabela 8 - Análise Morfológica das Imagens do Material de Diversidade Botânica. .71

Tabela 9 - Distribuição de Imagens dos Materiais Didáticos Analisados. .76

Tabela 10 - Análise Funcional das Imagens do Material Didático da Disciplina do Prof. A da Disciplina Diversidade Zoológica 78

Tabela 11 - Análise Funcional das Imagens do Material Didático da Disciplina de Diversidade Zoológica (Prof. B) .80

Tabela 12 - Análise Funcional das Imagens do Material da Disciplina do Prof. de Diversidade Botânica .82 


\section{ObJetivos da Pesquisa}

O presente trabalho pretende contribuir para a ampliação do conhecimento sobre as imagens utilizadas em cursos de formação inicial de professores de Ciências, focando-se na temática Biodiversidade. Para tanto, tem como objetivo geral realizar uma descrição das imagens apresentadas nas aulas de duas das disciplinas ministradas durante um curso de Licenciatura em Ciências da Natureza que abordam diversidade zoológica e diversidade botânica.

Os objetivos específicos são os seguintes:

- quantificar as imagens utilizadas nas aulas;

- realizar a análise morfológica das imagens, enfocando tipo, coloração, presença de escala e tamanho;

- realizar a análise funcional das imagens, utilizando classificação própria, criada a partir de Duchastel e Waller (1979) e de Kress e Van Leeuwen (2006). 


\section{JUSTIFICATIVA}

A presente pesquisa justifica-se inicialmente pela própria relação íntima existente entre a Ciência e as imagens. Sendo assim, tal relação também deve ser objeto de estudo durante cursos de formação inicial de professores de Ciências, como aquele que é foco da presente investigação.

Podemos afirmar que as imagens são ferramenta de grande utilidade para a Ciência. Elas ajudam os cientistas a observarem e interpretarem os fenômenos do mundo natural, possuindo uma ligação histórica com a construção do conhecimento da área. Por exemplo, no campo da Biodiversidade, desde o século XVII, já se dependia das imagens para divulgar conhecimentos por meio de desenhos feitos por naturalistas de novas espécies encontradas (BRUZZO, 2001).

As imagens auxiliam os cientistas a comunicarem seus conceitos e ideias, possibilitando identificar os principais pontos de análise e a discussão da relação entre os conceitos e as entidades neles representadas. Além de servir para a divulgação de resultados, a imagem também auxilia no próprio processo de construção das novas teorias, permitindo que o cientista organize melhor seus pensamentos. Um bom exemplo de um notório cientista que utilizou a ilustração para configurar e organizar suas ideias foi Faraday, que criou a consciência de campos eletromagnéticos principalmente através da visualização das linhas de forças (MARTINS; GOUVÊA, 2001).

A Ciência também faz uso das imagens numéricas que isolam informações a serem observadas e representam em números situações reais, tais como os gráficos. Saber ler essas imagens é essencial para entender a(s) mensagem(ns) que carrega(m).

Nas áreas científicas, as imagens são fontes de pesquisa e resultados de análises. Essa união entre Ciência e imagens é tão grande que acabamos por resumir conceitos por imagens e, muitas vezes, acreditamos demasiadamente no que as imagens nos mostram, esquecendo que elas são representações do real na visão do criador da imagem.

Tal como afirma Colom (2004, pg.123), “o homem não estuda a realidade, mas sim cria uma realidade que possa ser estudada com mecanismos narrativos que o homem possui”". A imagem é mais uma dessas ferramentas narrativas para registar o que observamos para uma análise posterior e, assim, nos auxilia no processo de compreensão do mundo em que vivemos. 
Mediante essa estreita relação Ciências-Imagem, fica clara a importância também de da relação para o Ensino de Ciências-Imagem. O professor deve ter consciência do papel das imagens na construção do saber científico e auxiliar seus estudantes a também desenvolverem tal consciência. Dessa forma, fica evidente a relevância de se investigar como ocorre a utilização de imagens em aulas de formação inicial de professores, sendo o diagnóstico sobre o tipo e a função de imagens um primeiro passo para ampliar o conhecimento na área.

Nesse contexto dos cursos de formação inicial docente, pouco espaço é normalmente destinado às discussões sobre o uso de imagens, embora tal problemática seja de extrema importância nos dias de hoje. Dessa forma, muitos licenciandos têm pouco preparo para trabalhar com as imagens de forma apropriada, propiciando uma real alfabetização visual em seus futuros alunos.

Nesse cenário, surgem alguns questionamentos: os professores da formação inicial usam imagens em suas aulas? Que tipos de imagens são utilizadas e com quais funções? Os docentes refletem sobre sua forma de utilização de imagens? Será que eles têm consciência das consequências da utilização descuidada? O que pensam sobre o uso de imagens como um recurso didático?

Tais questionamentos são bastante abrangentes e demandam longo tempo e reflexão para serem respondidos. No entanto, esperamos que a atual pesquisa evidencie a necessidade de se debater o tema da utilização de imagens nos cursos de formação docente e forneça, por meio do estudo de caso realizado, subsídios iniciais e básicos ao revelar tipos e funções de imagens utilizadas nas aulas do curso que é foco de nossa pesquisa. 


\section{INTRODUÇão}

\subsection{O Ser social e as Linguagens}

O ser humano é formado com base em seu convívio social e sua história, desse modo "o homem, ao nascer, não passaria de um candidato à humanidade", pois cada indivíduo, no decorrer de sua vida, "aprende a ser um homem, portanto não basta viver em uma sociedade, é preciso adquirir o que foi alcançado no percurso do desenvolvimento histórico da sociedade humana" (LEONTIEV, 1978, p. 267).

Conforme essas ideias, há uma necessidade de se compreender o mundo natural e social para que a humanidade seja conquistada. Assim, as crianças, ao longo da vida, vão criando significados para o que as cerca. Cabe ao professor, dentre outros atores sociais, facilitar esse processo de exploração do mundo.

O ser humano, desde o seu nascimento, vai se inserindo na sociedade na medida em que aprende práticas sociais e culturais durante as interações com os adultos e crianças de sua cultura. Aos poucos, ele irá internalizar aspectos objetivos e subjetivos da sua cultura, desde como agir até como pensar. A principal característica humana é sua elevada capacidade de aprender coisas novas e interagir com elas (BOCK et. al, 2002).

Enquanto a criança passa por esse processo de humanização, além de assumir-se como um ser social e apropriar-se de sua cultura, ela também é produtora de mais cultura, como defendem vários autores: Vygotsky (2000, 2003), Kishimoto (2001), Marcellino (2006), entre outros.

Tal socialização é mediada por signos, que são tão internalizados durante o decorrer de nossas vidas e que passam a fazer parte de nossas relações subjetivas e inconscientes. Nossa vida é permeada de signos e símbolos e vamos apropriando-nos cada vez mais deles, até que fazemos algumas associações automáticas, quase sem refletir. Algumas delas serão baseadas em estereótipos ou preconceitos de nossa cultura. Por exemplo, ao ver um homem com uma barba longa, alguns podem associar a imagem ao Papai Noel e outros ao terrorismo, dependendo das relações culturais que foram estabelecidas. Porém, alguns signos são convencionados mundialmente, de modo que seu significado é compreendido igualmente por todos, tal como algumas placas de trânsito ou, em um âmbito mais complexo, os conceitos científicos (NOVELLINO, 2007). 
Uma das principais características da humanidade é a linguagem. Ela nos permite ser o que somos hoje, além de ser uma das diferenças entre nós e nossos parentes evolutivos mais próximos. Pesquisas realizadas por Vygotsky (2003) com símios e com crianças pequenas revelaram que as crianças que ainda não dominaram a linguagem conseguem realizar as mesmas atividades e desafios que os chimpanzés. Contudo, quando adquirem a linguagem falada, as crianças ampliam sua possibilidade de mobilizar suas capacidades superiores, como refletir e planejar para solucionar problemas ou pegar objetos que não estejam ao seu alcance.

Por meio da linguagem, crianças podem interagir com um adulto ou com outras crianças, o que pode auxiliar na realização de determinadas tarefas ou na resolução de problemas que as mesmas não conseguiriam resolver sozinhas, potencializando seu nível de desenvolvimento.

Tais aprendizagens não estariam ao alcance do indivíduo em sua fase de desenvolvimento cognitivo se ele permanecesse sozinho. Em outras palavras, a interação social pode facilitar a aprendizagem, pois possibilita que os participantes da atividade ajudem-se mutuamente até tornarem-se capazes de realizar a mesma atividade sem ajuda (VYGOTSKY, 2003).

Para Vygotsky (1998, 2000, 2003), um grande avanço no desenvolvimento psicológico ocorre quando o indivíduo adquire a linguagem, pois é por meio dela que ele poderá interagir com os demais indivíduos, que irão lhe ajudar a se apropriar ainda mais de sua cultura e dar significado a suas aprendizagens. Durante as interações sociais, a criança adquire a capacidade de simbolizar. A linguagem é um sistema simbólico. Assim, ao se tornar capaz de utilizá-la, seu contato com o mundo passa a ser mediado pelo uso de símbolos.

O ser humano desenvolveu meios de comunicação que permitiram, ao longo da história, a transmissão de seus conhecimentos para as próximas gerações. Tais meios se tornaram mais diretos e objetivos com a criação da linguagem escrita, que surgiu partir de desenhos e símbolos, que passaram a ser cada vez mais simples, como verificamos nas letras atuais, embora em alguns países, ainda se utilizam os ideogramas, que se aproximam mais das imagens (ZATZ, 1992).

Ainda hoje, a linguagem primeiramente dominada ao longo da história do nosso desenvolvimento é a visual, por meio de imagens. O ser humano dá preferência ao visual, Isso ocorre porque ver é uma experiência direta e a visão representa o máximo de aproximação do que podemos obter da realidade (DONDIS, 2000). 
“A visão é veloz, de grande alcance, simultaneamente analítica e sintética. Requer tão pouca energia para funcionar e funciona a velocidade da luz, que nos permite receber e conservar um número infinito de unidades de informações em uma fração de segundos" (DONDIS, 2000, p.6).

A visão é o principal meio no qual nossa percepção se baseia, dado que $75 \%$ da percepção humana é visual, $20 \%$ é auditiva e apenas $5 \%$ advém dos demais sentidos (SANTAELLA, 1998). Assim, podemos entender porque normalmente os seres humanos tem uma preferência inata pelo meio visual.

Sendo assim, há um grande número de imagens na comunicação humana. Segundo Pereira e Souza (2000) somos "bombardeados" por uma quantidade de imagens sem precedentes na história. Vivemos em um mundo cercado de imagens e elas estão cada vez mais acessíveis. Basta ter um celular e já se pode tirar e manipular imagens com facilidade. Com isso, foi crescendo uma falsa ideia de que elas são cópias fiéis da realidade. Assumimos essa crença de modo subjetivo, sem refletir sobre os critérios que utilizamos para interpretar e compreender as imagens que estão ao nosso redor. O próximo item do presente texto foca-se justamente nessa importante forma de comunicação: a imagem. 


\subsection{A Imagem}

\subsubsection{O Mundo das Imagens}

A imagem é um dos principais meios de comunicação humana em todos os tempos, sendo uma forma de expressão da cultura desde a pré-história, quando desenhávamos nas cavernas para expressarmos nossas emoções. A própria escrita atual é uma evolução de tais desenhos para uma forma mais simplificada e simbólica (SANTAELLA; NÖTH, 2008).

As imagens são utilizadas para diversos fins. É por meio delas que o ser humano conceitua o mundo que o rodeia. Segundo Costa (2005), a cultura humana é fortemente ligada às imagens, pois é por meio delas que reconhecemos inimigos e amigos e a nós mesmos, diferenciamos presa e predador. É por meio delas que criamos nossas próprias imagens mentais para armazenar informações importantes. As imagens também podem gerar reflexões e se transformar em "uma bagagem de conhecimento, experiência e afetividade" (pg. 27). Podemos também criar novas imagens a partir de nossas emoções e experiências vivenciadas. Desenhos, pinturas e esculturas nos permitem compartilhar com outros seres humanos nossa relação com o mundo.

A comunicação visual foi a primeira a ser utilizada pela humanidade e continuou sendo o principal meio de comunicação por toda a idade média, já que o conhecimento da leitura e escrita era um privilégio de poucos. Mas, com a invenção da imprensa, livros e jornais passaram a ser acessíveis para toda a população. Muito embora as imagens ainda existissem com o papel ilustrativo, elas deixaram de ser a principal fonte de conhecimento e foram desvalorizadas pela ciência e pela educação que privilegiavam a escrita (RODRIGUES, 2007).

No século XIX, com o início do capitalismo e a globalização, surge a necessidade de comunicação entre pessoas de idiomas muito distintos, e assim a relação imagem-texto se tornou mais necessária. Já no século seguinte, com os grandes avanços das tecnologias de comunicação em massa, a imagem passou a ocupar um espaço não só comunicativo, mas também se tornou um auxiliar na pesquisa e no ensino. A imagem passou da posição de apenas um simples integrante da área das artes para ser vinculada a informação e conhecimento e utilizada até mesmo nas áreas científicas (RODRIGUES, 2007), como será abordado com mais detalhes posteriormente. 
Para Aumont (1993, pg. 314):

\begin{abstract}
“As imagens, isso é inegável, há mais de 100 anos multiplicam-se quantitativamente em proporções impressionantes e sempre crescentes. Além disso, percebemos que essas imagens invadem nossa vida cotidiana, que seu fluxo não pode ser contido. Donde o sentimento difundido de que vivemos na verdade a era da imagem, a ponto de os profetas mais ou menos inspirados anunciarem regularmente, com tristeza ou regozijo, a morte da escrita”.
\end{abstract}

Esse uso massivo de imagens nos meios de comunicação, principalmente no meio publicitário, nos levou ao que muitos autores chamam de uma verdadeira "civilização/sociedade de imagens", pois elas estão em toda parte do nosso dia-a-dia, uma verdadeira era da visualidade e da cultura visual (ROSSI, 2009).

Alguns autores veem essa invasão como prejudicial à sociedade por acabar com a imaginação, acreditando que as imagens invadem nossas vidas até quando não queremos. Defendem que sua existência bloqueia a nossa capacidade de criar uma imagem simbólica que represente um fato ou conceito livremente. Rangel e Cunha (2007) exemplificam sua posição com o exemplo de sucesso do cinema: a série de filmes de "Harry Potter". Ela é tão divulgada que é quase impossível não conhecer a imagem dos atores do filme. Mesmo que não se tenha visto o filme, ao ler o livro que deu origem à série, a maioria das pessoas já tem a imagem de Emma Waton no papel de Hermione, dificultando imaginar por si mesmo a personagem.

Já outros autores, como Iavelberg (1995), acreditam que o vasto número de imagens nos ajudam a aumentar nosso repertório de representações mentais, que podem ser modificadas e recombinadas no processo criativo. A imaginação está ligada à quantidade de experiências acumuladas. Portanto, quanto maior for o repertório de imagens mentais de um objeto, maior será a capacidade criativa. Toda a atividade humana que cria algo novo, a cria com base em seu repertório mental construído na vivência com o mundo exterior (Vygotsky, 2000). Dondis (2000, p. 230) afirma que "a inteligência visual aumenta o efeito da inteligência humana e amplia o espírito criativo. Não se trata apenas de uma necessidade, mas, felizmente, de uma promessa de enriquecimento humano para o futuro".

Há ainda autores, como Joly (2009), que veem a invasão de imagens no mundo contemporâneo como uma perda da sensibilidade humana, na qual deixaríamos de ser leitores das imagens para nos tornamos meros consumidores sem critérios. Joly (2009), logo no início de seu livro "Introdução à Análise de Imagens", afirma que seu objetivo é 
nos ajudar na superação do estado de meros "consumidores de imagens". Para a autora, quanto mais imagens vemos, mais em risco estaremos.

\footnotetext{
"Um dos motivos pelos quais elas parecem ameaçadoras é que estamos no centro de um paradoxo curioso: por um lado, lemos as imagens de uma maneira que parece totalmente 'natural', que, aparentemente, não exige qualquer aprendizado e, por outro lado, temos a impressão de estar sofrendo de maneira mais inconsciente do que consciente a ciência de certos iniciados que conseguem nos 'manipular', afogando-nos com imagens em códigos secretos que zombam de nossa ingenuidade" (JOLY, 2009, pg. 10).
}

Há, portanto, uma necessidade de realizarmos uma alfabetização visual (abordado em mais detalhes no item 3.3 da presente dissertação) e para isso, é necessário ampliar o conhecimento sobre essas imagens. Tão presentes em nosso cotidiano.

\subsubsection{O que é a Imagem?}

A palavra imagem é utilizada atualmente com tantos significados diferentes que se torna difícil conceituá-la com precisão.

\footnotetext{
"O termo imagem é tão utilizado, com tantos tipos de significação sem vínculo aparente, que parece bem difícil dar uma definição simples dele, que recubra todos os seus empregos. De fato, o que há de comum, em primeiro lugar, entre um desenho infantil, um filme, uma pintura mural ou impressionista, grafites, cartazes, uma imagem mental, um logotipo, "falar por imagens" etc.? O mais impressionante é que, apesar da diversidade de significações da palavra, consigamos compreendê-la. Compreendemos que indica algo que, embora nem sempre remeta ao visível, toma alguns traços emprestados do visual e, de qualquer modo, depende da produção de um sujeito: imaginária ou concreta, a imagem passa por alguém que a produz ou reconhece" (JOLY, 2009, pg. 13).
}

O mundo das imagens se divide em dois domínios: material e imaterial. O domínio material é o das representações visuais, tais como desenhos, pinturas, gravuras, fotografias, as imagens cinematográficas, televisivas e infográfica. Já o domínio imaterial é o das imagens mentais, são as visualizações por meio do pensamento e do inconsciente (SANTAELLA; NÖTH, 2008). 
Apesar de ambos os domínios não existirem separadamente, a presente pesquisa foca-se nas imagens do domínio material. Dessa forma, é relevante refletir sobre qual é o limite entre imagens mentais e materiais. Moles (1981) criou uma escala para separá-las com base em sua iconicidade, ou seja, no grau de realismo, já que toda representação visual é uma imagem, seja ela material ou mental (Tabela 1). Como a análise realizada no presente trabalho baseia-se em materiais impressos em um plano bidimensional, as imagens da pesquisa estão compreendidas dos níveis do 4 ao 9 de Moles (1981).

Toda imagem é uma representação de um ser, objetos ou fenômeno, mas o que seria uma representação? Na visão de Goodman (1968), representar é a principal função dos signos, entre eles, a descrição, a expressão e a exemplificação. Já Sperder (1985) utiliza o conceito de representação como sendo o próprio signo, separando-o em representações internas e externas, respectivamente. Para Peirce (1865), representar é uma relação com um "outro", de modo que ele seja codificado por nossa mente como sendo esse outro (SANTAELA; NÖTH, 2008).

Mitchel (1986, apud SANTAELA; NÖTH, 2008) introduziu o termo "iconologia" para designar a ciência do discurso da imagem, porém em uma visão diferente da utilizada pela arte. Assim criou uma classificação dos tipos de imagens: gráficas (desenhos, pinturas, esculturas), ópticas (espelhos e projeções), perceptíveis (dados de ideias e fenômenos), mentais (sonhos, lembranças, ideias, fantasias) e verbais, (metáforas e descrições). 
Tabela 1 - Escala de Iconicidade de Imagens segundo Moles (1981). Em destaque, níveis abordados no presente trabalho.

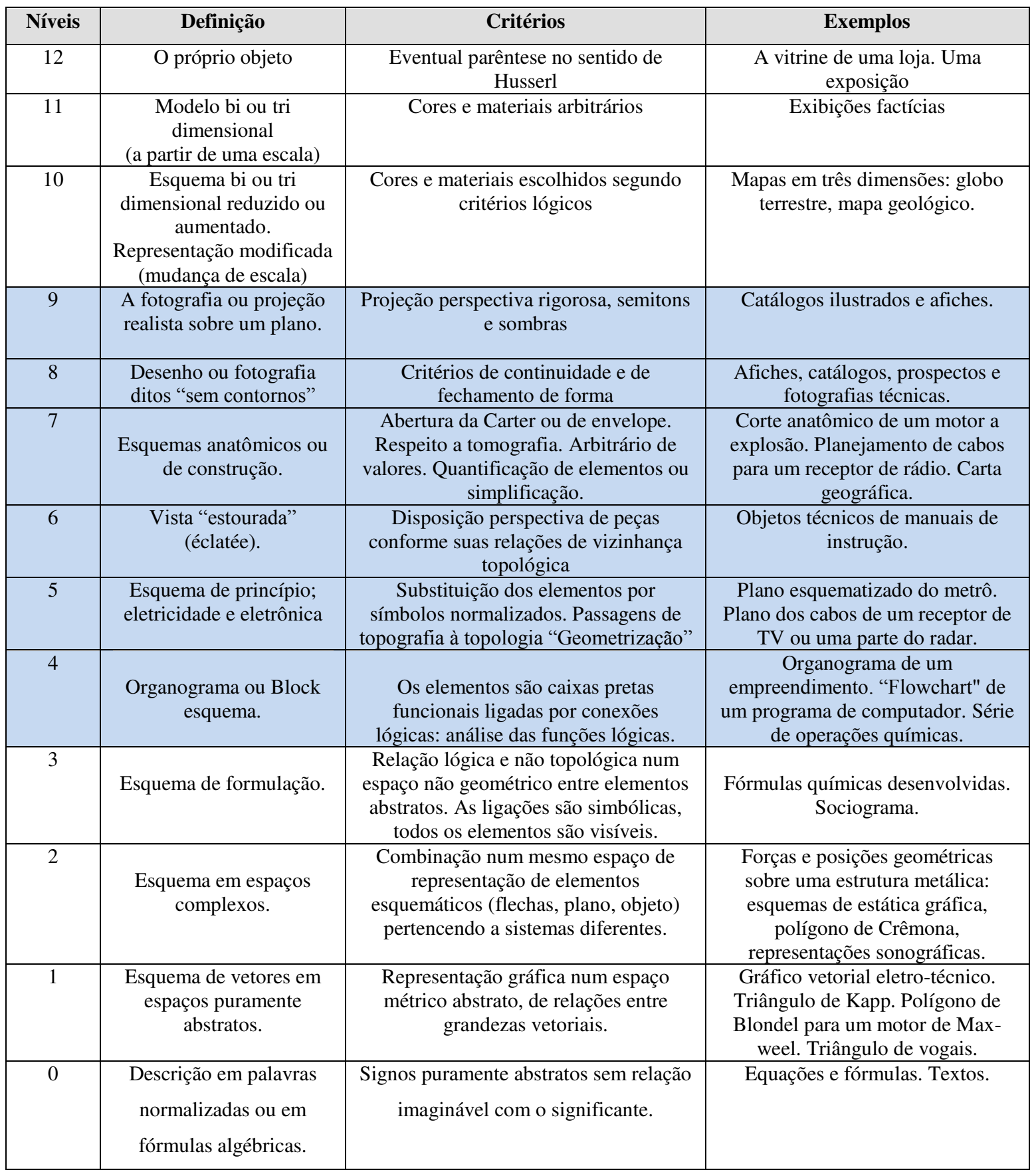

\subsubsection{Classificações das Funções das Imagens}

Aumont (1993) destaca três modos de utilização das imagens no decorrer do curso da história:

- Modo simbólico - imagem muito ligada à área religiosa ao longo da história. 
- Modo epistêmico - imagem que traz informações (visuais) sobre o mundo, podendo ser informações até sobre aspectos visuais.

- Modo estético - imagem que tem a função de transmitir sensações e emoções.

Segundo Duchastel e Waller (1979) existem três grandes funções para as imagens: atrativa (attentional), explicativa (explicative) e retentora (retentional). A primeira tem como objetivo captar a atenção do observador despertando-lhe o interesse pela leitura do texto expositivo, o assunto da imagem não necessita estar diretamente ligado ao texto em si, assim ela pode apresentar uma função mais decorativa do que explicativa. A segunda função, a explicativa, serve para auxiliar na explicação tornando um determinado assunto abordado no texto mais compreensível. Já imagem retentora é aquela que auxilia na memorização das informações disponíveis no texto, ex. um resumo em forma de imagem. Os autores apresentam sete modalidades de imagens explicativas (Tabela 2).

Tabela 2 - Modalidades de imagens explicativas segundo Duchastel e Waller (1979).

\begin{tabular}{|c|l|}
\hline Modalidade & \multicolumn{1}{|c|}{ Descrição } \\
\hline Descritiva & $\begin{array}{l}\text { Mostra o objeto como ele é, por exemplo, a fotografia de um } \\
\text { lobo. }\end{array}$ \\
\hline Expressiva & $\begin{array}{l}\text { Provoca impacto no leitor, como a imagem de ferimento ou uma } \\
\text { sequela de doença. }\end{array}$ \\
\hline Construtiva & $\begin{array}{l}\text { Esclarece como várias partes compõem um objeto ou nele se } \\
\text { encaixam (ex. esquemas dos constituintes de uma célula). }\end{array}$ \\
\hline Funcional & $\begin{array}{l}\text { Visualiza o desdobramento de um processo ou a organização de } \\
\text { um sistema (ex. representação da cadeia alimentar). }\end{array}$ \\
\hline Lógico-matemática & $\begin{array}{l}\text { São os gráficos de curvas utilizados em áreas científicas e em } \\
\text { muitos conceitos matemáticos. }\end{array}$ \\
\hline Algorítmica & $\begin{array}{l}\text { Apresenta a representação global do encadeamento de ações (ex. } \\
\text { um fluxograma). }\end{array}$ \\
\hline Data-display & $\begin{array}{l}\text { Compara dados visualmente, de forma rápida e fácil. Pode-se } \\
\text { utilizar este tipo para apresentar levantamentos estatísticos, } \\
\text { sociais e econômicos em gráficos de variadas formas: em barras, } \\
\text { linhas, colunas e outros. }\end{array}$ \\
\hline
\end{tabular}


Abordando-se mais diretamente as representações científicas, Kress e Van Leeuwen (2006) destacam três tipos de imagens: narrativas, analíticas e classificatórias.

Imagens narrativas "representam processos e ações que ocorrem ao longo do tempo", assim elas tentam contar uma história, portanto constituem uma sequência e direcionam a leitura. Normalmente, são ligadas por setas, como, por exemplo, uma imagem de ciclo de vida (MARTINS; GOUVÊA, 2001, p. 47).

A imagem classificatória é aquela que "organiza membros de uma mesma classe geralmente num arranjo simétrico de imagens do mesmo tipo ou na forma de árvores hierárquicas, representando taxonomias". Desse modo, elas oferecem um arranjo organizacional, permitindo a comparação das estruturas, como pirâmides de alimentos, árvores filogenéticas ou tabelas periódicas (MARTINS; GOUVÊA, 2001, p. 48).

Já as imagens analíticas estabelecem uma relação com as partes e o todo, mostrando os componentes de um sistema, por exemplo, um sistema imunitário, onde cada parte é identificada e nomeada. Essas imagens analíticas normalmente são representações simplificadas que destacam apenas os pontos que consideram relevantes (MARTINS; GOUVÊA, 2001).

\subsubsection{Imagem e Texto Escrito}

Muitos autores acreditam que a imagem não precisa ser acompanhada de um texto que lhe dará sentido. Em alguns casos, essa afirmação é válida, já que a imagem é também uma linguagem e, sozinha, pode trazer sentidos e significados. Por outro lado, mediante contextos tão diversos e pessoas de culturas tão distintas, uma legenda ou um texto explicativo auxiliarão o leitor a entender o sentido que o autor quer atribuir à imagem.

O texto pode direcionar o olhar para detalhes da imagem, fazendo o leitor considerar mais um significado do que outro. Em situações de aula, quem fará essa ponte entre imagem e significado que se quer extrair dela é a fala do professor ao apresentá-la para o grupo de alunos. Assim, a fala do professor é equivalente a uma legenda (SANTAELLA; NÖTH, 2008).

Segundo Barthes (1964, apud SANTAELLA; NÖTH, 2008, pg. 321) essa mediação pode ser por "ancoragem" e/ou "revezamento":

“(...) o sentido de uma imagem visual é ancorado pelo texto que o acompanha e pelo status dos objetos, tais como alimentos ou vestimentas, visto que os sistemas de 
signos necessitam 'da mediação da língua', que extrai seus significantes (na forma de nomenclatura) e nomeia seus significados (na forma de uso ou razão)".

Há diversos estudos que tratam sobre as relações semióticas entre a imagem e a linguagem em textos. Um deles foi desenvolvido por Kalverkamper (2005 apud, SANTAELLA; NÖTH, 2008), que evidencia três relações entre imagem e texto.

1-) Imagem inferior ao texto, apenas o complementando. Exemplos são as ilustrações que não tem a necessidade explícita de auxiliar o texto em um livro, de forma que, em outras edições, poderiam inclusive estar ausentes.

2-) Imagem superior ao texto, sendo mais informativa que o texto, portanto ela o domina. Exemplos são as imagens cuja ausência dificultaria muito o entendimento do texto.

3-) Imagem e o texto com a mesma importância, sendo assim estabelecida uma relação de complementaridade. A imagem, nesse caso, é integrada ao texto, dando uma relação de redundância e informatividade. Exemplos são os gráficos e textos que o explicam. Ambos trazem as mesmas informações, porém de formas diferentes. A ausência de um dos elementos dificultaria muito o entendimento dos dados.

Moles (1978, apud SANTAELLA; NÖTH, 2008, pg. 22) afirma que "a legenda comenta a imagem que, sozinha, não é totalmente entendida. A imagem ou figura comenta o texto e, em alguns casos, imagem comenta a sua legenda". Assim, a relação entre a imagem e o seu texto é íntima e variada. Essa relação entre imagem e texto, evidencia a concepção que o produtor do texto escrito ou falado tem da importância da imagem.

\footnotetext{
"Imagens mudam os textos, mas os textos, por sua vez, mudam as imagens. O que lemos ou ouvimos a respeito das imagens, a maneira como a literatura, a imprensa, a sinalização apropria-se delas, trituram-nas e apresentam-nas determina necessariamente a abordagem que fazemos delas" (JOLY, 2009:76).
} 


\subsubsection{Imagem Fotográfica}

Com a revolução industrial, houve a invenção das máquinas fotográficas, que captam as variações de luz sobre o objeto em um determinado momento. A palavra fotografia vem das palavras gregas "foto" que significa luz e "grafia" que significa escrita. Portanto, uma fotografia seria, em seu sentido original, uma escrita da luz.

"Há poucas dúvidas de que o estilo de vida contemporâneo tenha sido crucialmente influenciado pelas transformações que nele foram instauradas pelo advento da fotografia. [...] Quase tudo que acreditamos, a maior parte das coisas que sabemos, aprendemos, compramos, reconhecemos e desejamos, vem determinado pelo domínio que a fotografia exerce sobre a nossa psique. E esse fenômeno tende a intensificar-se" (DONDIS, 2000, pg. 9).

O surgimento da fotografia trouxe grandes transformações sociais, culturais e científicas, pois ela pode guardar a imagem de forma muito próxima ao real e continuar a existir mesmo que seu referente (algo ou alguém retratado na imagem) não exista mais. Assim, ela mudou nosso modo de interagir com o mundo, criando um conjunto de imagens que marcam nossa história de vida, tanto pessoal, como coletivamente, criando marcos históricos, culturais, artísticos, científicos, políticos e sociais. Passou a fazer parte da vida do cidadão pós-moderno e se tornou a melhor testemunha da verdade, dado a sua natureza físico-química, ganhando um grande status de credibilidade (RODRIGUES, 2007).

"Jean-Marie Schaffer destacou com muita clareza que o poder de convicção da fotografia, que se costumou a considerá-la como portadora de um pouco da realidade, provém do saber implícito ou não que o espectador tem sobre o gênese da imagem" (apud AUMONT, 1993, pg. 133).

Joly (2009) afirma que a imagem fotográfica, o vídeo e o filme são ícones puros, por serem consideradas imagens perfeitamente semelhantes àquilo que representa. Essa crença continua mesmo no mundo atual onde modificar uma fotografia é tão simples e rápido que podemos fazê-lo de forma amadora sem muitas dificuldades.

A autora também cita a importância das fotografias no meio científico e seu impacto na nossa sociedade: 


\begin{abstract}
"As imagens que ajudam a observar e interpretar os diversos fenômenos são produzidas a partir do registro de fenômenos físicos: o registro dos raios luminosos, na origem da fotografia, permite, por exemplo, que os satélites vigiem por teledetecção o aumento dos desertos no planeta, supervisionem e prevejam os fenômenos meteorológicos, que as sondas astronômicas filmem os planetas mais distantes e as microcâmeras, o interior do corpo humano.

Há muito tempo, esse já não é o único tipo de registro. $\mathrm{Na}$ medicina, por exemplo, graças à utilização dos raios $\mathrm{X}$, a radiografia conduz a explorações mais específicas. Outros tipos de procedimento coexistem, como o scanner e a utilização dos raios laser, ou as imagens de ressonância magnética. A ecografia, que registra as ondas sonoras, representa-as depois numa tela que as "traduz" visualmente" (pg. 24-25).
\end{abstract}

Desse modo, as imagens se tornaram parte de nossas vidas e cotidianos, capazes de ir além de nossa visão e ajudar-nos a registrar em nossa memória uma grande riqueza de detalhes, ampliando nossa capacidade mental de registrar e imaginar acontecimentos que ocorreram no passado (guerras, catástrofes e grandes festividades).

Hantzschel (2007) afirma que no século XIX a fotografia era aceita como uma reprodução perfeita da realidade e, apesar de hoje existirem meios de alterar as imagens fotográficas por meio da computação gráfica, muitos ainda acreditam fielmente nas imagens. Segundo Novellino (2007), passamos a utilizar as imagens fotográficas como provas documentais, sendo auxiliares de médicos e cientistas para dar validade a seus trabalhos e funcionando como um registro de dados.

Assim, essa crença de que a fotografia é uma cópia fiel da realidade é equivocada, pois o fotógrafo teve uma intencionalidade ao criar a imagem, um objetivo. Para enfatizalo, ele poderá utilizar diversos recursos, como proximidade, foco, jogo de luz e sombra, enquadramento, tonalidade, contraste, brilho, entre outros métodos. Assim, a imagem não é neutra, pois não está livre de opiniões e de valores, nela estão embutidos os desejos do fotógrafo. De forma semelhante, o observador da imagem fotográfica também tem seus conteúdos subjetivos, frutos de suas interações sociais e culturais com o mundo que irão influenciar sua leitura/interpretação visual, como abordaremos com mais detalhes posteriormente. 


\title{
3.2.6 Polissemia da Imagem
}

\begin{abstract}
“[...] nossos modos de leitura das imagens também trabalham sob o implícito da transparência, sob o pressuposto de que o que vemos numa imagem é o que todo mundo vê. Se a imagem é a imagem de um objeto, se há quase uma intercambialidade total entre imagem e objeto, se há um esquecimento do caráter interventor e de construção da imagem, o efeito discursivo disso é um modo de leitura como transparência total. Linguagem e mundo se equivalem completamente na imagem" (SILVA et. al. 2006, pg. 219).
\end{abstract}

A linguagem imagética, assim como as demais linguagens, é simbólica e, portanto, sua leitura é influenciada por aspectos socioculturais, como já discutimos. "Ou seja, é preciso entender a representação imagética enquanto produto cultural de uma sociedade, com múltiplas diferenciações entre os diversos grupos sociais” (LOPEZ, 2000, p. 44). Dessa forma, para uma mesma imagem, sempre haverá múltiplas leituras, devendo-se superar a falsa crença que a imagem fala por si mesma e que ela tem um significado único.

Aumont (1993), com base em suas pesquisas, destaca que a visão não é de forma nenhuma um instrumento neutro, que transmite fielmente os dados, pois o olhar tem uma intencionalidade e finalidade, fazendo inconscientemente, uma seleção de elementos, influenciada pela atenção e pela busca visual. A atenção visual se divide em duas: (1) central, aquela que focaliza aspectos importantes do campo visual; e a (2) periférica, é mais vaga e relaciona-se aos fenômenos novos da periferia do campo (AUMONT, 1993).

A busca visual é o "processo que consiste em encadear diversas fixações sucessivas sobre uma mesma cena visual, a fim de explorá-lo em detalhes”. Porém, os pontos e o ritmo de fixação do olhar variam de observador para observador, dependendo de seu interesse (AUMONT, 1993, pg. 60).

Assim, profissionais de diversas áreas do conhecimento irão olhar para a mesma imagem e cada um terá uma busca visual diferente, o que irá influenciar sua interpretação. Após o processo de globalização a imagem passou a ocupar um espaço cada vez maior. Contudo, não se pode generalizar a interpretação dada a uma determinada imagem. Como destacamos no item 3.1 da presente dissertação, cada indivíduo é um ser social e histórico, fruto de sua realidade cultural, social e histórica.

Cada indivíduo carrega uma bagagem cultural diferente, que influencia sua maneira de pensar, sentir e interpretar a realidade que o cerca. Assim, todas as pessoas são únicas, já que cada uma possui uma história, seu modo de fazer, ser e pensar. Cada um de nós 
carrega consigo o seu mundo subjetivo, fruto de sua história cultural, pessoal, social e transcentralidade, criadas a partir de uma construção individual (HENGMÜHLE, 2000).

Desse modo, cada indivíduo, ao ver uma imagem, irá ter uma experiência interpretativa única. O dito popular afirma que "uma imagem diz mais que mil palavras!". Porém, essas mil palavras não serão as mesmas para todos.

Para o semioticista Barthes (1990), toda imagem é, por natureza, polissêmica. Na imagem, há uma cadeia de significados, denotativos e conotativos, que são escolhidos pelo observador. Ele opta por um significado em detrimento de outro, ao observar mais cuidadosamente alguns detalhes do que outros, influenciado por sua busca visual.

Rossi (2009) explica que quando o observador/leitor está analisando uma imagem se defronta com um quebra cabeça, no qual ele tenta encontrar um significado conceitual ou estético. Assim "ao ler uma imagem, fazemos perguntas a ela, mesmo quando não sabemos que estamos interpretando. Dialogamos, implicitamente, com ela, buscando compreendê-la" (pg. 36). Uma imagem possui diferentes mensagens, dependendo da interpretação do observador/leitor da imagem. Raramente uma imagem transmite uma mensagem única a todos que a observam.

Pensando-se especificamente no Ensino de Ciências, podemos inferir que o professor, ao explorar uma imagem, deve ter claro aquilo que quer destacar para o estudante visando sua melhor aprendizagem dentro do objetivo educacional traçado pelo professor. 


\subsection{Alfabetização Visual}

“[...] O alfabetismo significa que um grupo compartilha o significado atribuído a um corpo comum de informações. [...]”. (DONDIS, 2000, pg. 3). Assim, uma alfabetização visual é entendida como um modo de despertar a inteligência visual e a relacioná-la com experiência visual já existente, de modo que o indivíduo desenvolva habilidades que serão necessárias, para a compreensão das mensagens visuais presentes na sociedade da qual está inserido (DONDIS, 2000).

Como foi dito anteriormente, estamos constantemente rodeados de imagens. Segundo Jameson (1994), somos bombardeados por mais de mil imagens por dia, o que nos leva, muitas vezes, a consumi-las sem critérios e reflexão. Essa situação também nos faz confundir o que é imaginário e o que é real, bem como as experiências específicas da imagem das demais experiências.

Pesquisas como as de Silva (2004), Bouro (2002), Cassiano (2002), Martins (1997), Amador e Carneiro (1999), entre outras, mostram que a leitura das imagens precisa ser aprendida, caso contrário, o indivíduo corre o risco de ser, como já mencionado, um mero "consumidor de imagens", não reflexivo. O caráter polissêmico das imagens torna esse aprendizado ainda mais importante. Nesse processo de ensino-aprendizagem de leitura de imagens, o professor apresenta o papel fundamental de mediador. Cabe a ele direcionar o olhar do aprendiz, bem como auxiliá-lo a superar a crença de que a imagem é uma realidade absoluta. Tais aspectos das imagens também são muito importantes nas aulas de Ciências, devendo ser considerados com especial cuidado pelos professores.

Não basta acreditar que a visualização rápida de uma imagem levará ao entendimento de um conceito, afinal nem sempre o que é evidente na leitura da imagem, para o professor também é para o aluno. Cabe ao professor guiar o olhar do aluno e, a partir do diálogo, chegar a uma leitura em comum da imagem (SILVA et. al. 2006).

Geralmente, a escola no processo de alfabetização verbal, deixa de lado a experiência visual da criança, como se ambas as linguagens fossem separadas ou até mesmo como se as imagens não constituíssem em si mesmas uma linguagem própria. Se analisarmos os livros infantis veremos uma vastidão de imagens de todos os tipos, cores e tamanhos. Porém, geralmente, conforme a criança é alfabetizada verbalmente, menos imagens aparecem nos livros, como se as mesmas fossem desnecessárias e apenas estivessem nos livros infantis devido à falta da capacidade de leitura verbal da criança. 
Segundo Kress e Van Leeuwen (2006), somente nos primeiros anos de escolaridade as crianças são incentivadas a produzirem imagens para ilustrar seus textos, e tais produções são vistas apenas como uma forma de auto expressão da criança, algo que ela sabe fazer naturalmente e que não deve ser ensinado. No Ensino Fundamental, esse enfoque é alterado gradativamente dando mais destaque a linguagem escrita. Os autores comentam que as imagens em livros didáticos também diminuem e se tornam mais técnicas e pontuais. As imagens são mais presentes em disciplinas como Ciências e Geografia. Já nas disciplinas ligadas às áreas humanas (História, Inglês, Português, Filosofia), as imagens são praticamente inexistentes e assumem apenas a função de decoração.

Fora da escola, a utilização das imagens segue em um caminho inverso ao da escola. Vemos um uso intensivo de imagens, não apenas em produtos ou livros para crianças, mas também na mídia em geral, jornais, revistas, CD-ROM's, sites e em materiais de cunho publicitário. Nesses meios de comunicação, passou a dominar o sistema multimodal de linguagem, mesclando vários sistemas linguísticos: texto, áudio, imagens, animações, geralmente os meios visuais estão em maior destaque (KRESS; VAN LEEUWEN, 2006).

Dondis (2000) afirma que ainda falta rigor e objetivos definidos para o uso das imagens em aula. Falta ao professor ir além da função ilustrativa da imagem e incorporar uma postura menos passiva mediante da sua leitura.

\footnotetext{
"Uma das tragédias do avassalador potencial do alfabetismo visual em todos os níveis da educação é a função irracional, de depositário da recreação, que as artes visuais desempenham nos currículos escolares, e a situação parecida que se verifica no uso dos meios de comunicação, câmeras, cinema e televisão. Por que herdamos, nas artes visuais, uma devoção tática ao não-intelectualismo? O exame dos sistemas de educação revela que o desenvolvimento de métodos construtivos de aprendizagem visual são ignorados, a não ser no caso de alunos especialmente interessados e talentosos" (DONDIS, 2000, pg. 17)
}

Devemos superar o inatismo visual e passar a tomar decisões mais conscientes ao interpretar uma imagem, que não sejam ligadas somente ao senso comum ou às preferências pessoais, ir além da decodificação rápida, superficial e sem critérios, dando-se conta dos inúmeros conceitos e da complexidade da tarefa (DONDIS, 2000). 
Com os avanços da tecnologia das telecomunicações e das mídias, as imagens ganharam um novo status social, tendo uma atenção principalmente do ramo da publicidade, onde há um grande investimento de dinheiro, energia e talento na produção de imagens. Elas contêm mensagens que influenciam mais do que textos verbais e segundo Rossi (2009), conseguem ditar o que devemos pensar, sentir, fazer, necessitar e desejar e assim, moldam nossos pensamentos e condutas. A publicidade passou a utilizar um número cada vez maior de imagens e acabamos sendo obrigados a consumi-las. Dessa forma, precisamos nos conscientizar sobre quais as formas de utilização de imagens e perceber o que elas pretendem nos impor, para nos tornarmos capazes de escolher no que iremos seguir e acreditar (ROSSI, 2009). Para superar a passividade em relação à leitura de imagens e conseguir lê-las de forma crítica e reflexiva, não sendo drasticamente influenciados por elas, temos que nos dar conta de como realizamos essa leitura compulsória e quais as convenções históricas e culturais que estão interiorizadas, como por exemplo, relacionar à imagem de uma pomba a ideia de paz (JOLY, 2009).

O processo de alfabetização na linguagem visual não está intimamente relacionado ao da linguagem verbal, mesmo que ambos trabalhem em paralelo, já que os métodos utilizados na leitura e escrita de textos verbais não são os mesmos utilizados na linguagem visual. Contudo, para Dondis (2000), na linguagem visual assim como na verbal, existem unidades elementares, que podem ser comparadas com o abecedário da linguagem escrita. Essas unidades são essenciais para o processo de alfabetização visual e devem ser internalizadas em nosso consciente e inconsciente, a fim de que possamos acessá-las rapidamente, para que possamos ler/interpretar as imagens que nos cercam diariamente de forma mais crítica. Mas essas unidades não podem ser aprendidas de forma tão rápida quanto o abecedário, pois a informação visual é mais complexa e rica em definições e significados, precisamos ficar atentos à forma como interpretamos as imagens e quais os passos que realizamos para essa leitura. Assim, vamos paulatinamente, nos apropriando dessas unidades básicas e tornando-as conscientes a nós mesmos (DONDIS, 2000).

O método de composição e leitura das imagens é intensamente ligado a fatores psicológicos da percepção humana, pois a consciência visual não é somente baseada na visão, mas também nos demais sentidos de forma integrada e dinâmica. Muitas pessoas, por não compreenderem ou por não terem conhecimento desse método de leitura visual, justificam tal carência por uma falta de "talento em leitura de imagens". Outras pessoas já 
pensam que a mensagem visual é imediata e igual a todos de forma quase instantânea (DONDIS, 2000).

Nas escolas, podemos notar esses dois tipos de visões de leitura de imagens. Muitos professores não se acham capazes de entender mensagens visuais e tentam utilizar imagens o menos possível, pois não as consideram importantes. Outro tipo de professor é aquele que usa diversas imagens sem explorá-las, porque, para ele, a mensagem delas é tão clara que não existe ninguém que não irá captá-la e entendê-la de imediato. Dondis (2000) afirma que ambas as visões são equivocadas, pois do mesmo modo que a linguagem verbal deve ser aprendida e melhorada no decorrer dos anos, a capacidade visual não é algo estático, para a qual ou você nasce com esse "talento" ou não, mas sim uma habilidade que pode ser adquirida com estudo e esforço. Quando nos tornamos alfabetizados visualmente, desenvolvemos nosso próprio senso crítico sobre as imagens. O alfabetismo visual permite o domínio de modismos e o controle de seus efeitos, bem como uma compreensão mais fácil de todos os significados das formas visuais (DONDIS, 2000).

Já que a alfabetização visual é tão discutida, poderíamos falar então sobre uma gramática da imagem? Lucia Santaella e Winfried Nöth, em seu livro "A imagem: cognição, semiótica e mídia", tentam responder essa pergunta em seu estudo fundamentando-se nos pensamentos de diversos autores (SANTAELA; NÖTH, 2008).

Existem autores contrários à existência de uma gramática das imagens. Segundo Benveniste (1969), para que houvesse uma verdadeira gramática da imagem, deveria haver critérios pré-estabelecidos, tal como um repertório limitado de signos e regras de ordenação das unidades mínimas. Em sua visão não há uma gramática definida para a leitura/interpretação de imagens (apud SANTAELA; NÖTH, 2008).

Contudo, há autores que acreditam na existência de uma estrutura ordenada para a leitura de imagens. Dondis (2000) afirma que há uma sintaxe da imagem, com padrões de criação e elementos básicos que podem ser aprendidos. Para ela, haveria unidades elementares que, combinadas, formariam a mensagem da imagem. Vários autores tentam nomear o que seriam essas unidades básicas, a fim de criar as bases da gramática da imagem. Uma das tentativas de sistematizar as unidades elementares foi desenvolvida por Bertin (1967) que as divide em: tamanho, grau de claridade, padrão, cor, direção e forma.

Outros autores ainda propõem classificações para como a imagem é interpretada. Rossi (2009), baseado em Freeman e Sanger (1995), separa a interpretação por níveis de entendimento, sendo o mais básico as relações imagem-mundo, seguido pela imagem- 
artista e por último imagem-leitor. Nem todos os indivíduos chegam ao nível mais alto de interpretação, tais níveis são influenciados pela vivencia e pelo exercício interpretativo.

No primeiro nível (Imagem-Mundo) se acredita que o artista aproveita-se da realidade para criar algo. Assim, a imagem é vista como a própria realidade, e o artista não tem nenhuma influência sobre sua criação.

No segundo nível (Imagem-Artista), o indivíduo começa a pensar na intencionalidade do artista, ou seja, na mensagem que ele pretendia transmitir com a imagem. Assim, ela deve ser "decifrada" pelo leitor, que irá tentar entender qual é a mensagem da imagem (como se só houvesse uma resposta possível e o artista a apresenta com total clareza, existindo uma forte necessidade de um texto que a explique). $\mathrm{O}$ artista não é visto como um ser sócio histórico influenciado pela sua sociedade e cultura, principalmente na construção de imagens científicas (ROSSI, 2009).

No nível Imagem-Leitor, a percepção passa a um sentido mais amplo, onde se deixa de determinar precisamente as intenções do artista. Há um reconhecimento da possibilidade de múltiplas interpretações, havendo em uma única imagem mais de um significado possível para seus elementos. Cabe ao leitor deduzir tais significados, independente do que o artista quis comunicar. Nessa fase, o leitor tem necessidade uma habilidade cognitiva, que permita refletir sobre si mesmo, havendo um abandono da crença de que se analisarmos objetivamente a imagem e seus elementos, iremos conseguir decifrar as intenções do artista, passando a adotar uma ideia de leitor mais ativo na construção de significados e o sentido irá ser dado pela subjetividade de cada leitor (ROSSI, 2009).

É importante destacar que trabalhar com imagens em uma disciplina que não está necessariamente envolvida com a área de artes visuais não tem necessariamente o objetivo de levar os alunos a níveis mais altos de interpretação de imagens, mas sim trabalhar com as imagens de um modo mais crítico visando no mínimo que, o aluno supere o estágio mundo-artista, no qual ele acredita fielmente nas imagens e as veem como cópias da realidade, sem a possibilidade da imagem ter sido manipulada pelo artista. 


\subsection{Imagem como Recurso Didático}

Iniciamos nosso texto relacionando o ser social, a linguagem e a imagem. Passamos à discussão sobre a natureza e classificações das imagens, seguindo com a abordagem sobre como as imagens estão presentes no nosso cotidiano e como é importante aprender a ler suas mensagens de forma crítica para não sermos manipulados por elas. Agora, passaremos a focar como essas imagens chegaram a se tornar recursos didáticos e como são utilizadas em sala de aula ou em livros escolares, o que nem sempre ocorre apropriadamente, podendo até influenciar na aquisição de conceitos errôneos por parte dos alunos.

As imagens são importantes ferramentas didáticas porque possibilitam uma maior interação com o texto, além de muitas outras funções, como ampliar a capacidade de comparar, descrever, sintetizar, enumerar e discriminar (MARTINS; GOUVÊA, 2001). Assim auxiliam na aprendizagem, contudo não levam obrigatoriamente à compreensão do conceito. Cabe ao professor direcionar o olhar dos alunos para a imagem e ajudá-los a atribuírem significados para o que estão vendo e qual a relação da imagem com o conceito (SILVA et. al. 2006).

O uso de imagens no processo de ensino-aprendizagem é defendido por muitos autores, tais como Perales e Jiménez (2002), Martins e Gouvêa (2001), Casiano (2002) e Jiménez (1997), como sendo uma ferramenta didática de extrema importância para a comunicação e compreensão dos conceitos, principalmente os conteúdos científicos.

Perales e Jiménez (2002) destacam que as imagens prendem a atenção do aluno, facilitam a compreensão do texto e despertam interesse para a aprendizagem. Elas ajudam o aluno a construir um quadro de representação de conceitos e ideias, mesmo que tais conceitos sejam bastante abstratos e que sua conceitualização dependa da própria visualização (MARTINS; GOUVÊA, 2001).

A pesquisa realizada por Cassiano (2002) mostra que cerca de dois terços das imagens em livros didáticos de física são imprescindíveis na explicação destes conceitos.

A imagem possibilita ao professor trazer para a sala de aula algo que seria impossível na realidade. Por exemplo, não podemos trazer uma baleia Jubarte para dentro da sala de aula, mas sim uma imagem ou um vídeo. No entanto, o professor sempre corre o risco de que o aluno acredite que a baleia Jubarte mostrada pela imagem é exatamente igual a vista no mundo real. 
Assim, acreditamos que cabe aos professores trabalhar com a imagem de modo a deixar claro para seus alunos que, mesmo ela sendo uma fotografia, não é o animal em si, mas sim uma representação do animal, destacando as diferenças entre a imagem e o animal real, tal como tamanho, coloração, entre outras características.

Acreditamos que o professor, ao não trabalhar dessa forma, corre o risco de que seus alunos estejam tomando as imagens como verdades absolutas. Por exemplo, ao apontar para um diagrama e dizer: "essa é a uma cadeia alimentar", seu aluno pode entender o conceito como sendo o próprio diagrama.

A Ciência tem um simbolismo próprio ao apresentar imagens, que pode ser claro para o professor, mas nem sempre é para os alunos. Um exemplo seria o esquema de cores em um sistema circulatório, no qual traços azuis representam as veias e os traços vermelhos representam as artérias. Porém, se essa forma de representação não for trabalhada com os alunos, eles poderão ter a falsa ideia de que a diferença entre os tipos de vasos sanguíneos realmente é a cor (MARTINS; GOUVÊA, 2001).

Silva e Cavassan (2003) apontam que livros que utilizam apenas fauna e flora estrangeiras podem levar o aluno a pensar que a natureza nativa é igual à mostrada nesses livros ou que os organismos do Brasil não são tão importantes, já que nem aparecem nos livros. Outro ponto citado pelos autores é a relação entre imagem e texto. A Figura 1 ilustra tal relação. Ela aparece acompanhada do texto: "observando a imagem compare, dois seres vivos: uma árvore e um cachorro", transmitindo uma impressão que o menino não seja um ser vivo, já que ele nem é mencionado no texto.

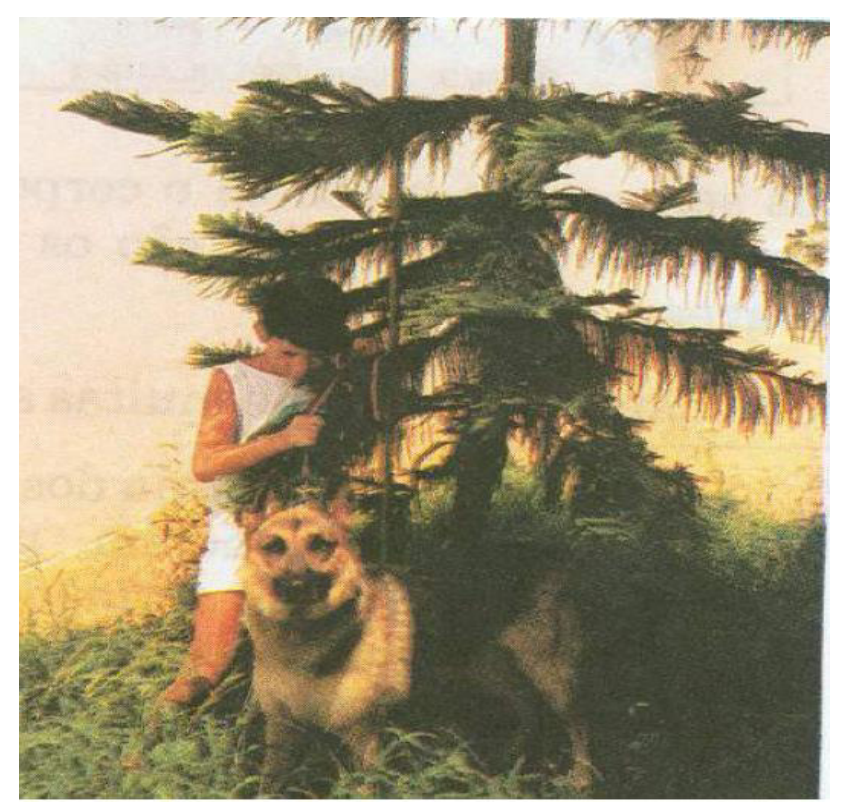

Figura 1- Menino, árvore e cachorro (imagem retirada da pesquisa de Silva e Cavassan, 2003). 
Assim, os professores devem enfatizar que a imagem é apenas uma representação. As imagens devem ser trabalhadas pelos professores para que fique claro seu objetivo, os detalhes que se quer enfatizar, a escala e a mensagem que ela procura transmitir, já que de uma mesma imagem podem surgir múltiplas interpretações.

Nesse sentido, cabe bem a afirmação de Sgarbi (2001, p.123-124): “Uma imagem não vale mais do que mil palavras [...] uma imagem vale uma imagem", pois ela necessita ser interpretada, sendo para isso importante que os alunos aprendam a ler as imagens.

Sem dúvida, alfabetizar visualmente nossos alunos é uma tarefa complexa, já que uma única imagem abre portas para milhares de interpretações possíveis. Martins (1994, p. 30) enfatiza que é “... preciso considerar a leitura como um processo de compreensão de expressões formais e simbólicas, não importando por meio de que linguagem”.

\footnotetext{
“A compreensão das imagens não é imediata, e seu uso no contexto pedagógico da sala de aula exige que o professor saiba como fazê-lo, ou seja, ele pode ajudar o aluno a perceber, entre outros aspectos, os elementos constitutivos da imagem em questão" (SILVA, et. al., 2006 p. 221).
}

Outro cuidado que o professor pode ter ao trabalhar com imagens é o de comentar, mesmo que brevemente, o contexto de criação da imagem, uma vez que toda imagem é criada por alguém e com uma intenção. "A produção de imagens jamais é gratuita, e, desde sempre, as imagens foram fabricadas para determinados usos, individuais ou coletivos" (AUMONT, 1993, pg. 78). Desse modo, o produtor da imagem tinha um objetivo ao criar a imagem como, por exemplo, destacar partes do animal que queria enfatizar. O professor deve deixar claro qual o enfoque que quer dar para cada imagem, direcionando assim o olhar do aluno.

Como já discutimos, as imagens são simbólicas, extremamente complexas e subjetivas. Assim sendo, cada aluno pode ter diferentes interpretações para a mesma imagem. Isso ocorre porque nossa busca visual é influenciada por nossos conceitos culturais e nossas escolhas inconscientes. Até mesmo o ato de ver é influenciado por tais fatores socioculturais. Por exemplo, os esquimós, por terem uma experiência muito rica com a cor branca, conseguem distinguir diferentes tons de branco (AUMONT, 1993). 
Assim, voltamos à questão da polissemia das imagens, pois nela há várias vozes e vários caminhos interpretativos e, em uma situação de ensino-aprendizagem, cabe ao professor destacar qual o enfoque dará a cada imagem apresentada.

A partir de todas as reflexões apresentadas, emergem as questões: "Mas os professores estão preparados para lidar de forma adequada com a leitura de imagens? Essa temática é discutida em sua formação, seja inicial, seja continuada?”.

\footnotetext{
"É importante que a formação inicial e continuada de professores leve em conta este papel mediador do professor, pois ela é responsável pela sua constituição. Embora a literatura forneça inúmeras sugestões e derive implicações para a formação de professores no tocante ao uso de imagens (COLIN et al., 2002), não encontramos pesquisas sobre como o trabalho de formação, seja inicial, seja continuada, intervém ou pode intervir na constituição deste papel do professor" (SILVA, et. al., 2006, pg. 220).
}

Como tem se percebido, os professores muitas vezes não exploram a imagem de forma adequada. Ao contrário, as imagens muitas vezes são utilizadas como meras ilustrações do texto escrito ou uma distração para o aluno. Mesmo em muitos livros didáticos, as ilustrações aparecem como meras decorações, podendo até atrapalhar a aprendizagem, dando aos alunos falsas concepções da realidade (BOURO, 2002).

Diante do cenário apresentado, julgamos pertinente discutir alguns aspetos gerais sobre a formação de professores, o que será abordado no próximo item. 


\subsection{Formação de Professores}

"Se é com seres humanos que vamos lidar, então devemos buscar a essência ou a natureza constitutiva desses seres humanos que se colocam diante de nós" (HENGMÜHLE, 2007, pg.33).

Iniciamos este item apresentando alguns aspectos gerais das discussões atuais sobre formação inicial de professores de Ciências para atuarem no Ensino Básico. Apresentamos ainda uma breve introdução sobre a formação dos docentes universitários formadores de tais professores. Optamos por tal recorte devido a esta pesquisa focar-se justamente em um aspecto (utilização de imagens) da atuação desses sujeitos (docente universitário).

Atualmente, aumentou consideravelmente a preocupação com questões relacionadas à formação de professores em todos os níveis, o que se evidencia pelo grande aumento de livros, artigos em periódicos, dissertações, teses e eventos sobre o tema (SANTOS, 2002).

Os debates sobre o assunto estão trazendo para o âmbito das escolas novas ideias e reflexões, principalmente relacionadas à experiência docente, uma vez que é indiscutível a necessidade da aprendizagem e reflexão sobre a prática na formação docente, seja ela inicial ou continuada.

Para Carvalho e Pérez (2001), a docência "se dá na prática", de modo que, a experiência é a principal base para a formação docente, afinal não adianta o professor ter muito conhecimento teórico e nenhum conhecimento prático. Assim, nos anos iniciais da atuação docente o professor começa a se construir com base em suas primeiras experiências ou como aluno ou como professor.

Lippe e Bastos (2008) afirmam que "a formação docente não pode ser reduzida ao domínio de conteúdos e técnicas a serem utilizadas em futuras práticas pedagógicas, transformando os professores em meros executores de tarefas". Sendo assim, um papel importante da formação inicial seria dar suporte para essa primeira formação prática, oferecendo ao futuro professor momentos de prática antes da sua inserção na escola, essas experiências deveriam ser planejadas e analisadas, buscando um aprimoramento da própria prática. Autores como Tardif (2004), Garcia (1999) e Perrenoud (2001) destacam que os 
primeiros contatos com o ambiente escolar são fundamentais para a formação docente. Lippe e Bastos (2008) afirmam que o professor, em seus primeiros anos de docência, se depara com uma série de dificuldades como: excesso de carga horária, salas de aulas superlotadas, falta de infraestrutura e de matérias e equipamentos, alunos desinteressados e indisciplinados, violência, etc. Assim, é fundamental que tais temáticas permeiem os cursos de Licenciatura.

Um professor iniciante terá contato com uma infinidade de novas situações que a teoria não pode prever. Tais situações necessitam, muitas vezes, de decisões e atitudes imediatas, sobre as quais nem sempre é possível que o professor reflita muito antes da ação. A prática docente tem como principal função a ordenação de teorias e técnicas na resolução de problemas enfrentados diariamente pelos professores, já que o cotidiano escolar é repleto de ações difíceis de serem descritas de forma precisa e a resposta dada a cada situação é construída pela prática docente (SANTOS, 2002).

Essas respostas formam o que Perrenoud (2001) chama de "habbitus", que são seu repertório das respostas imediatas a problemas comuns. Essas decisões são feitas de forma rápida e sem uma reflexão mais profunda, o que desencadeia escolhas que nem sempre refletem sua postura didática e sua filosofia de ensino, mas que estão associadas ao seu repertório de atitudes espontâneas, muitas vezes trazidas de outros contextos onde ele ainda era um aluno. Tais atitudes são internalizadas de forma tão intensa que a ação se desencadeia de forma quase automática, o que não é o desejável. Por esse motivo, Perrenoud (2001) defende a importância de uma reflexão sobre a própria prática docente. Essa reflexão também é esperada para os professores universitários (como os sujeitos da presente pesquisa) e devem incluir, dentre vários temas, a utilização de imagens.

Há ainda falhas graves na formação inicial dos professores de Ciências, dentre elas podemos citar as apresentadas por Carrascosa (2001) e Menezes (2001) levantadas pelo projeto IBERCIMA (Programa Ibero-Americano de Ensino das Ciências e da Matemática no Nível Médio), organizado pelos estados ibero-americanos para a Educação, a Ciência e a Cultura (OEI) e pelo Ministério de Educação de Ciências da Espanha, com objetivo de criar um panorama na atual da formação de professores de Ciência:

1-) Baixa qualidade da formação inicial dos professores, pois muitos cursos na área de ensino de ciências tem um enfoque maior nos conteúdos disciplinares em detrimento aos de cunho pedagógicos e grande parte dos pós-graduados da área só apresentam interesse em área da ciência pura, sem se importar com os métodos de ensino; 
2-) Desvinculação entre os cursos de formação inicial e os de cursos de formação contínua - não há diálogo e integração entre as duas etapas de formação e assim não há uma continuidade na formação do professor;

3-) Existência de poucos cursos de formação docente contínua, dando aos professores poucas opções para sua formação;

4-) Desvinculação entre os grupos que querem trabalhar com métodos mais inovadores no ensino de ciências e os demais professores que trabalham com as disciplinas de ciências;

5-) Ausência de ações conjuntas entre os ministérios da Educação e demais Instituições de formação contínua de médio e longo prazo para professores de ciências;

6-) Dificuldades de se formar grupos estáveis, envolvendo professores das escolas secundárias e professores universitários;

7-) Dificuldade de produzir materiais educacionais em larga escala ou mesmo matérias que atendam mais aos interesses das editoras;

8-) Distâncias geográficas que dificultam o acesso de professores aos cursos de formação permanente;

9-) Número elevado de turmas e da elevada carga horária de trabalho por semana, não restando tempo para os professores se dedicarem a um curso de formação, nos quais devido ao baixo salário os professores acabam se vendo obrigados a completar sua jornada com mais turmas;

10-) Há ainda nas escolas professores sem habilitações específicas para o ensino de ciências, essa carência de professores nas áreas de ciência e matemática, não é somente um problema dos países ibero-americanos, mas também de países mais desenvolvidos como os Estados Unidos como relatam Ingersoll e Perda (2010) em sua pesquisa;

11-) Falta de recursos econômicos para incentivar ou mesmo desenvolver cursos de formação contínua;

12-) Existem poucas revistas especializadas em ensino de Ciências e a maior parte das existentes se limita a discutir temas relacionados apenas a educação;

13-) Muitos cursos se restringem em discutir temas somente relacionados à educação, como psicologia da educação, sem relacionar-se diretamente a didática de ciências;

14-) Em muitos países, é reduzido o número de trabalhos de investigações científicodidáticas realizadas por professores em serviço. 
O Projeto IBERCIMA aponta ainda alguns aspectos que foram definidos como essenciais para a formação de professores (CARRASCOSA, 2001), destacado à seguir.

1-) Conhecer a matéria a ensinar - esta é a primeira necessidade formativa, de modo que os professores não se tornem tão inseguros a ponto de se tornarem dependentes dos livros didáticos ou inseguros, ao ponto de terem medo de criarem novas formas de trabalhar com o conteúdo de modo mais inovador:

a) O professor também necessita ter uma formação inicial envolvendo outras áreas do conhecimento como história e filosofia das ciências, para que o professor se sinta mais à vontade para trabalhar de forma interdisciplinar;

b) Ter conhecimentos de cunho didático-pedagógico - não basta ter conhecimento do conteúdo disciplinar para desenvolver um ensino de qualidade, também é necessário ter conhecimentos sobre como se ensina e como se aprende, sobre metodologias e estratégias de ensino, natureza do trabalho científico, para não ficar somente culpando os alunos ou a causas externas aos fracassos escolares, ignorando o papel que desempenha o tipo de ensino e as expectativas do professor;

c) Conhecer as estratégias do trabalho científico, como já foi mencionado por Peréz e Carvalho (2001), no item 2 de seu levantamento;

d) Conhecer as interações Ciência/Tecnologia/Sociedade;

e) Estar atento às atualizações do saber, mostrando uma visão de ciência mais dinâmica;

f) Saber selecionar conteúdos adequados, assuntos acessíveis e de interesse dos alunos.

2-) Concepções prévias dos professores sobre o ensino e aprendizagem das ciências- há alguns conceitos prévios sobre ser professor que atrapalham a atividade docente, entre eles estão:

a) Ensinar é fácil: acredita-se que apenas com os conhecimentos teóricos é possível ensinar, ou que basta seguir uma receita pronta;

b) O professor é a fonte de todo o conhecimento e uma autoridade indiscutível na sala de aula;

c) É impossível avaliar inovações no ensino graças a grande extensão de conteúdos exigidos no currículo ou pela falta de materiais mais inovadores; 
d) O fracasso do aluno é atribuído apenas a ele mesmo, sejam motivos intelectuais, sociais ou de gênero.

3-) Ter suporte para a prática - muitas vezes professores recém-formados por falta de alternativas mais concretas e experiências vivenciadas no papel de professor, acabam reproduzindo o modelo de professor que tiveram em seu período como aluno, mesmo que tais métodos não fossem considerados boas alternativas pedagógicas na época;

4-) Criar atividades construtivas - criar possibilidades de que os alunos construam seus conhecimentos por meio de atividades contendo situações problemáticas, que necessitem de tomadas de decisões pelo aluno, com construção de hipóteses, estratégias de resolução, teste das hipóteses, métodos de análise e etc.;

5-) Saber orientar o trabalho dos alunos - apresentar a pesquisa a ser desenvolvida, facilitar a constituição do trabalho e a busca por informações, criar um bom clima de trabalho e orientar o trabalho em grupo;

6-) Saber avaliar - A avaliação deve ser baseada em todo o processo, não somente nos resultados finais, uma avaliação que englobe todas as habilidades, atitudes e saberes, não seja comparativa e classificatória, o que Hoffmann (1993) chama de uma avaliação mediadora.

Em nosso país, críticas vêm sendo realizadas ao processo formativo de professores. Os autores Pérez e Carvalho (2001) criticam o sistema perdurado nas últimas duas décadas, que é caracterizado pelas licenciaturas curtas, que visam preparar professores de Ciências da Natureza, Biologia, Geologia, Física, Química ou Matemática, em apenas três anos.

Mediante todas essas dificuldades formativas, destacamos ainda a, necessidade de um investimento na formação dos docentes universitários formadores dos futuros professores de Ciências, pois o professor se espelha em suas experiências como aluno para criar seu método de atuação docente. Assim, cabe pensar a dupla responsabilidade que tais docentes assumem, por que, além de ensinar os conteúdos de forma adequada, acreditamos que eles também estão exemplificando posturas e métodos de como "ser um professor". Mesmo que não tenham isso em mente, seus alunos estão observando suas atitudes e inconscientemente incorporando tais atitudes em seu repertório de representações mentais.

Justifica-se a forte preocupação a respeito da docência universitária, pois, apesar de muitos terem uma ampla experiência em suas áreas específicas de atuação, ou mesmo, um rico embasamento teórico, quando entram em sala de aula, se encontram despreparados para enfrentar os problemas relacionados ao ensino-aprendizagem, ou com a complexa 
rede de inter-relações pessoais existentes, ou ainda, relacionados com a vasta diversidade de alunos em sala de aula (JANUARIO, 2007).

Como há poucos cursos específicos para a formação do professor universitário, este deve aprender sozinho como atuar, mediante associações intuitivas (com base em seus conceitos prévios de como se ensina, ou baseado em sua experiência como aluno) ou mesmo observando a rotina dos demais docentes. Januario $(2007$, pg.8) citando Pimenta (2002) afirma que:

\footnotetext{
"Geralmente os professores ingressam em departamentos que atuam em cursos aprovados, em que já estão estabelecidas as disciplinas que ministrarão. Aí recebem ementas prontas, planejam individualmente (...) os resultados obtidos não são objetos de estudo (...) não recebem qualquer orientação sobre processos de planejamento (...). Como se percebe, a questão da docência na universidade ultrapassa os processos de sala de aula, pondo em discussão as finalidades do ensino da graduação, o que tem sido reconhecido em diferentes países."
}

Talvez por falta de conhecimentos das discussões educacionais, muitas vezes o professor universitário que não está ligado diretamente com as disciplinas pedagógicas apresenta uma visão mais tradicional de ensino, visando à formação de "tecnicistas". Tais aspectos estão implícitos não somente na postura dos professores universitários, mas também na proposta curricular dos cursos de formação inicial, levam os alunos, muitas vezes a acreditarem, que alguma disciplina irá lhe oferecer uma "receita pronta" de como ministrar suas aulas, como comprova a pesquisa de Lippe e Bastos (2008), que em uma entrevista com licenciandos de um curso de ciências biológicas, obtiveram $69 \%$ dos alunos do primeiro ano afirmando que esperavam uma receita pronta nas disciplinas pedagógicas, e nos dois últimos anos essa taxa foi de 67,5\%. A postura dos professores universitários acaba, de certo modo, reforçando essa falsa crença no professor em formação. Esses, por sua vez, ao não receber uma receita, acabam se sentindo desorientados em seus primeiros anos de atuação (LIPPE; BASTOS, 2008).

Pensando nesses e em outros problemas relacionados à formação dos professores universitários, Cachapuz (2002) defende que é de extrema importância que hajam mais discussões a respeito da valoração do ensino universitário, levando as Universidades a repensar seu papel e suas responsabilidades. Suas colocações são baseadas em uma discussão realizada na Conferência Mundial da UNESCO em 1998, que visou a transformação do ensino universitário em um centro de formações permanente, obrigando 
uma reestruturação de suas estratégias didáticas, visando uma melhoria global da qualidade de ensino.

Segundo Cachapuz (2002), todos os professores trazem consigo alguns referenciais com base em seu repertório de representações mentais, mais ou menos claro, mais ou menos consciente do modo como deve agir um professor universitário. Tais funções incluem: conseguir financiamento para projetos de pesquisa, ter uma equipe formada, publicar artigos periodicamente, realizar conferências em congressos de grande prestígio em sua área [...], sob o ponto de vista do ensino deve-se ter orientandos de nível de mestrado e doutorado e não ter problema nenhum com os alunos. Porém, é indiscutível que as competências didáticas de um professor universitário, em relação ao ensino, vão muito além das citadas acima. Cachapuz (2002) afirma ainda que tal relato parece descrever mais um robô do que um ser humano, para ele as Universidades necessitam reinventar os laços entre pesquisa e ensino. Sendo assim, necessita-se de uma formação específica para esses docentes do ensino superior, que, muitas vezes, nunca tiveram a oportunidade de discutir aspectos educacionais.

Januario (2007) afirma que, mesmo com um grande conhecimento em sua área de teoria específica, se encontram em um desamparo e desconhecimento sobre o processo de ensino-aprendizagem, o que dificulta o desenvolvimento das habilidades essenciais para a prática docente.

Às colocações aqui apresentadas, podemos aliar aquelas relacionadas ao uso das imagens por parte de docentes que atuam na formação inicial de professores de Ciências. A presente pesquisa pretende contribuir justamente para ampliar o conhecimento sobre tal temática. 


\title{
4. Metodologia
}

\author{
"O processo criado da ciência se inicia com o \\ reconhecimento de problemas e culmina com a \\ construção de teorias que, por sua vez, \\ originam novos problemas [...]" (COLOM, \\ 2004, pg.19).
}

\subsection{Natureza da Pesquisa}

Esta pesquisa é de natureza predominantemente qualitativa, porém alguns dados são passiveis de quantificação.

Segundo Minayo (2006) a pesquisa qualitativa:

\begin{abstract}
"caracteriza-se pela empiria e pela sistematização progressiva de conhecimento até a compreensão lógica interna do grupo ou do processo em estudo. Por isso, é também utilizada para a elaboração de novas hipóteses, construção de indicadores qualitativos, variáveis e tipologias" (pg.57).
\end{abstract}

Para Weber (apud ANDRÉ, 2008), a pesquisa qualitativa se diferencia da quantitativa porque o seu foco de investigação é a compreensão dos significados atribuídos pelos sujeitos e suas ações, para isso torna-se necessário situar a pesquisa em um contexto bem definido.

A pesquisa qualitativa tem uma estrutura diferenciada por levar em conta os fatores apontados por Minayo (2006):

\begin{abstract}
"(a) investir em instrumentos que permitam compreensão de diferenciações internas e de homogeneidades; (b) assegurar que a escolha do lócus e do grupo de observação e informação contenham o conjunto das experiências e expressões que se pretende objetivar na pesquisa; (c) privilegiar os sujeitos sociais que detêm os atributos que o investigador pretende conhecer; (d) definir claramente o grupo social mais relevante, ou seja, sobre o qual recai a pergunta central da pesquisa. Centralizar nele o foco das entrevistas, dos grupos focais e da observação; (e) dar atenção a todos os outros grupos que interagem com o foco principal, buscando compreender o papel de cada um em suas interações; (f) trabalhar num processo de inclusão progressiva das descobertas do campo, confrontando-as com as teorias que demarcam o objeto; (g) nunca desprezar informações ímpares e não repetidas, cujo potencial explicativo acaba por ser importantes na descoberta da lógica interna do grupo; (h) considerar um número suficiente de interlocutores para permitir reincidência e complementaridade das informações; (i) certificar-se de que o quadro empírico da pesquisa esteja mapeado e compreendido; (j) sempre que possível, prever uma triangulação de
\end{abstract}


técnicas e até de métodos, isto é, em lugar de se restringir a apenas uma fonte de dados, multiplicar as tentativas de aproximação”. (MINAYO, 2006, pg. 197).

Esta pesquisa é considerada como um estudo de caso, pois seu foco é entender uma situação pontual (duas disciplinas do curso de Licenciatura em Ciências da Natureza USP). Assim, não é possível realizar uma generalização dos resultados. Um estudo de caso trata-se de um tipo de investigação sistemática, que tem como principal objetivo entender como se dá o funcionamento de um pequeno grupo de indivíduos, focando-se mais na descrição e compreensão do processo de construção de significados pelo grupo do que com os resultados em si (ANDRÉ, 2008).

Segundo Kenny e Grotelues (1980, apud ANDRÉ, 2008), nesse tipo de investigação não é relevante até que ponto as informações dadas pelos participantes são verdadeiras. Os autores destacam que o grupo deve ser escolhido por sua singularidade, podendo ser ou não representativo de outros grupos. De modo que, não podemos afirmar no fim dessa pesquisa que todos os docentes de disciplinas de biodiversidade utilizam imagens da mesma maneira que os analisados na presente pesquisa.

O estudo de caso é bastante descritivo, dando ao leitor elementos para conhecer o contexto da pesquisa e com base nessas informações chegar às mesmas ou outras conclusões do pesquisador e também reconhecer se é possível transferir os resultados para outro contexto (ANDRÉ, 2008).

\footnotetext{
"Os estudos de caso também são valorizados pela sua capacidade heurística, isto é, por oferecer insights e conhecimentos que clarifiquem ao leitor os vários sentidos do fenômeno estudado, levando-o a descobrir novas significações, a estabelecer novas relações, ampliando suas experiências. Estes insights podem a vir a se tornar hipóteses que sirvam para estruturar futuras pesquisas, o que torna o estudo de caso especialmente relevante na construção de novas teorias e no avanço do conhecimento da área" (ANDRÉ, 2008, p. 53).
}

Lüdke e André (1996) definem os seguintes princípios para a estruturação de um estudo de caso qualitativo:

- Visar à descoberta, criando um o quadro teórico inicial que servirá de base para a construção de novas interpretações e inclusão de novos elementos de análise;

- Enfatizar o contexto para ter uma apreensão mais completa de um objeto do estudo, relacionando um conjunto de critérios próprio do local onde o objeto se situa;

- Retratar a realidade de forma completa e profunda; 
- Usar uma variedade de fontes de informação: o pesquisador recorre a dados coletados em diferentes momentos, em situações variadas e com diversos tipos de informantes, daí a importância da utilização de questionários e de entrevistas;

- Há uma necessidade de em vez de se pensar se o caso estudo é um bom representativo da realidade, explorar mais a questão "o que posso (ou não) aplicar deste caso na minha situação?”;

- Representar os diferentes pontos de vistas presentes numa situação social;

- Os relatos devem utilizar uma linguagem mais acessível do que os outros relatórios de pesquisa.

Segundo tais princípios, podemos caracterizar a presente pesquisa como um estudo de caso. 


\subsection{Sujeitos do Estudo e seu Contexto de Atuação}

Como já foi mencionado anteriormente, este estudo enfoca as imagens escolhidas por alguns docentes para suas aulas de um curso de Licenciatura em Ciências da Natureza de uma universidade pública do Estado de São Paulo. O objetivo de tal curso é formar profissionais com preparo pedagógico adequado e uma visão abrangente das Ciências da Natureza (Ciências do Universo, da Terra, da Vida, Física e Química) e das relações entre os processos biológicos e os conceitos físicos e químicos presentes na natureza, estudando o ser vivo como um todo inserido na natureza.

Como não seria possível analisar todas as disciplinas do curso, fizemos um recorte enfocando a biodiversidade, pois, com base em nossa experiência, acreditamos ser uma das áreas com intensa utilização de imagens. Como citado anteriormente, duas disciplinas são o objeto direto da presente pesquisa, uma que aborda a diversidade zoológica e outra que aborda a diversidade botânica. A primeira disciplina é ministrada por dois professores (que chamaremos de A e B) e a segunda por um professor somente.

Dessa forma, temos três docentes como sujeitos da presente pesquisa e três conjuntos de material didático serão analisados (um referente a cada professor). A seguir, apresentamos informações sobre tais docentes visando fornecer maior contexto sobre a atuação dos mesmos. A fonte de tais informações foi o currículo Lattes desses docentes.

O professor A da disciplina da Diversidade Zoológica possui graduação em Biociências pela Universidade de São Paulo (USP) (1997), mestrado (2001) e doutorado (2005) em Ciências Biológicas (Zoologia), ambos pela USP. É docente do curso desde 2007, onde ministra disciplinas relacionadas à Biologia, com ênfase em Zoologia. Sua pesquisa e publicações estão voltadas para sistemática de Opiliones (Arachnida) e evolução de caracteres químicos e comportamentais de defesa nesse grupo. Atualmente, está dedicado a: (1) sistemática e taxonomia de Pachylinae (Gonyleptidae) e grupos próximos de Gonyleptidae; (2) evolução de caracteres comportamentais e químicos de defesa aplicados à filogenia de Opiliones e (3) desenvolvimento da coleção didática zoológica (Fonte: Currículo Lattes).

O professor B da disciplina da Diversidade Zoológica possui graduação em Ciências Biológicas (2000) e doutorado em Zoologia pela USP (2005). Durante o doutorado, realizou estágios na França (Université de Bourgogne) e na Argentina (Universidad Nacional de Córdoba). De 2006 a 2007, realizou um pós-doutorado na University of Nebraska e, durante esse período, realizou estágio na Harvard University. 
Iniciou um pós-doutorado no Instituto de Biociências da USP em 2008. Tem experiência na área de Zoologia, com ênfase em comportamento animal e morfologia de grupos recentes, atuando principalmente nos seguintes temas: ecologia sensorial, comunicação química e comportamento de aracnídeos (Arachnida).

O professor da disciplina de Diversidade Botânica possui graduação em Ciências Biológicas pela USP (1982), mestrado em Botânica (1989) e doutorado em Ciências Biológicas (1996), também cursados na USP. É docente da universidade desde 1996 e atua no curso desde 2005 como professor em áreas correlatas à Biologia, ênfase Botânica. Suas pesquisaa e publicações estão centradas em sistemática de Campanulaceae, florística, fitossociologia e química de cera foliar de plantas em áreas naturais, como o Cerrado e a Mata Atlântica, e também em áreas urbanas. Atualmente, está dedicada a: (1) estudo das espécies brasileiras de Siphocampylus, com ênfase em dados morfológicos, químicos e moleculares; (2) levantamento de ervas ruderais em áreas urbanas na cidade de São Paulo; (3) a vegetação da cidade de São Paulo após 100 anos da obra de Usteri; (4) o potencial para o ensino de Botânica nas escolas do Distrito de São Miguel Paulista; (5) estabelecimento e incremento da coleção didático-científica, Herbário Físico e Virtual.(Fonte: Currículo Lattes).

A seguir, visando complementar a contextualização da atuação dos nossos sujeitos de pesquisa, apresentamos mais detalhes das disciplinas que são foco para a classificação de imagens realizadas no presente trabalho.

\section{Disciplina Diversidade Zoológica}

O objetivo da disciplina é ensinar os alunos sobre a diversidade dos animais, sua morfologia funcional e adaptação aos diferentes ambientes. Seu programa aborda: origem evolutiva dos animais; esponjas; cnidários; o surgimento da simetria bilateral: platelmintes, nematelmintes; moluscos; animais segmentados: anelídeos e artrópodes; equinodermes; origem evolutiva dos cordados; peixes; a conquista do ambiente terrestre: anfíbios; répteis; aves; mamíferos; filogenias. Células; tecidos; órgãos; sistemas digestivos; sistemas respiratórios, sistemas circulatórios; sistemas imunológicos; sistemas nervosos; sistemas sensoriais; sistemas excretores; sistemas locomotores; controle do meio interno; sistemas reprodutores; aspectos do desenvolvimento. 
A disciplina é ministrada no $5^{\circ}$ semestre do curso e possui 4 créditos, o que equivale a $4 \mathrm{~h}$ semanais de aula. As aulas são organizadas da seguinte forma: as primeiras $2 \mathrm{~h}$ são teóricas e as outras $2 \mathrm{~h}$ são aulas práticas no laboratório de zoologia.

As aulas ministradas são divididas entre os professores A e B seguindo o cronograma da Tabela 4.

Tabela 4 - Cronograma da disciplina de Diversidade Zoológica

\begin{tabular}{|c|c|c|c|}
\hline Aula & Teórica & Prática & Prof. \\
\hline 1 & Sistemática filogenética & Exercício de sistemática filogenética & A \\
\hline 2 & Protozoários e introdução a Metazoa & Filme sobre Protozoários. & A \\
\hline 3 & Porifera e Cnidaria & Hidra & A \\
\hline 4 & $\begin{array}{l}\text { Bilateria e Lophotrocozoa; } \\
\text { Platyhelminthes }\end{array}$ & Planária & A \\
\hline 5 & Mollusca & Lula & A \\
\hline 6 & Annelida & Minhoca & $\mathrm{B}$ \\
\hline 7 & Prova 1/ Ecdysozoa e Nematoda & Lombriga & A \\
\hline 8 & Arthropoda 1 & Aracnídeos & A \\
\hline 9 & Arthropoda 2 & $\begin{array}{l}\text { Aracnídeos, crustáceos, miriápodes e } \\
\text { insetos }\end{array}$ & A \\
\hline 10 & Deuterostomia e Echinodermata & Estrela, ouriço, ofiúro e lírio do mar & B \\
\hline 11 & Vertebrata. Agnatha, Chondrichthyes & 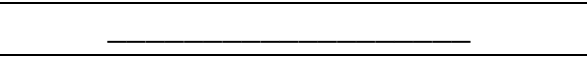 & B \\
\hline 12 & Osteichthyes e Amphibia & & B \\
\hline 13 & Reptilia e Aves & Anfioxo e Rã & $\mathrm{B}$ \\
\hline 14 & Mammalia & Serpentes & $\mathrm{B}$ \\
\hline 15 & \multicolumn{3}{|c|}{ Visita ao Museu de Anatomia da Veterinária da USP } \\
\hline 16 & \multicolumn{3}{|c|}{ Prova 2.} \\
\hline
\end{tabular}

\section{Disciplina Diversidade Botânica}

O objetivo da disciplina é capacitar o aluno a identificar os dois grandes grupos do reino Plantae: atraqueófitas e traqueófitas, assim como o reino Fungi. Além de possuir uma abordagem evolutiva, a disciplina pretende apresentar as estruturas e funções dos grupos citados e enfatizar a importância ecológica e econômica de tais grupos. Seu programa aborda: origem e evolução do reino Plantae; aquisições que capacitaram o grupo para a conquista do meio terrestre; relações evolutivas entre os filos de Plantae ("Briófitas", "Pteridófitas", "Gymnospermas" e Angiospermas), compreendidas a partir da morfologia, do metabolismo, da reprodução, da biologia molecular e da ocupação do planeta; fungos (quitrídeos, zigomicetos, ascomicetos e basidiomicetos): razões para constituírem um reino à parte; caracteres estruturais, fisiológicos e moleculares que apoiam tal circunscrição; para 
ambos os reinos: rotas metabólicas; formas de obtenção de alimento; aspectos reprodutivos (inclui ciclos de vida); importância ecológica e econômica de cada reino.

Esta disciplina é oferecida no $5^{\circ}$ semestre do curso e conta 4 créditos/aula, o que equivale a $4 \mathrm{~h}$ semanais de aula. As aulas práticas são ministradas no laboratório de botânica em semanas alternadas. Cada semestre possui em média 8 aulas teóricas

A dinâmica das aulas é a seguinte: o professor explica o conteúdo teórico, faz um resumo na lousa e depois mostra as imagens, sendo que não há um arquivo de imagens para cada aula. Assim cada arquivo pode ser utilizado em duas ou mais aulas. Para a presente investigação, organizamos tais arquivos por seus temas, conforme apresentado na Tabela 5.

Tabela 5 - Tema das Aulas de Diversidade Botânica.

\begin{tabular}{|c|c|}
\hline Arquivo & Parte Específica \\
\hline $1-$ Estruturas & 1 - Raízes \\
\hline $1-$ Estruturas & $2-$ Folhas \\
\hline $1-$ Estruturas & 3 - Modificações \\
\hline 2 - Plantas Avasculares & 1 - Exemplos \\
\hline 3 - Plantas Vasculares sem semente & 1 - Novidades Evolutivas \\
\hline 3 - Plantas Vasculares sem semente & 2 - Reprodução e ciclo de vida \\
\hline 3 - Plantas Vasculares sem semente & 3 - Novidades Evolutivas \\
\hline 3 - Plantas Vasculares sem semente & 4 - Reprodução e ciclo de vida \\
\hline 4 - Plantas Vasculares sem/com semente & 1 - Exemplos \\
\hline 4 - Plantas Vasculares com semente & 2 - Reprodução e Flores \\
\hline 4 - Plantas Vasculares com semente & $3-$ Frutas \\
\hline $5-$ Fungos & $1-$ Fungos \\
\hline
\end{tabular}




\subsection{Critérios utilizados para Análise das Imagens}

Primeiramente, é necessário termos bem definido o que consideramos uma “imagem”. Para tanto, nos baseamos em Moles (1981), que oferece uma definição abrangente, considerando uma imagem como toda mensagem visual com algum grau de iconicidade (grau de realismo), portanto, variando desde o objeto em si até sua descrição por meio de palavras. Como mencionado anteriormente, escolhemos trabalhar com os níveis de iconicidade de 4 a 9, criados por Moles (1981) e apresentados na Tabela 1 (ver item 3.2.1 da presente dissertação). A seguir destacaremos novamente apenas tais níveis, que são os utilizados no presente trabalho:

\begin{tabular}{|c|c|c|c|}
\hline Níveis & Definição & Critérios & Exemplos \\
\hline 9 & $\begin{array}{l}\text { A fotografia ou projeção } \\
\text { realista sobre um plano. }\end{array}$ & $\begin{array}{c}\text { Projeção perspectiva rigorosa, semitons } \\
\text { e sombras }\end{array}$ & Catálogos ilustrados e afiches. \\
\hline 8 & $\begin{array}{l}\text { Desenho ou fotografia } \\
\text { ditos "sem contornos" }\end{array}$ & $\begin{array}{l}\text { Critérios de continuidade e de } \\
\text { fechamento de forma }\end{array}$ & $\begin{array}{l}\text { Afiches, catálogos, prospectos e } \\
\text { fotografias técnicas. }\end{array}$ \\
\hline 7 & $\begin{array}{l}\text { Esquemas anatômicos ou } \\
\text { de construção. }\end{array}$ & $\begin{array}{c}\text { Abertura da Carter ou de envelope. } \\
\text { Respeito a tomografia. Arbitrário de } \\
\text { valores. Quantificação de elementos ou } \\
\text { simplificação. }\end{array}$ & $\begin{array}{l}\text { Corte anatômico de um motor a } \\
\text { explosão. Planejamento de cabos } \\
\text { para um receptor de rádio. Carta } \\
\text { geográfica. }\end{array}$ \\
\hline 6 & $\begin{array}{l}\text { Vista "estourada" } \\
\text { (éclatée). }\end{array}$ & $\begin{array}{c}\text { Disposição perspectiva de peças } \\
\text { conforme suas relações de vizinhança } \\
\text { topológica }\end{array}$ & $\begin{array}{l}\text { Objetos técnicos de manuais de } \\
\text { instrução. }\end{array}$ \\
\hline 5 & $\begin{array}{l}\text { Esquema de princípio; } \\
\text { eletricidade e eletrônica }\end{array}$ & $\begin{array}{c}\text { Substituição dos elementos por } \\
\text { símbolos normalizados. Passagens de } \\
\text { topografia à topologia "Geometrização" }\end{array}$ & $\begin{array}{l}\text { Plano esquematizado do metrô. } \\
\text { Plano dos cabos de um receptor de } \\
\text { TV ou uma parte do radar. }\end{array}$ \\
\hline 4 & $\begin{array}{l}\text { Organograma ou Block } \\
\text { esquema. }\end{array}$ & $\begin{array}{l}\text { Os elementos são caixas pretas } \\
\text { funcionais ligadas por conexões } \\
\text { lógicas: análise das funções lógicas. }\end{array}$ & $\begin{array}{l}\text { Organograma de um } \\
\text { empreendimento. "Flowchart" de } \\
\text { um programa de computador. Série } \\
\text { de operações químicas. }\end{array}$ \\
\hline
\end{tabular}

A análise foi feita com base nos materiais didáticos criados pelos professores para servir como apoio para suas aulas. Tais materiais foram apresentados durante as aulas dos referidos professores por meio de projetor digital. Os professores forneceram os materiais em formato PowerPoint ou PDF. Assim, imagens disponíveis na aula de outras fontes não serão analisadas, como imagens em livros ou desenhos feitos na lousa. Todos os arquivos fornecidos pelos professores foram convertidos ao formato PDF e estão anexados à presente dissertação na forma de um CD, visando possibilitar ao leitor fazer sua própria análise das imagens, comparando-a com a análise por nós desenvolvida.

Outra observação necessária é que algumas imagens se repetem durante uma aula, sendo contadas toda vez que aparecem, uma vez que em outro slide ela pode mudar de categoria conforme o texto e as demais imagens que a acompanham, formando outro 
contexto para a imagem. Imagens que compõem animações presentes em um slide (ex. um esquema básico que é completado aos poucos durante a fala do professor) são analisadas como várias imagens, pois a cada slide é considerado uma nova imagem.

Algumas imagens utilizadas nas aulas, que chamaremos de "compostas", são montagens feitas pelo professor utilizando, na verdade, várias imagens. Tais imagens serão consideradas como sendo uma unidade, pois é o conjunto da imagem "composta" que apresenta uma função e não as imagens isoladas que a compõem. Um exemplo seria a seguinte imagem do tipo esquemática, que se configura pela junção de várias imagens do tipo "fotografia" (Figura 2). Ressaltamos que imagens que apenas estão apresentadas no mesmo slide mas não possuem relação direta entre si (por exemplo, não são ligadas por seta, não apresentam uma margem ou uma legenda em comum) foram analisadas separadamente.

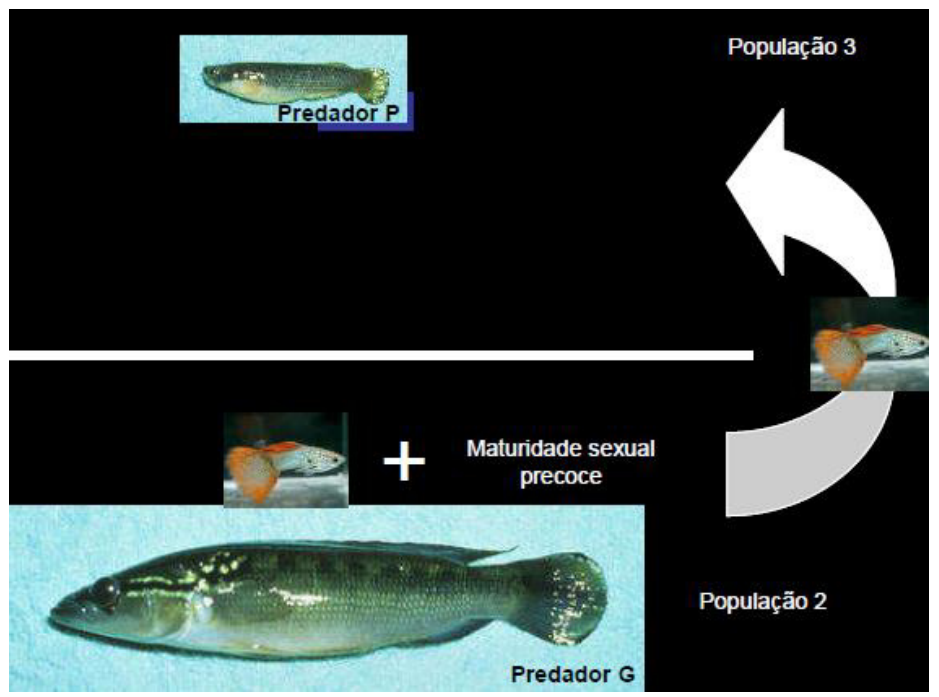

Figura 2 - Exemplo de Imagem Composta. 


\subsubsection{Análise Morfológica}

Realizamos uma contagem geral das imagens presentes em cada conjunto de material didático (lembrando que cada conjunto corresponde a um professor, dois da disciplina Diversidade Zoológica e um da disciplina Diversidade Botânica). As imagens foram classificadas segundo:

- tipo: fotografia, desenho ou esquema ${ }^{1}$;

- coloração: preto e branco ou colorido;

- tamanho: pequeno, médio, grande ou muito grande;

- escala: presente ou ausente.

Essa metodologia é semelhante à utilizada por Sebata et. al. (2005) ao analisarem imagens em livros didáticos de Química. Porém, em sua pesquisa, o objeto de estudo (livros) permitia uma análise das imagens relacionadas com o texto escrito, o que não foi objeto da presente investigação.

A análise morfológica nos permite perceber alguns indícios sobre as concepções que os docentes sujeitos da presente pesquisa têm sobre qual o melhor tipo de imagem a se utilizar. Por exemplo, se um professor prefere utilizar somente imagens coloridas e do tipo fotografia, podemos inferir que ele prefere utilizar aquelas com conteúdo mais parecido com o ao real.

Quanto à questão das escalas, temos que na área científica elas são de extrema importância, não só para a representação, mas também na identificação de espécies. Assim, consideramos como escala não apenas a escala formalizada, mas algo presente na imagem que seja de tamanho médio conhecido para se tomar como referência para o tamanho dos objetos representados na imagem, como por exemplo, um lápis, um dedo humano, uma régua, etc.

Para a análise de tamanho de imagens, definimos que imagens:

- pequenas ocupam menos de $25 \%$ do espaço total do slide;

${ }^{1}$ Definição segundo Aumont (1993) na qual esquema é um tipo de imagem cuja forma é econômica, ou seja, deve ser mais simples, mais enfática naquilo que quer destacar, como por exemplo, gráficos, fluxogramas, mapas conceituais etc.. 
- médias ocupam $25 \%$;

- grandes entre $25 \%$ a $50 \%$;

- muito grandes mais de $50 \%$.

\subsubsection{Análise Funcional}

Para a análise funcional, criamos uma classificação baseada nas classificações de Duchastel e Waller, (1979) e de Kress e Van Leeuwen (2006), voltada para o uso de imagens em aulas de cunho científico. Uma mesma imagem pode apresentar mais de uma função.

A nova classificação funcional utilizou, além dos referenciais teóricos já citados, alguns resultados da pesquisa de Navarro e Ursi (2011), na qual um questionário aberto sobre utilização de imagens foi respondido por 15 docentes do curso de Licenciatura em Ciências da Natureza, gerando alguns subsídios interessantes. Por exemplo, uma das questões era: “Com que finalidade você utiliza imagens em suas aulas?”. Essa pergunta nos deu alguns indícios sobre quais as funções das imagens mais trabalhadas. Uma das funções que mais foram evidenciadas pelos docentes no questionário foi a de "ilustrar as aulas".

Além desse questionário, também realizamos observações e anotações sistemáticas sobre o uso das imagens em pelo menos três aulas de cada um dos três docentes que são sujeitos da presente pesquisa.

A Tabela 3 apresenta a classificação, com nove categorias, que desenvolvemos para a análise das imagens nesta pesquisa.

Tabela 3 - Classificação funcional de imagens utilizada na presente pesquisa. Classificação modificada a partir dos trabalhos de Duchastel e Waller, (1979) e de Kress e Van Leeuwen (2006) e incorporou dados obtidos por Navarro e Ursi (2012).

\begin{tabular}{|l|l|}
\hline Decorativas & $\begin{array}{l}\text { São imagens utilizadas para não deixar espaços em branco no slide ou } \\
\text { página, não tendo nenhuma relação com o texto ou tema da aula, sendo } \\
\text { desnecessárias ao entendimento do conceito (Figura 3). }\end{array}$ \\
\hline Ilustrativa & $\begin{array}{l}\text { São imagens que têm apenas a função de ilustrar a aula, estando ligada } \\
\text { ao conteúdo ou ao tema da aula, ajudando a visualização de um objeto, } \\
\text { ser vivo e/ou uma paisagem. Uma imagem estática que não induz a } \\
\text { uma leitura direcional, não tem relação com outra imagem e não } \\
\text { apresenta uma parte em destaque (Figura 4). }\end{array}$ \\
\hline
\end{tabular}


Tabela 3 - Continuação

\begin{tabular}{|c|c|}
\hline Retentora & $\begin{array}{l}\text { São imagens que ajudam na memorização de uma informação, por } \\
\text { exemplo, imagens em forma de exercício de memorização do tipo } \\
\text { complete (Figura 5), imagens que relacionam algo conhecido com algo } \\
\text { desconhecido (Figura 6), imagens para divertir a aula, etc. }\end{array}$ \\
\hline Comparativa & $\begin{array}{l}\text { São imagens que visam realizar uma comparação entre imagens } \\
\text { semelhantes, estando uma ao lado da outra no slide ou folha. Ex. Seres } \\
\text { da mesma família (Figura 7), diferenças entre indivíduos de um grupo, } \\
\text { mudanças evolutivas ao longo do tempo, etc. }\end{array}$ \\
\hline Impactante & $\begin{array}{l}\text { São imagens que tentam impactar o observador, mostrando algo que } \\
\text { foge de sua realidade, algo incomum, ou surpreendente, por exemplo, } \\
\text { uma ferida de guerra, um espécie de tamanho ou cor diferente (Figura } \\
8,9 \text { e 10), um ser vivo alterado em laboratórios, etc. }\end{array}$ \\
\hline Constitutiva & $\begin{array}{l}\text { São imagens que destacam as partes de um todo, mostrando a } \\
\text { constituição de objetos, seres vivos ou processo, tendo ao menos três } \\
\text { segmentos, identificados com os nomes de cada parte, normalmente } \\
\text { com setas (Figura 11). }\end{array}$ \\
\hline Organizativa & $\begin{array}{l}\text { São imagens que tentam organizar informações visuais ou uma } \\
\text { classificação, por exemplo, uma pirâmide alimentar, organização do } \\
\text { tempo geológico (Figura 12), etc. }\end{array}$ \\
\hline Processual & $\begin{array}{l}\text { São imagens que tem um sentido direcional de leitura, com um } \\
\text { começo, meio e fim, normalmente ligados por setas, mostrando } \\
\text { processos, tais como: desenvolvimentos, movimentos, evoluções, etc. } \\
\text { Ex. ciclos de vida, árvores genealógicas, mapas de conceitos, etc } \\
\text { (Figura 13). }\end{array}$ \\
\hline Numéricas & $\begin{array}{l}\text { São imagens que auxiliam na análise de dados numéricos como } \\
\text { gráficos de linha, pizza, de curva, entre outros tipos de gráficos. }\end{array}$ \\
\hline
\end{tabular}

A análise funcional indica qual a função de cada imagem. Na presente investigação, inferimos essa função basicamente pelo material em arquivos fornecidos pelos professores, mas assumimos como pressuposto que tal função depende fortemente da atuação do professor. Embora nossa análise seja com base apenas no material, outra análise com observação de cada aula poderia gerar resultados diferentes, como por exemplo, a imagem do gênio da lâmpada (Figura 3). 
Ela é um exemplo de uma imagem classificada nesta pesquisa como Decorativa. Porém, ao observarmos uma aula em que o professor a utilizou, percebemos que ele o fez para chamar a atenção dos alunos para a ideia de que os cientistas não são gênios como se acredita e, posteriormente, comparar ao caso de Darwin, que, segundo as falas do professor, não era um gênio, tinha "desempenho ruim" na época de escola, mas com muito esforço, pesquisa e estudo elaborou a Teoria da Evolução. Assim, assumimos a priori essa limitação de nossa análise funcional, mas acreditamos que ela seja útil dentro dos objetivos traçados para o presente trabalho.

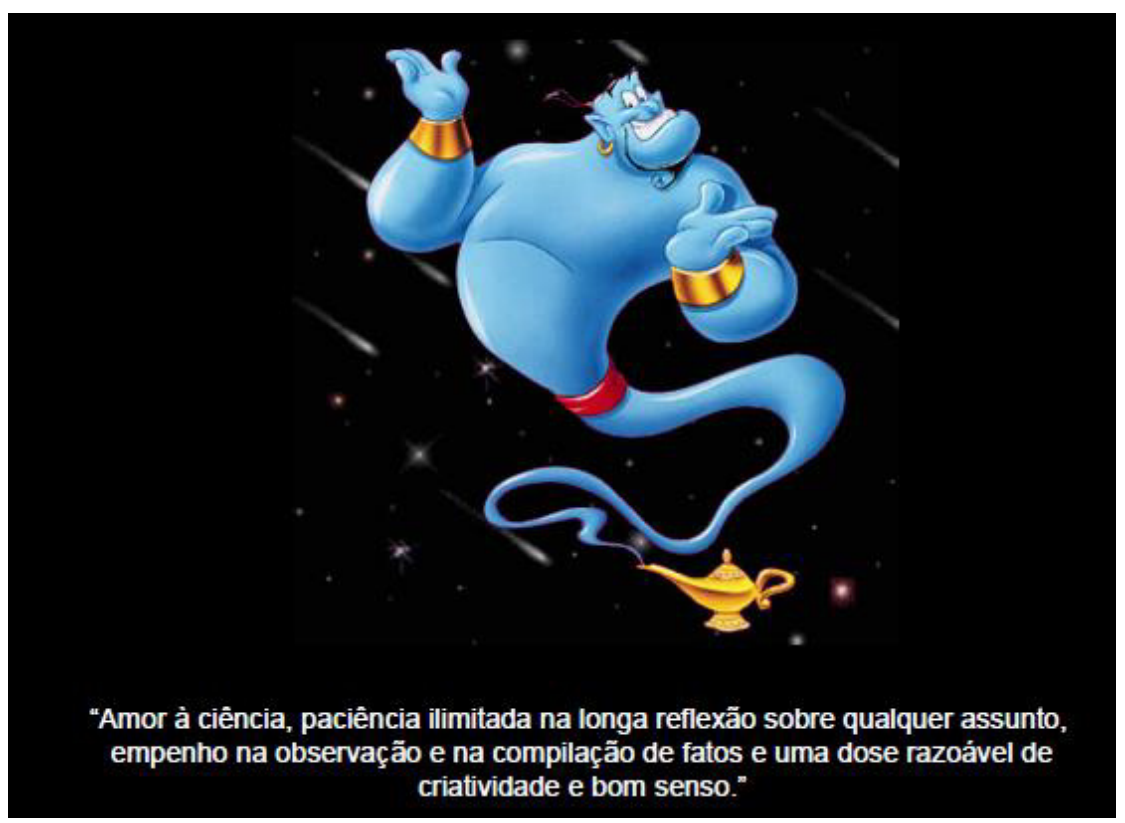

Figura 3- Exemplo de Imagem Decorativa.

Apresentamos a seguir algumas exemplificações complementares visando deixar as novas categorias criadas para o presente trabalho mais claras.

$\mathrm{Na}$ categoria Ilustrativa, incluímos as imagens que mostram o ser ou objeto como ele é, sem nenhum outra função específica além de ilustrar a fala ou explicação do professor (Figura 4). 


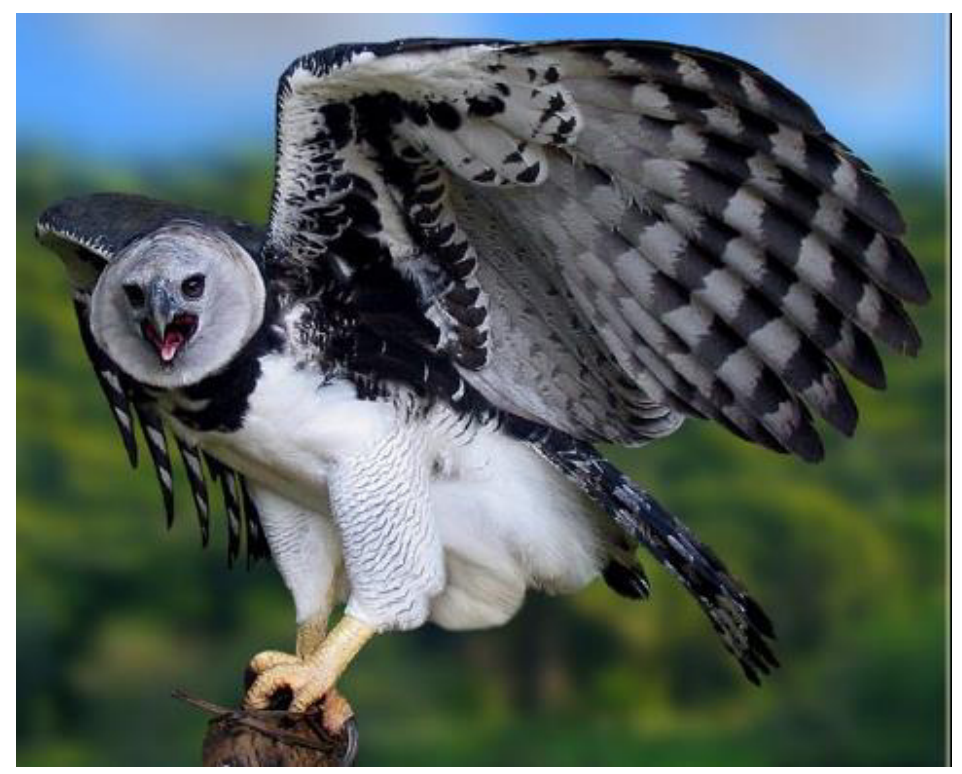

Figura 4 - Exemplo de Imagem Ilustrativa.

$\mathrm{Na}$ categoria Retentora, que enquadra as imagens que auxiliam o aluno a memorizar o conteúdo, pode-se, por exemplo, incluir uma imagem do personagem de desenho animado como Bob Esponja (Figura 5). Por ser um personagem bastante conhecido e pertencer ao reino dos poríferos, pode ajudar a reter informações sobre quais espécies pertencem a esse grupo taxonômico. Outro exemplo, seria uma imagem interativa feita pelo professor para ajudar os alunos a lembrarem os conteúdos estudados na aula, como os nomes de alguns táxons abordados na aula para serem completados (Figura 6).

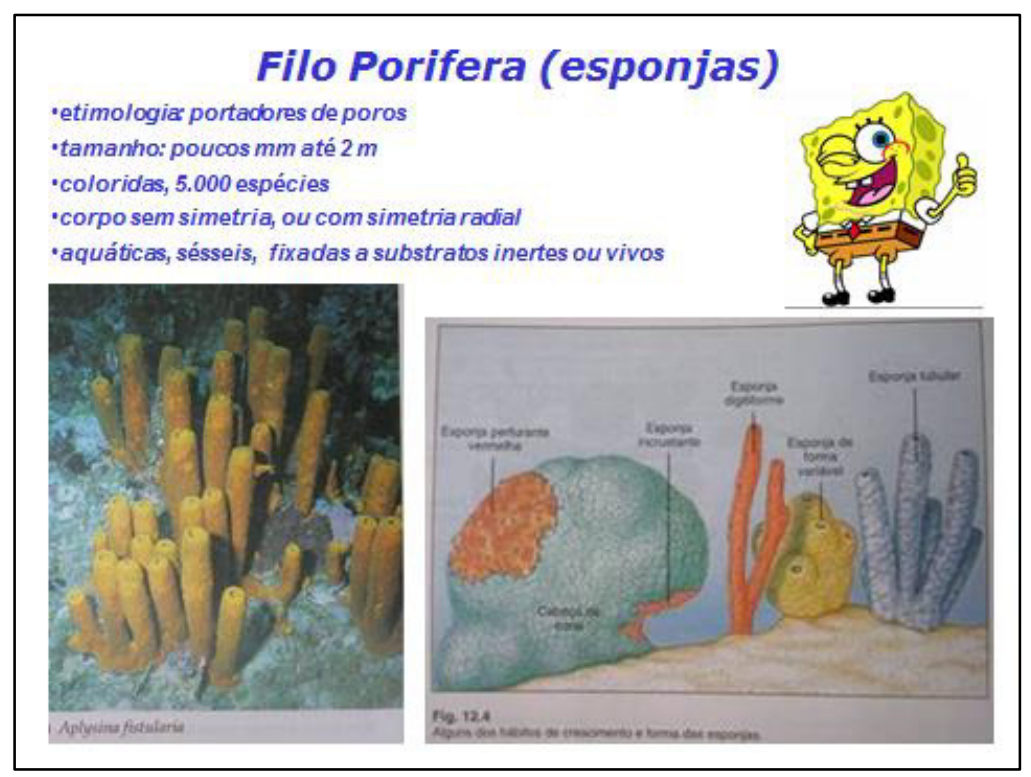

Figura 5- Exemplo de Imagem Retentora. 


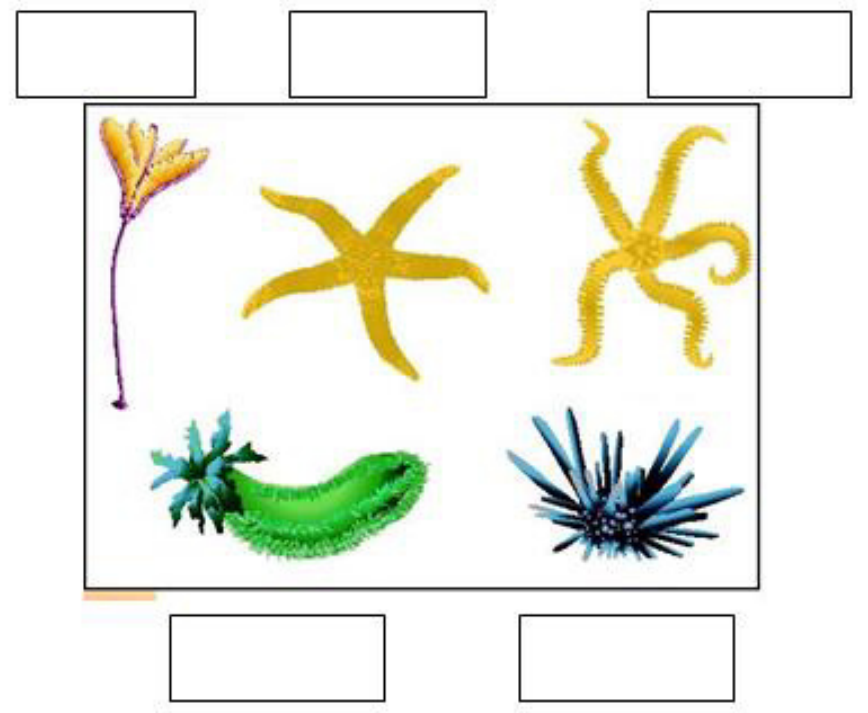

Figura 6 - Exemplo de Imagem Retentora.

As imagens da categoria Comparativa podem apresentar várias espécies da mesma família, como a imagem das tartarugas (Figura 7), ou comparar diferença de colorações de sapos (Figura 8).

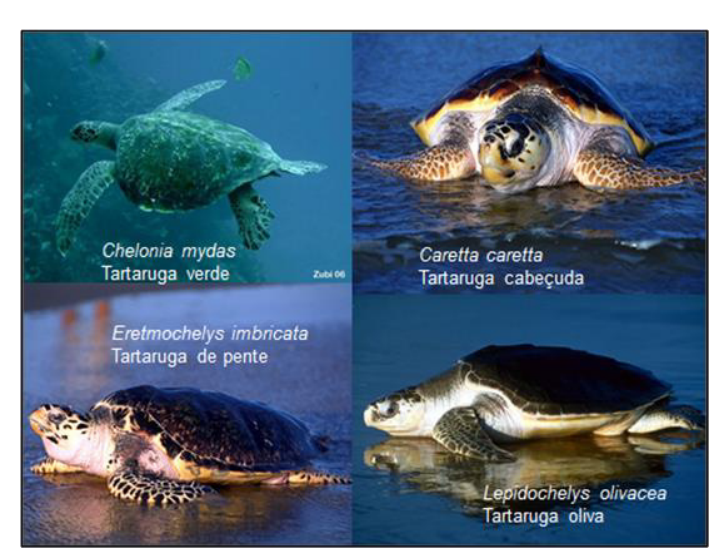

Figura 7 - Exemplo de Imagem Comparativa

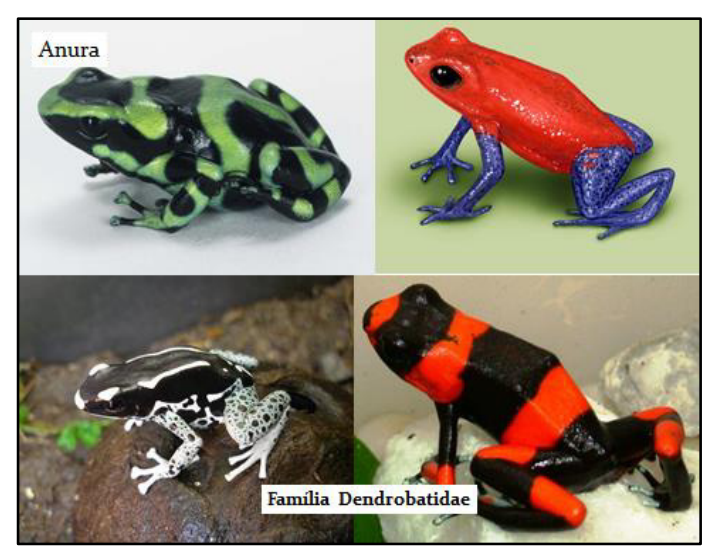

Figura 8 - Exemplo de Imagem Comparativa e Impactante

As imagens Impactantes são aquelas que provocam um impacto no observador. Foram consideradas imagens de paisagens raras, espécies raras ou com cores exóticas, entre outras (Figuras 8-9-10). A Figura 8 também pode ser considerada Impactante, pois apresenta animais de coloração muito diferente. Ela é, portanto, o que denominamos de imagem com múltiplas funções. 


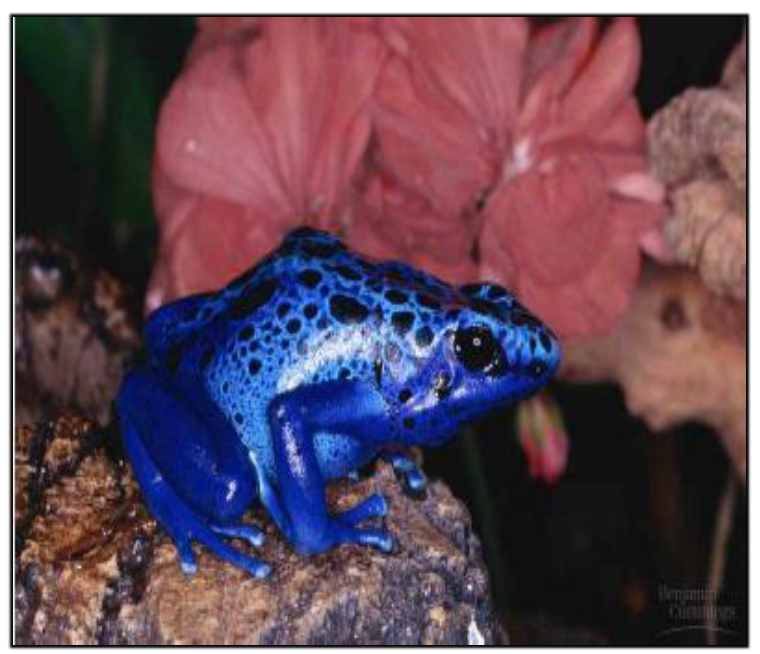

Figura 2 - Exemplo de Imagem Impactante.

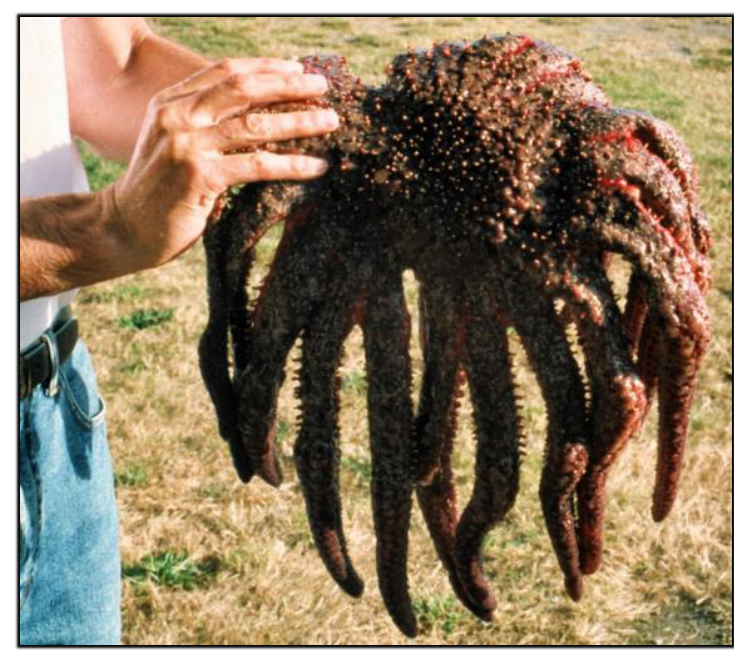

Figura 1 - Exemplo de Imagem Impactante 2.

As imagens Constitutivas são aquelas que mostram as partes de um todo, como no exemplo abaixo, mostrando em destaque as partes internas do anelídeo (Figura 11).

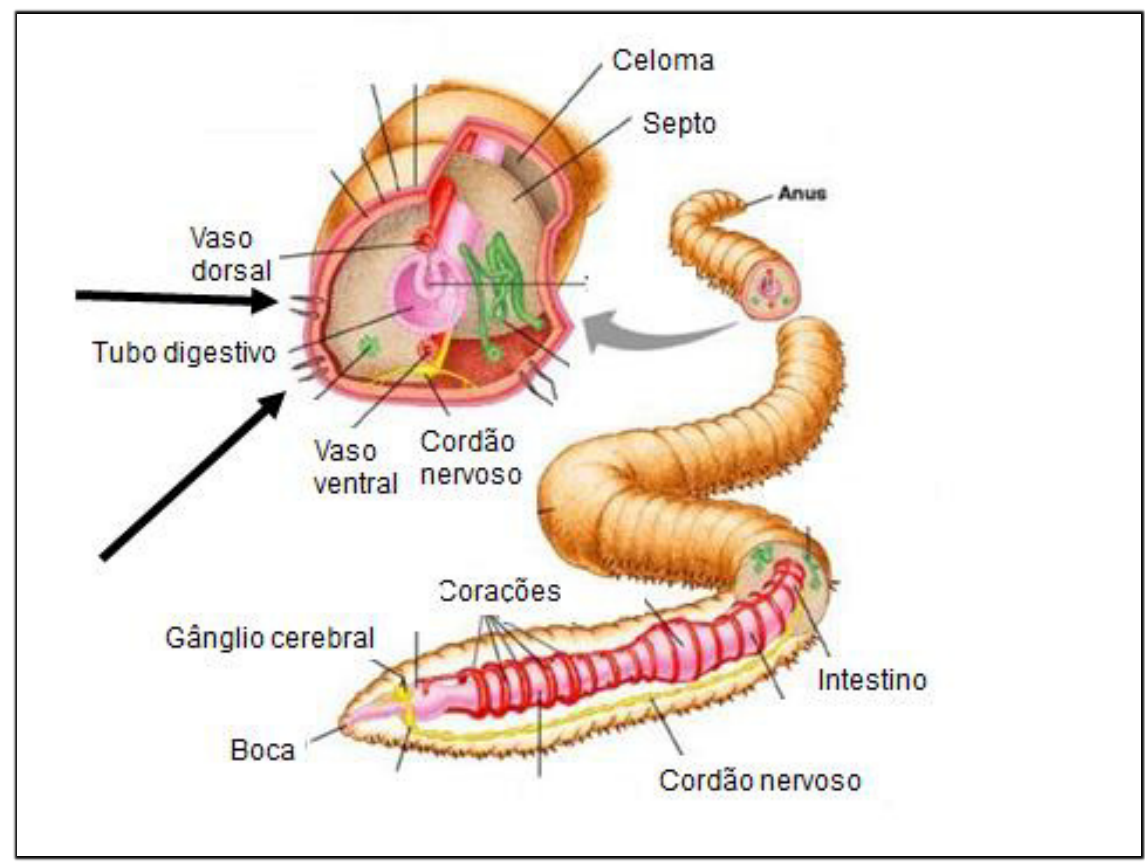

Figura 3 - Exemplo de Imagem Constitutiva.

A Figura 12 mostra disposição de seres vivos em uma linha do tempo. Ela também é uma imagem Processual, pois mostra o processo evolutivo representado pelas setas verdes. 


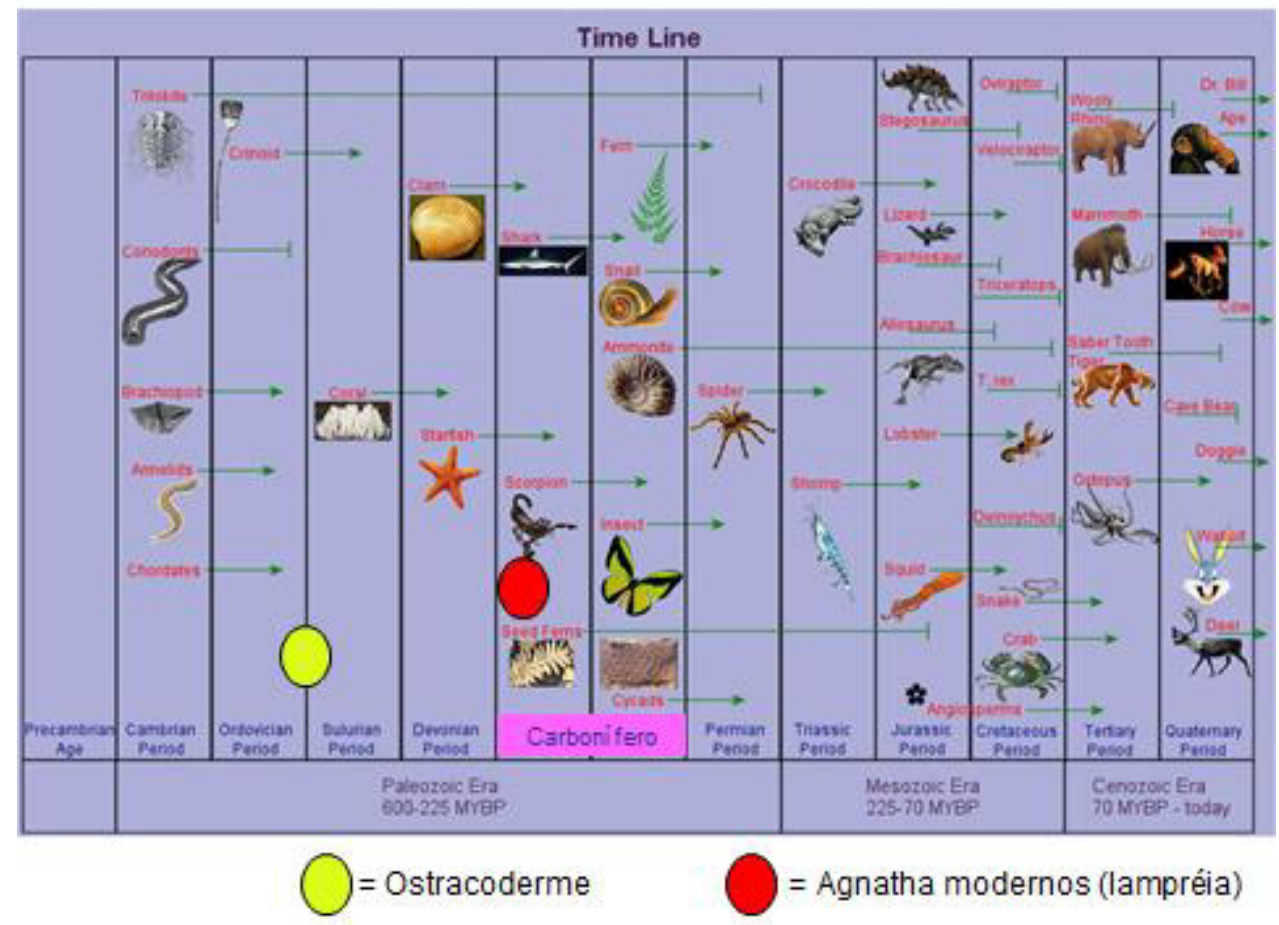

Figura 12 - Exemplo de Imagem Organizacional.

A imagem abaixo (Figura 13) explicar a reprodução dos esquilos ao longo de várias gerações, sendo, portanto, uma imagem Processual. Também é uma imagem Comparativa, a medida que compara o aumento da população dos esquilo pequenos com os grandes.

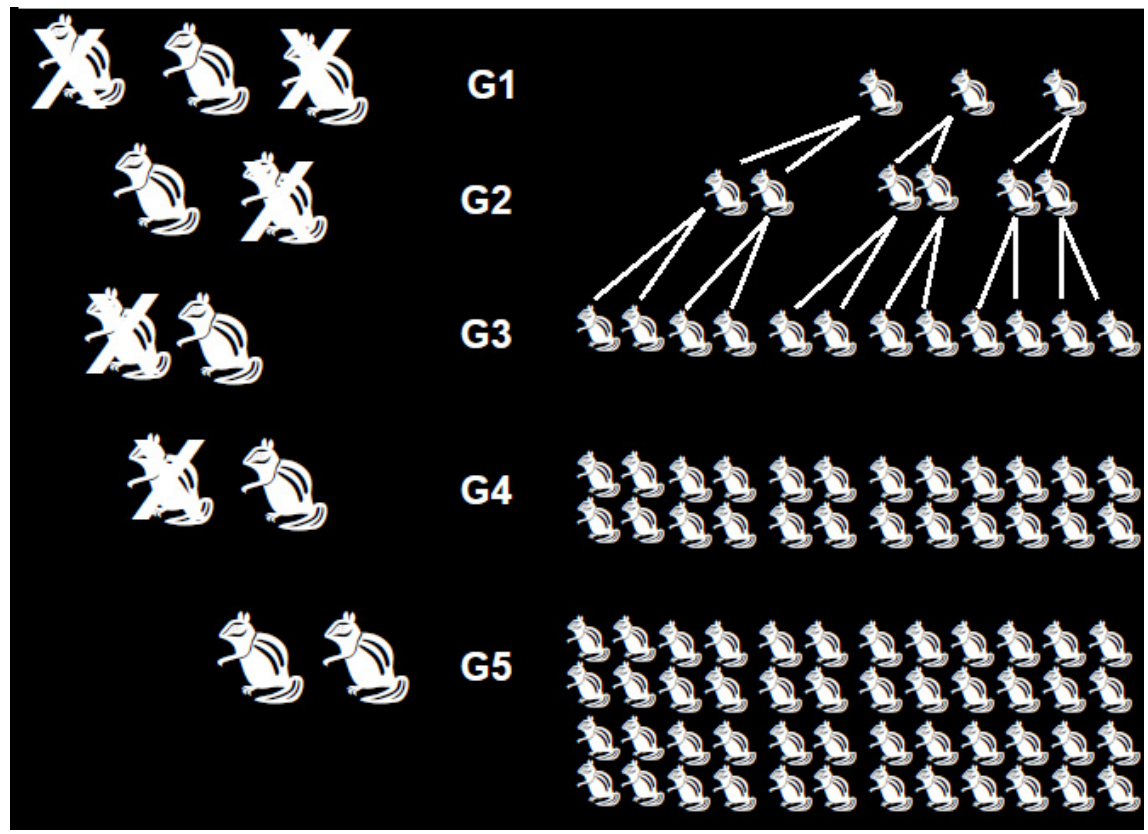

Figura 13 - Exemplo de Imagem Processual. 


\section{ReSUltados e Discussão}

Neste item, apresentamos os dados obtidos na presente investigação referentes aos materiais didáticos apresentados nas disciplinas Diversidade Zoológica e Diversidade Botânica, bem como a análise e discussão de tais dados. Lembramos que foram analisados dois conjuntos de materiais elaborados por professores diferentes no caso da primeira disciplina, denominados como professor A e professor B. Já no caso da segunda disciplina, apenas um conjunto de material foi analisado. Os três conjuntos de materiais analisados estão disponíveis em anexo na presente dissertação, na forma de arquivos no CD-Rom.

No total, 1727 imagens foram objeto do presente estudo em duas análises distintas: morfológica (tipo, coloração, tamanho e presença de escalas) e funcional, tal como já foi apresentado no item 4.3.2 da presente dissertação. 


\subsection{Análise Morfológica das Imagens dos Materiais Didáticos}

\subsubsection{Disciplina Diversidade Zoológica - Material elaborado pelo Prof. A}

Na parte da disciplina de Diversidade Zoológica ministrada pelo professor A, foi utilizado um total de 482 imagens, que foram classificadas conforme apresentado na Tabela 6.

Tabela 6 - Análise Morfológica das Imagens do Material da Disciplina Diversidade Zoológica (Prof. A).

\begin{tabular}{|c|c|c|c|c|c|c|c|c|c|c|}
\hline \multirow[b]{2}{*}{ AULAS } & \multicolumn{4}{|c|}{ Tamanho } & \multirow{2}{*}{ 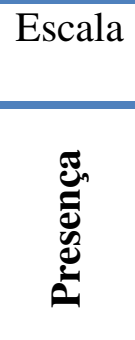 } & \multicolumn{2}{|c|}{ Cores } & \multicolumn{3}{|c|}{ Tipos de Imagens } \\
\hline & 冚 & 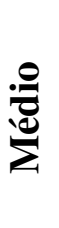 & 莺 & 莺 & & 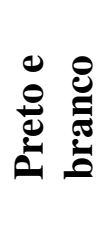 & 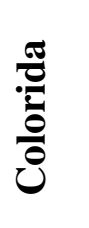 & 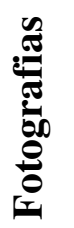 & 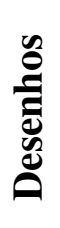 & 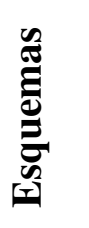 \\
\hline 1 & 22 & 6 & 5 & 11 & 0 & 9 & 35 & 14 & 5 & 25 \\
\hline 2 & 11 & 6 & 8 & 2 & 0 & 4 & 23 & 9 & 2 & 16 \\
\hline 3 & 44 & 6 & 8 & 10 & 0 & 15 & 53 & 24 & 2 & 42 \\
\hline 4 & 49 & 5 & 8 & 6 & 0 & 9 & 59 & 42 & 8 & 18 \\
\hline 5 & 35 & 9 & 11 & 8 & 1 & 10 & 53 & 18 & 5 & 40 \\
\hline 6 & 14 & 4 & 5 & 6 & 2 & 4 & 25 & 15 & 3 & 11 \\
\hline 7 & 55 & 17 & 14 & 5 & 3 & 27 & 64 & 52 & 5 & 34 \\
\hline 8 & 66 & 14 & 9 & 3 & 2 & 36 & 56 & 43 & 9 & 40 \\
\hline TOTAL & 296 & 67 & 68 & 51 & 8 & 114 & 368 & 217 & 39 & 226 \\
\hline
\end{tabular}

Podemos perceber pouca preocupação com as escalas, sendo que essas aparecem apenas em oito imagens, o que equivale a 1,7 \% do total (Tabela 6). Esse é um dado a ser destacado, pois a situação ideal seria que as escalas estivessem mais presentes, uma vez que, seu uso é de extrema importância para a classificação dos seres vivos e, portanto, a compreensão da biodiversidade.

O número de imagens pequenas corresponde a $61 \%$ de todas as utilizadas durante as aulas, enquanto cada um dos demais tamanhos não passa de $15 \%$ das imagens (Tabela 6 , Gráfico 1). 


\section{冈Pequeno $\boxminus$ Médio Grande $\square$ Muito Grande}

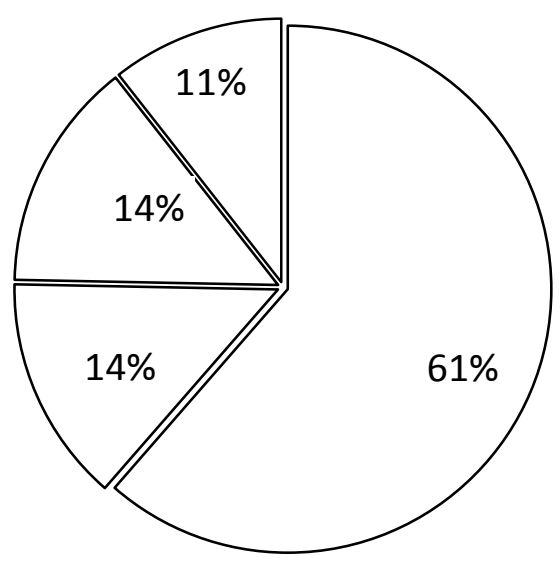

Gráfico 1 - Tamanho das imagens analisadas a partir do material do Prof. A da disciplina Diversidade Zoológica.

Considerando o tipo de imagens, podemos verificar que as do tipo Fotográfica (47\%) e desenho (45\%) superam as do tipo esquemáticas, como gráficos, tabelas e cladogramas, sendo maior o uso de fotografias (Tabela 6, Gráfico 2). Em relação à coloração: a maioria das imagens, $76 \%$, é colorida (Tabela 6, Gráfico 3).

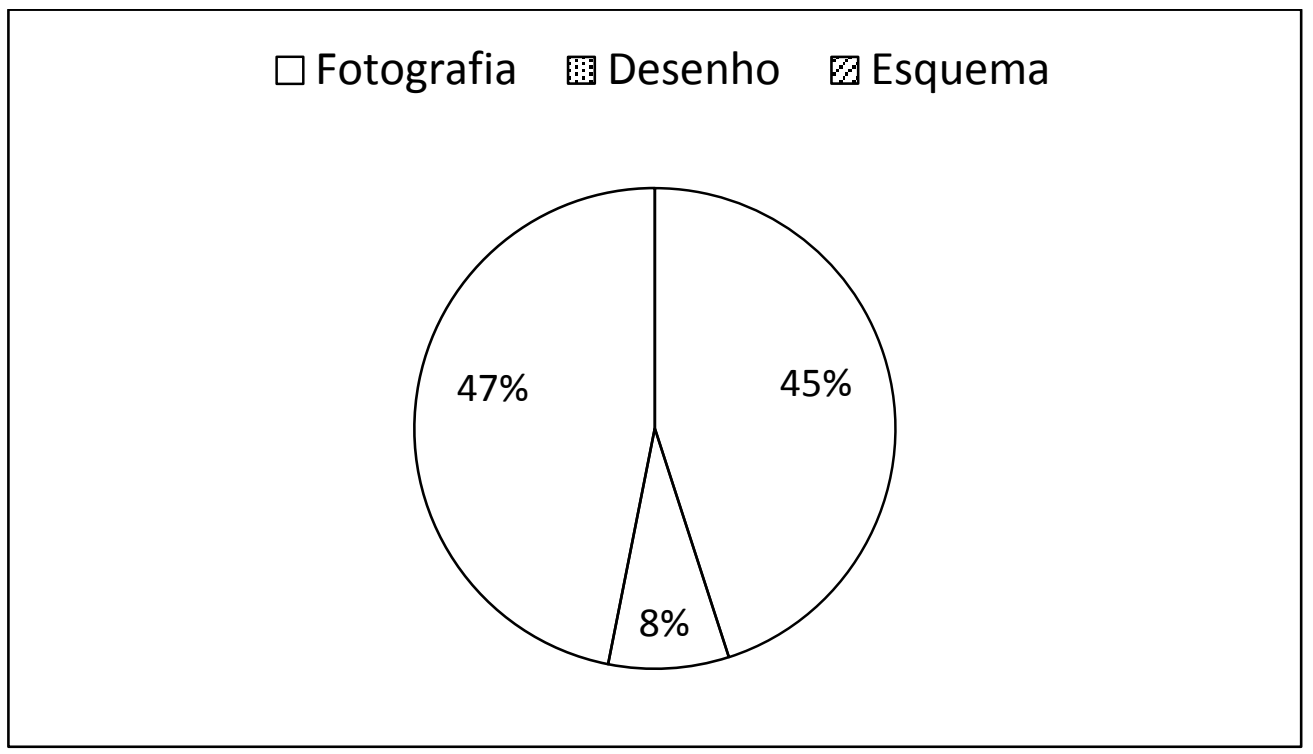

Gráfico 2 - Tipo das imagens analisadas a partir do material do Prof. A da disciplina Diversidade Zoológica. 


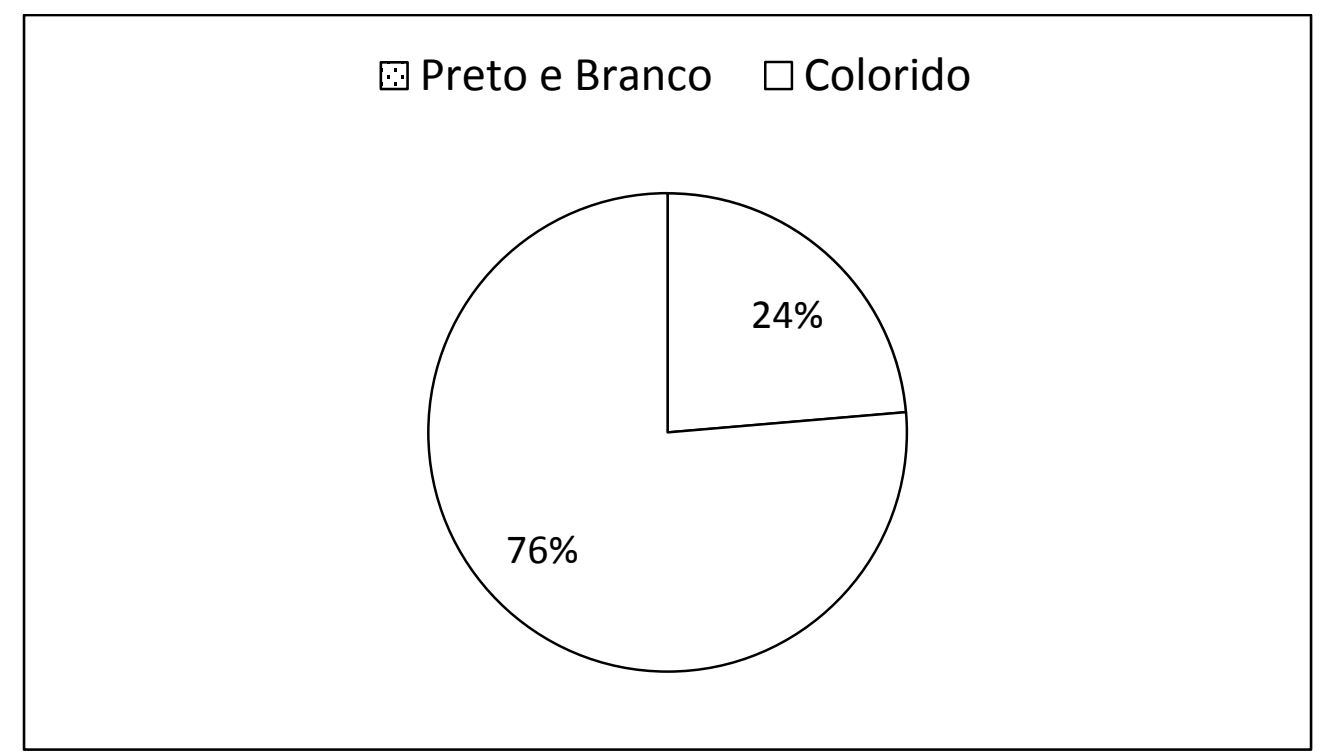

Gráfico 3 - Coloração das imagens analisadas a partir do material do Prof. A da disciplina Diversidade Zoológica. 
5.1.2 Disciplina Diversidade Zoológica - Material elaborado pelo Prof. B

O professor B, assim como o Prof. A, utiliza poucas imagens com escala, sendo apenas 26 em um total de 750 (Tabela 7). Isso representa apenas 3,4\% das imagens, uma porcentagem maior que do Prof. A, porém ainda muito reduzida.

Tabela 7 - Análise Morfológica das Imagens do Material da Disciplina Diversidade Zoológica (Prof. B).

\begin{tabular}{|c|c|c|c|c|c|c|c|c|c|c|}
\hline \multirow[b]{2}{*}{ AULAS } & \multicolumn{4}{|c|}{ Tamanho } & \multirow{2}{*}{ 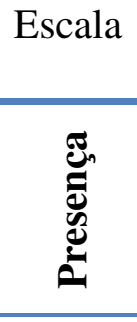 } & \multicolumn{2}{|c|}{ Cores } & \multicolumn{3}{|c|}{ Tipos de Imagens } \\
\hline & 这 & 胥 & 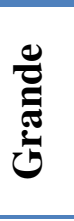 & 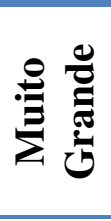 & & 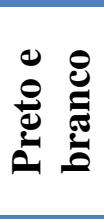 & $\frac{\pi}{0}$ & 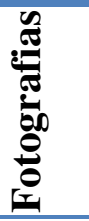 & 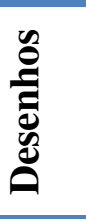 & 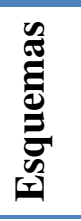 \\
\hline 1 & 23 & 8 & 15 & 81 & 7 & 12 & 115 & 92 & 10 & 25 \\
\hline 2 & 42 & 28 & 19 & 80 & 8 & 29 & 140 & 99 & 25 & 45 \\
\hline 3 & 25 & 18 & 19 & 56 & 1 & 19 & 99 & 68 & 26 & 24 \\
\hline 4 & 47 & 16 & 14 & 68 & 8 & 34 & 111 & 83 & 24 & 38 \\
\hline 5 & 23 & 24 & 19 & 50 & 2 & 25 & 91 & 74 & 21 & 21 \\
\hline 6 & 29 & 30 & 23 & 49 & 0 & 38 & 93 & 58 & 47 & 26 \\
\hline TOTAL & 189 & 124 & 109 & 384 & 26 & 157 & 649 & 474 & 153 & 179 \\
\hline
\end{tabular}

Com relação ao tamanho das imagens utilizadas nas aulas, podemos notar que há uma prevalência de imagens muito grandes (37\%), sendo que cada um dos demais tamanhos ocupam cerca de $20 \%$ das imagens (Tabela 7, Gráfico 4). 


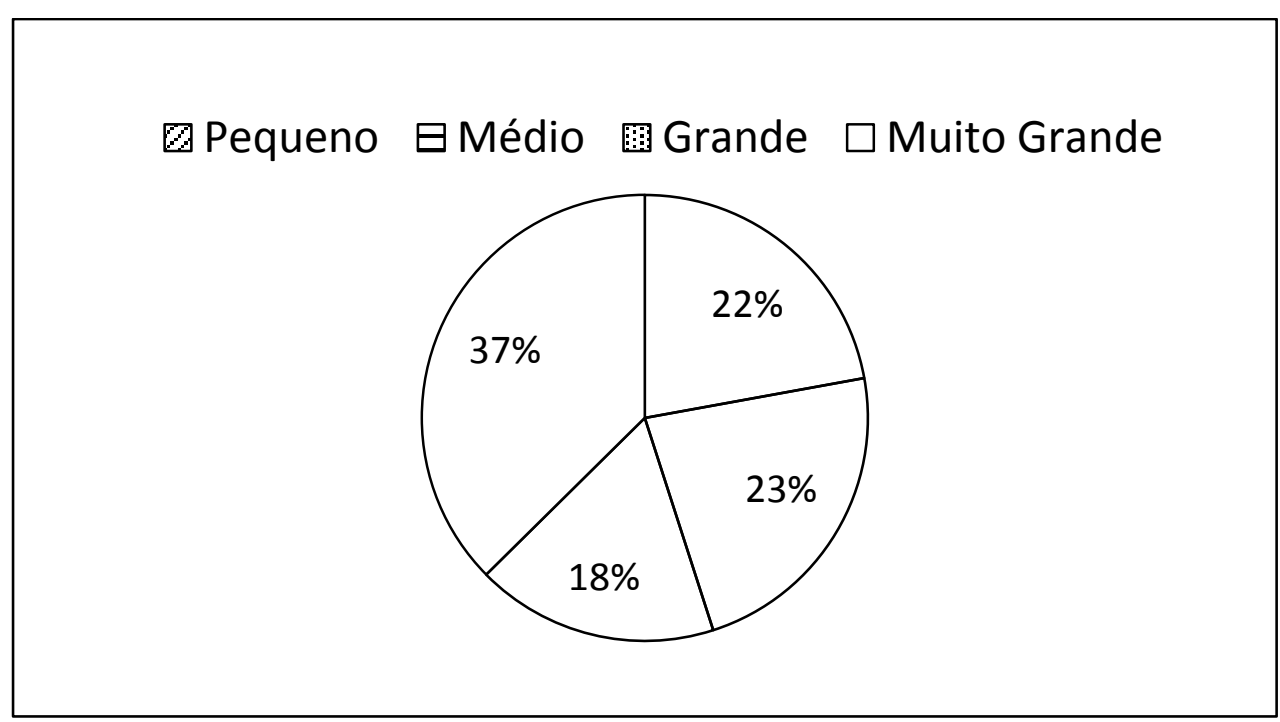

Gráfico 4 - Tamanho das imagens analisadas a partir do material do Prof. B da disciplina Diversidade Zoológica.

Em relação ao tipo de imagens, podemos perceber que há um uso maior do tipo Fotográfica (44\%). Já as imagens do tipo desenho estão percentualmente menos representadas (36\%) do que o observado no material do Prof. A (47\%) (Tabela 7, Gráfico 5). Quanto à coloração das imagens, novamente há mais imagens coloridas (71\%) do que em preto e branco (29\%) (Tabela 7, Gráfico 6).

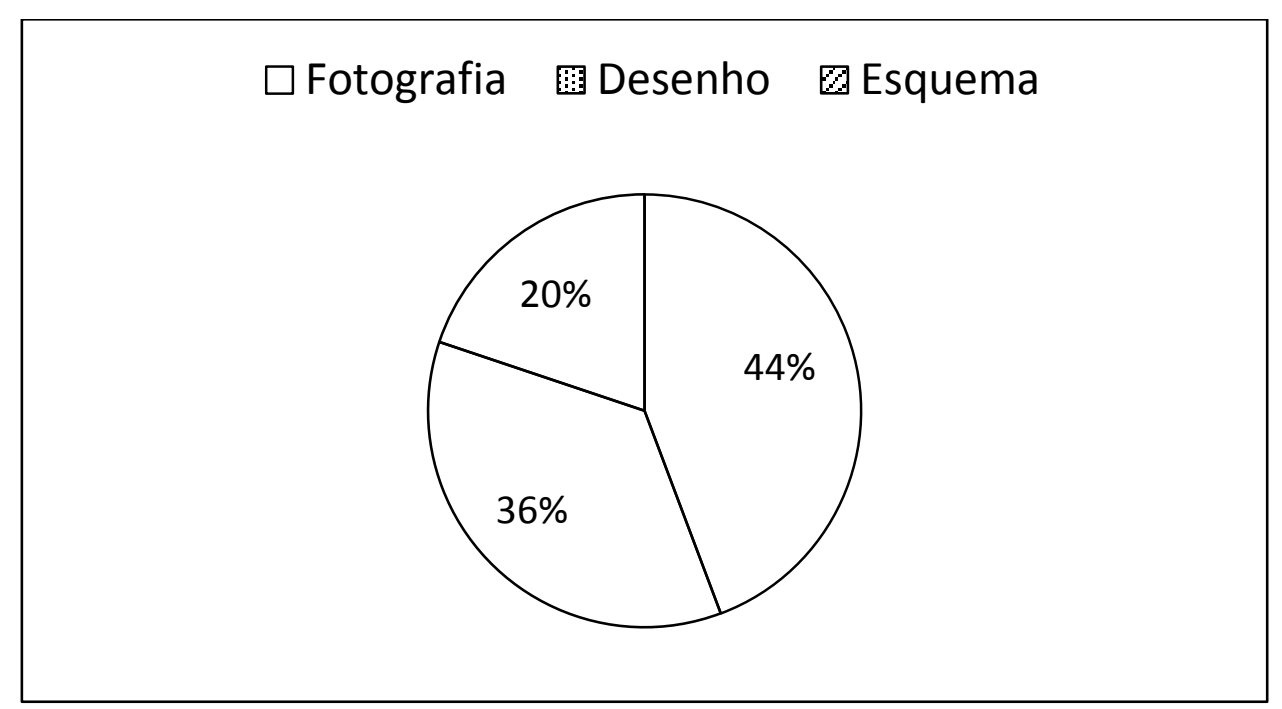

Gráfico 5- Tipo das imagens analisadas a partir do material do Prof. B da disciplina Diversidade Zoológica. 


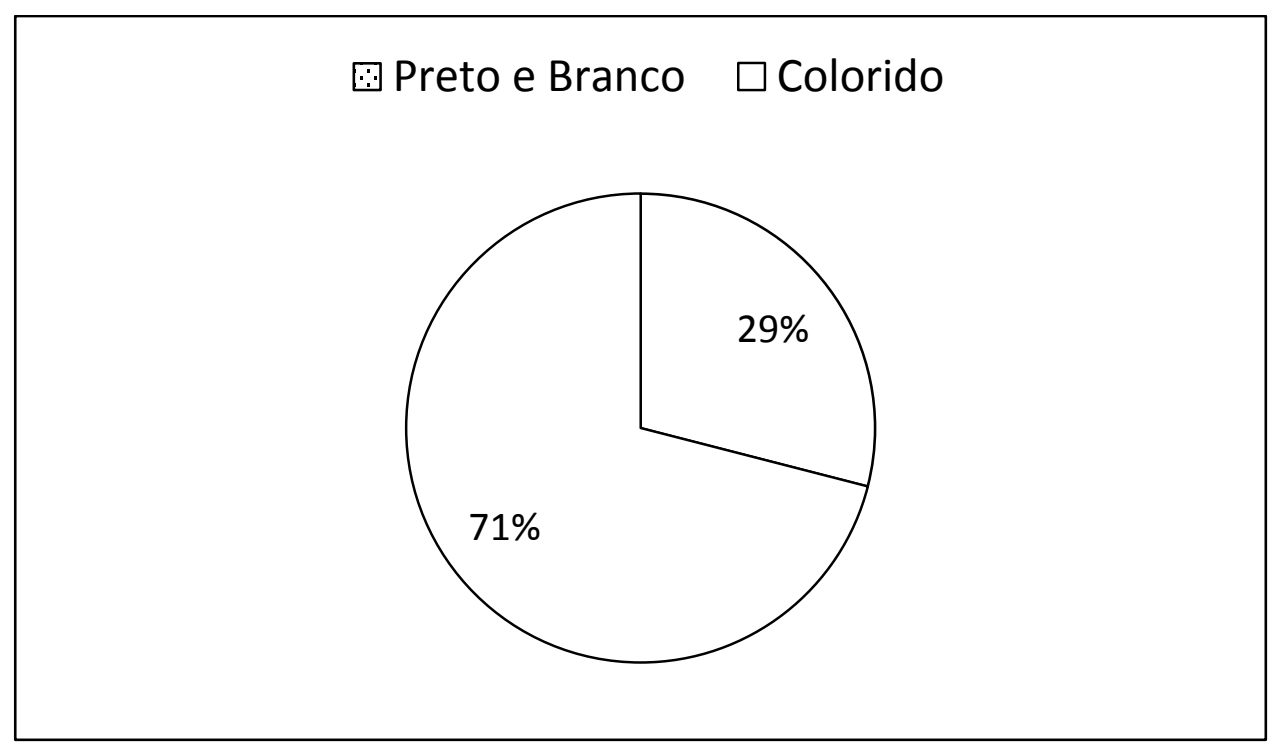

Gráfico 6- Coloração das imagens analisadas a partir do material do Prof. B da disciplina Diversidade Zoológica. 


\subsubsection{Disciplina Diversidade Botânica}

A Tabela 8 apresenta os dados obtidos da análise morfológica do material referente à disciplina de Diversidade Botânica, na qual foram analisadas 369 imagens. Percebe-se novamente um número muito baixo de imagens com escala, apenas 6 imagens.

Tabela 8 - Análise Morfológica das Imagens do Material de Diversidade Botânica.

\begin{tabular}{|c|c|c|c|c|c|c|c|c|c|c|}
\hline \multirow[b]{2}{*}{ Arquivos } & \multicolumn{4}{|c|}{ Tamanho } & \multirow{2}{*}{ 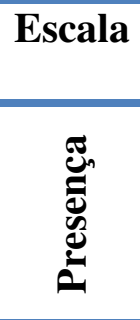 } & \multicolumn{2}{|c|}{ Cores } & \multicolumn{3}{|c|}{$\begin{array}{l}\text { Tipos de } \\
\text { Imagens }\end{array}$} \\
\hline & & 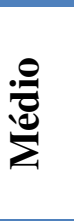 & 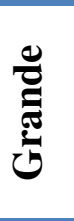 & 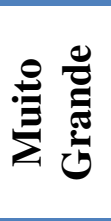 & & 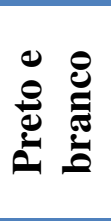 & $\frac{\pi}{0}$ & 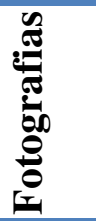 & 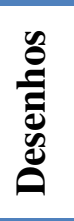 & 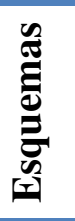 \\
\hline $1(1)$ & 5 & 7 & 17 & 24 & 0 & 16 & 37 & 22 & 21 & 10 \\
\hline $1(2)$ & 15 & 8 & 2 & 1 & 0 & 10 & 16 & 7 & 19 & 0 \\
\hline $1(3)$ & 2 & 3 & 8 & 4 & 1 & 0 & 17 & 17 & 0 & 0 \\
\hline 2 & 4 & 1 & 2 & 4 & 2 & 1 & 10 & 10 & 0 & 1 \\
\hline $3(1)$ & 0 & 2 & 5 & 3 & 0 & 1 & 9 & 6 & 0 & 4 \\
\hline $3(2)$ & 12 & 23 & 7 & 4 & 0 & 10 & 36 & 36 & 2 & 8 \\
\hline $3(3)$ & 11 & 12 & 4 & 4 & 0 & 0 & 31 & 22 & 0 & 9 \\
\hline $3(4)$ & 7 & 3 & 1 & 6 & 0 & 2 & 15 & 11 & 0 & 6 \\
\hline $4(1)$ & 21 & 10 & 3 & 1 & 0 & 2 & 33 & 31 & 3 & 1 \\
\hline $4(2)$ & 9 & 4 & 10 & 23 & 3 & 3 & 43 & 44 & 0 & 2 \\
\hline $4(3)$ & 0 & 1 & 18 & 27 & 0 & 0 & 46 & 46 & 0 & 0 \\
\hline $5(1)$ & 7 & 5 & 5 & 14 & 0 & 3 & 28 & 22 & 0 & 10 \\
\hline TOTAL & 93 & 79 & 82 & 115 & 6 & 48 & 321 & 273 & 45 & 51 \\
\hline
\end{tabular}

Em relação ao tamanho, podemos perceber que há mais imagens "muito grandes" (31\%), que são as aquelas que ocupam todo o espaço da página. Em segundo lugar temos as de tamanho médio (31\%), em terceiro aparecem às imagens pequenas (25\%) e, por último, as imagens grandes (22\%), tal como apresentado no Gráfico 7. 


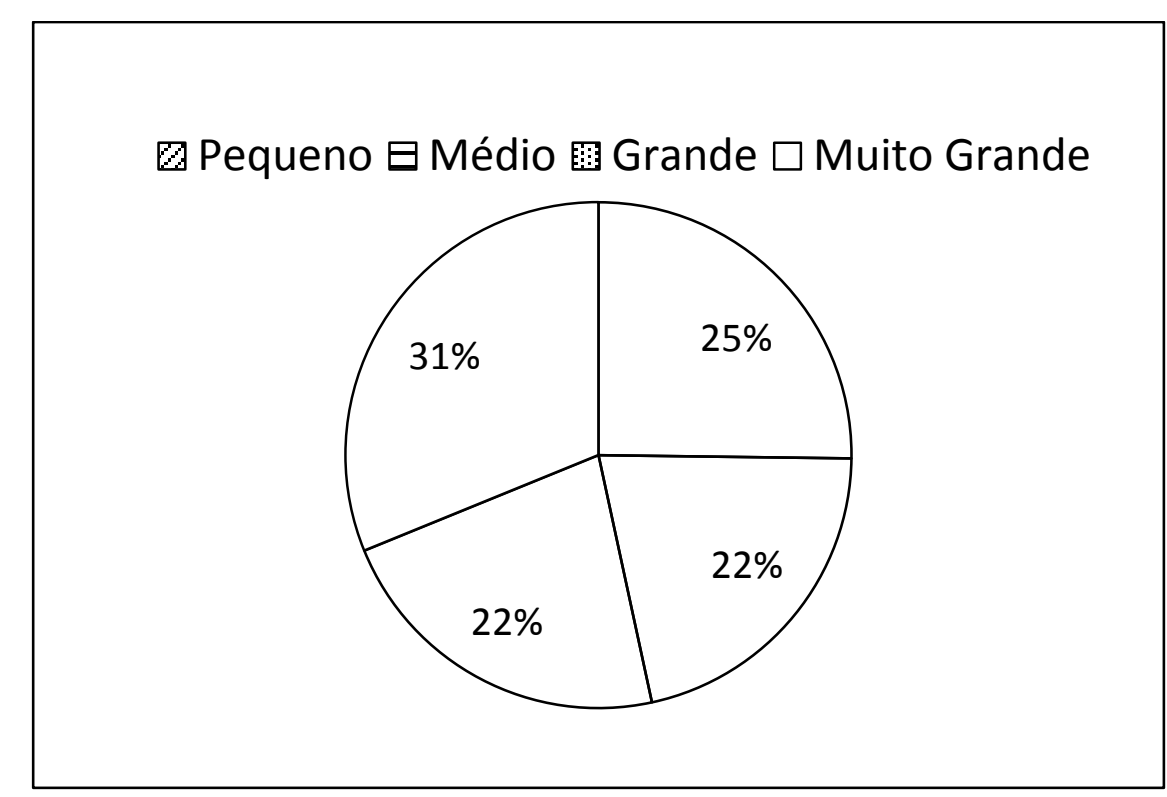

Gráfico 7 - Tamanho das imagens analisadas a partir do material do Prof. de Diversidade Botânica.

Em relação ao tipo de imagens utilizadas, temos que $74 \%$ são fotografias. Os desenhos e esquemas tem um percentual bem mais baixo (14\% e $12 \%$ respectivamente), como é possível ver no Gráfico 8. Tais dados evidenciam uma preferência pelas imagens classificadas como nível 9 da escala de Moles (1981). Tal preferência pode indicar a utilização da imagem como ilustração da aula.

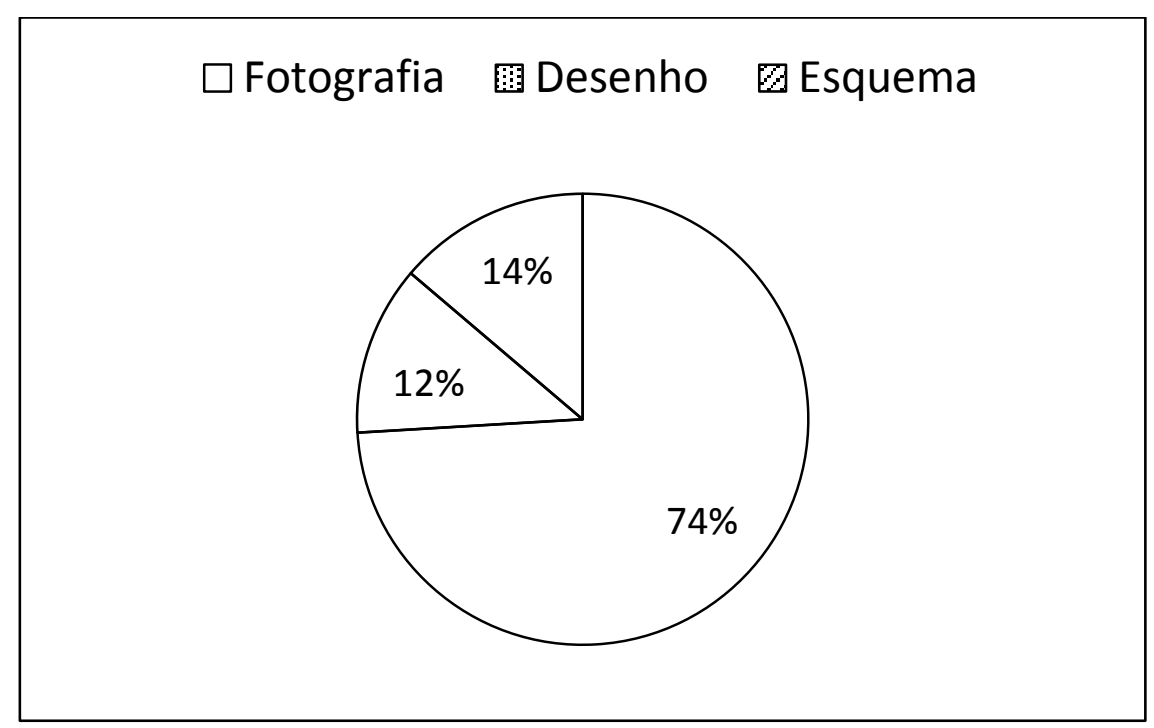

Gráfico 8 - Tipo das imagens analisadas a partir do material do Prof. de Diversidade Botânica. 
Em relação à coloração, 87\% das imagens apresentadas são coloridas, outro indício de aproximação com o real. As imagens em preto e branco são, em sua maioria, esquemas e desenhos (Gráfico 9).

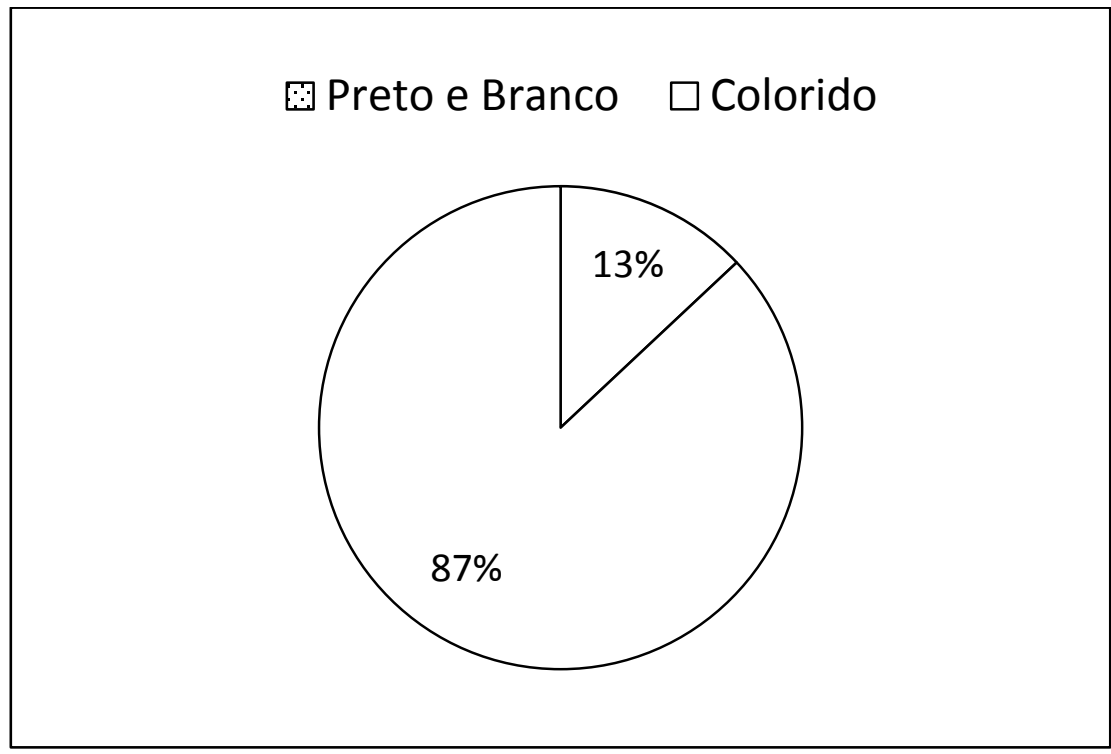

Gráfico 9 - Coloração das imagens analisadas a partir do material do Prof. de Diversidade Botânica. 


\subsubsection{Discutindo a Análise Morfológica}

Iniciamos nossa discussão ressaltando que os trabalhos sobre utilização de imagens no ensino de ciências ainda são relativamente restritos, sendo necessário ampliar as pesquisas na área. Não fomos capazes de obter trabalhos semelhantes ao nosso, que analisa imagens apresentadas durante aulas. Assim, as relações que estabelecemos com a literatura são realizadas com base em trabalhos que investigam imagens, porém em livros didáticos. Nesse cenário, ressaltamos que as comparações são limitadas, devido à natureza diversa das fontes de imagens.

Destacamos ainda que a presente pesquisa caracteriza-se como um estudo de caso Dessa forma, não podemos generalizar seus achados. No entanto, julgamos o estudo pertinente para ampliar os conhecimentos na área, uma vez que permite conhecer uma dada realidade e compará-la, futuramente, com situações distintas que venham a ser investigadas.

Pudemos encontrar alguns padrões ao analisar as 1727 imagens utilizadas pelos três docentes do curso de Licenciatura em Ciências da Natureza, conforme detalharemos a seguir.

Há uma evidente preferência por imagens coloridas: $76 \%$ das imagens de Diversidade Zoológica - Prof. A, 71\% das imagens de Diversidade Zoológica - Prof. B e 87\% das imagens de Diversidade Botânica. Tais dados estão de acordo com os obtidos por Jotta e Carneiro (2005), que analisaram 190 imagens contidas em oito livros didáticos de Biologia e obtiveram um total de aproximadamente $93 \%$ das imagens coloridas. Sebata et. al. (2005), ao analisar 69 imagens de um livro didático de química, notaram que todas as imagens eram coloridas. Apesar do pequeno número de trabalhos científicos, podemos perceber que parece existir uma preferência por imagens coloridas no campo do ensino das áreas científicas.

Outro padrão relevante refere-se ao tipo de imagem, pois em todos os materiais didáticos houve um alto percentual do uso de imagens do tipo fotográfica (45\% do Prof. A, 44\% do Prof. B de Diversidade Zoologia e 74\% das imagens de Diversidade Botânica). Fazendo uma média para os matérias dos três professores, obtemos $56 \%$ das imagens Fotográficas (Gráfico 10). Tais dados estão de acordo com os obtidos por Sebata et. al. (2005), cujo material analisado continha $78 \%$ das imagens Fotográficas. Já nos livros analisados por Jotta e Carneiro (2005), há uma maior ocorrência de imagens do tipo 
esquemática (aproximadamente $75 \%$ das imagens). Na presente pesquisa, as imagens esquemáticas ficaram em segundo lugar, com 31\% do total. O Prof. A de Diversidade Zoológica foi o que mais utilizou esse tipo de imagem, apresentando $47 \%$ das imagens.

Podemos inferir que a maior ocorrência de imagens do tipo Fotográficas neste estudo relacione-se com o fato de abordarmos especificamente imagens de disciplinas voltadas para o campo da biodiversidade. Dessa forma, parece que aquelas imagens que exemplificam organismos estão muito presentes. Já quando se aborda toda a Biologia, como no caso do estudo de Jotta e Carneiro (2005), a situação é diferente, existindo uma maior variedade de tipos de imagens.

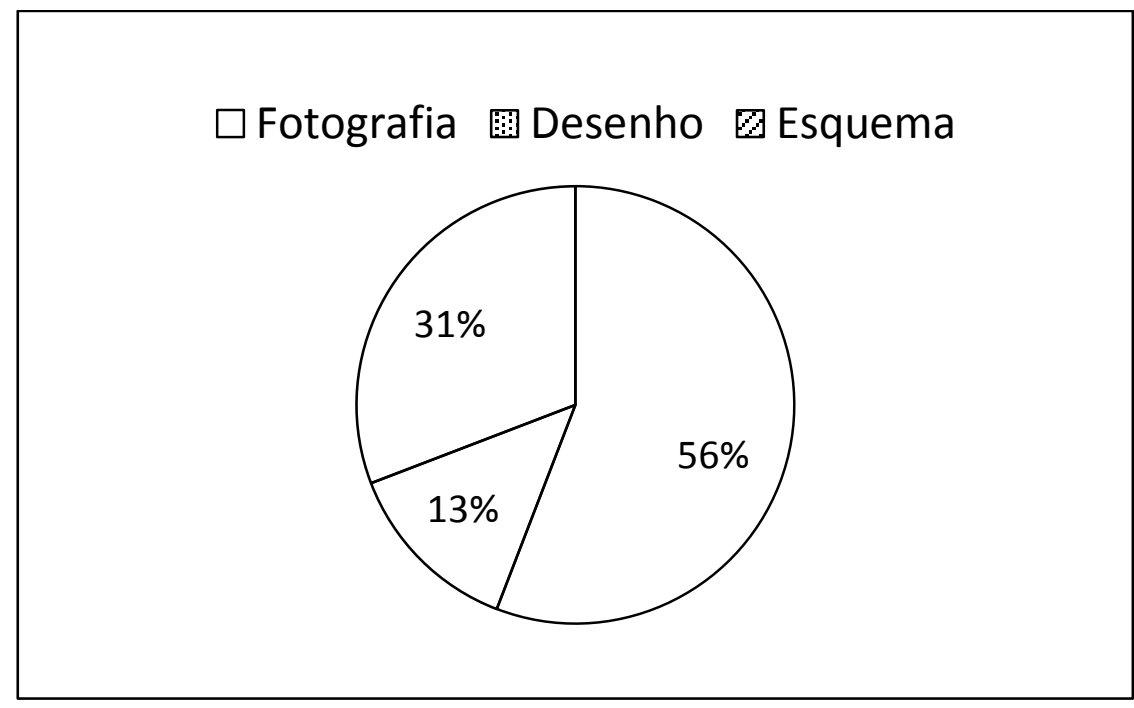

Gráfico 10 - Total de tipos de imagens analisadas a partir dos materiais dos três docentes.

Em relação ao tamanho, vemos uma grande semelhança na escolha de tamanhos entre o Prof. B de Diversidade Zoológica e o professor de Diversidade Botânica (Gráficos 4 e 7). Já o Prof. A de Diversidade Zoológica tem um preferência pela imagens de menor tamanho, com $61 \%$ sendo imagens pequenas, com um maior número de imagens por tela. Aqui não nos cabe fazer juízo de valor sobre qual a melhor alternativa didática, apenas constatamos que os professores apresentam estilos diferentes na elaboração de seus materiais didáticos, dois com preferência por telas com imagens maiores e outro com preferência por telas com imagens de tamanho menor. 
Tabela 9 - Distribuição de Imagens dos Materiais Didáticos Analisados.

\begin{tabular}{|c|c|c|c|}
\hline Disciplinas & $\begin{array}{c}\text { Quantidade total } \\
\text { de páginas/slides }\end{array}$ & $\begin{array}{c}\text { Número total de } \\
\text { Imagens }\end{array}$ & $\begin{array}{c}\text { Proporção de imagens } \\
\text { por página (média) }\end{array}$ \\
\hline $\begin{array}{c}\text { Diversidade } \\
\text { Zoológica Prof. A }\end{array}$ & 225 & 369 & 1,64 \\
\hline $\begin{array}{c}\text { Diversidade } \\
\text { Zoológica Prof. B }\end{array}$ & 226 & 482 & 2,13 \\
\hline $\begin{array}{c}\text { Diversidade } \\
\text { Botânica }\end{array}$ & 614 & 806 & 1,31 \\
\hline
\end{tabular}

Constatamos que há um número maior de imagens do que telas nos materiais didáticos analisados (Tabela 9). A pesquisa de Sebata et. al. (2005) também constatou uma grande presença de imagens no livro analisado, pois cerca de $70 \%$ da área das páginas analisadas eram ocupadas por imagens. Tais dados indicam a valorização das imagens por parte de quem prepara o material didático para o ensino-aprendizagem de Ciência, seguindo a importância desse recurso visual na construção do conhecimento científico propriamente dito, como já evidenciamos na justificativa do presente trabalho.

A importância das imagens no ensino-aprendizagem de ciências já é bem reconhecida na literatura, como ressalta Isabel Martins et. all (2005):

\footnotetext{
"Imagens são importantes recursos para a comunicação de ideias científicas. No entanto, além da indiscutível importância como recursos para a visualização, contribuindo para a inteligibilidade de diversos textos científicos, as imagens também desempenham um papel fundamental na constituição das ideias científicas e na sua conceitualização".
}

Essa importância possivelmente deva-se às diversas funções didáticas que as imagens podem apresentar, tais como:

- prender a atenção do aluno;

- facilitar a compreensão do texto;

- despertar interesse para a aprendizagem;

- auxiliar o aluno a construir um quadro de representação de conceitos e ideias

(MARTINS; GOUVÊA, 2001); (PERALES; JIMÉNEZ,2002). 
Assumindo a importância das imagens no ensino de ciências e partindo da constatação de que elas são amplamente utilizadas pelos sujeitos da presente pesquisa em suas aulas, emergem outras questões a serem discutidas:

Essa grande quantidade de imagens é bem explorada durante as aulas? Todo seu potencial é contemplado? Para responder a tais indagações, seria necessário acompanhar cuidadosamente as aulas, registrar sistematicamente os padrões de utilização de imagens e analisar os resultados.

Deixamos aqui essa proposta para futuras investigações que visem dar continuidade ao presente trabalho. No entanto, com base nas poucas observações realizadas para subsidiar a presente pesquisa (como descrito no item 4.3.2 da Metodologia), já podemos notar que as imagens são exploradas, normalmente, de forma superficial. Parece não haver tempo suficiente para deixar que os alunos observem cada imagem atentamente. Assim, muitas vezes, elas acabam sendo apenas mostradas rapidamente e poucos comentários ou explicações sobre ela são feitos.

Percebemos, durante essas observações preliminares, que, em geral, as imagens nas quais os professores empregam mais tempo nas explicações (e permitem maior tempo de observação dos alunos) são as esquemáticas, principalmente os gráficos. No entanto, quanto às do tipo Fotográficas, são muitas vezes apresentadas tão rapidamente que mal é possível identificar todos os elementos presentes nelas, principalmente em telas com mais de uma imagem. Em geral, os professores observados não comentam muito sobre as fotografias, limitando-se a apresentá-las com frases do tipo "Vejam, essa árvore é uma Araucária" ou "Aqui temos um exemplo de sapo do gênero Dendrobates". Como ressaltado anteriormente, um estudo mais aprofundado investigando a interação dos professores com as imagens seria necessário para confirmar esse padrão de utilização detectado com base nas observações iniciais realizadas no presente trabalho. 


\subsection{Análise Funcional das Imagens do Material Didático}

\subsubsection{Disciplina Diversidade Zoológica - Material elaborado pelo Prof. A}

No material do Prof. A (Diversidade Zoológica), 40 imagens são multifuncionais, o que representa $8,2 \%$ do total. Temos um elevado número de imagens cujas funções são Ilustrativa, Constitutiva ou Comparativa, enquanto as categorias Numérica e Decorativa são pouco utilizadas. As imagens Ilustrativas são as mais frequentes, com 153 ocorrências (29\%). As Constitutivas aparecem em segundo, com 148 imagens (28\%) e as Comparativas em terceiro lugar, com 120 imagens (22\%). As demais categorias aparecem em menos de $10 \%$ do total das imagens (Tabela 10, Gráfico 11).

Tabela 10- Análise Funcional das Imagens do Material Didático do Prof. A da Disciplina Diversidade Zoológica.

\begin{tabular}{|c|c|c|c|c|c|c|c|c|c|c|c|}
\hline \multirow{2}{*}{$\frac{\infty}{3}$} & \multirow{2}{*}{ 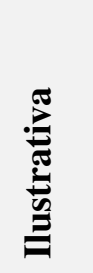 } & \multirow{2}{*}{ 泀 } & \multirow{2}{*}{ 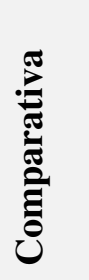 } & \multirow{2}{*}{ 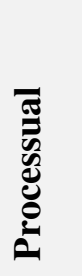 } & \multirow{2}{*}{ 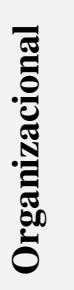 } & \multirow{2}{*}{ 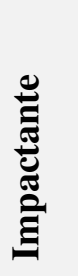 } & \multirow{2}{*}{ 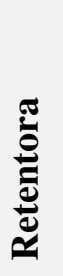 } & \multirow[b]{2}{*}{ 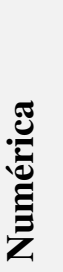 } & \multirow{2}{*}{ 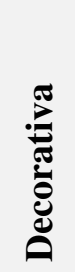 } & \multicolumn{2}{|c|}{ Multifuncional } \\
\hline & & & & & & & & & & $\begin{array}{l}\text { Dupla } \\
\text { função }\end{array}$ & $\begin{array}{l}\text { Tripla } \\
\text { função }\end{array}$ \\
\hline 1 & 1 & 2 & 24 & 1 & 21 & 0 & 3 & 0 & 0 & 8 & 1 \\
\hline 2 & 10 & 12 & 0 & 8 & 0 & 0 & 0 & 0 & 0 & 3 & 0 \\
\hline 3 & 16 & 27 & 15 & 9 & 0 & 0 & 1 & 0 & 1 & 0 & 0 \\
\hline 4 & 11 & 16 & 42 & 7 & 0 & 0 & 4 & 0 & 0 & 6 & 3 \\
\hline 5 & 11 & 32 & 15 & 11 & 0 & 1 & 1 & 0 & 0 & 6 & 1 \\
\hline 6 & 5 & 7 & 13 & 4 & 2 & 3 & 0 & 0 & 0 & 3 & 1 \\
\hline 7 & 53 & 22 & 6 & 8 & 2 & 2 & 1 & 1 & 1 & 4 & 0 \\
\hline 8 & 46 & 30 & 5 & 3 & 7 & 6 & 0 & 0 & 0 & 5 & 0 \\
\hline TOTAL & 153 & 148 & 120 & 51 & 32 & 12 & 10 & 1 & 0 & 35 & 5 \\
\hline
\end{tabular}




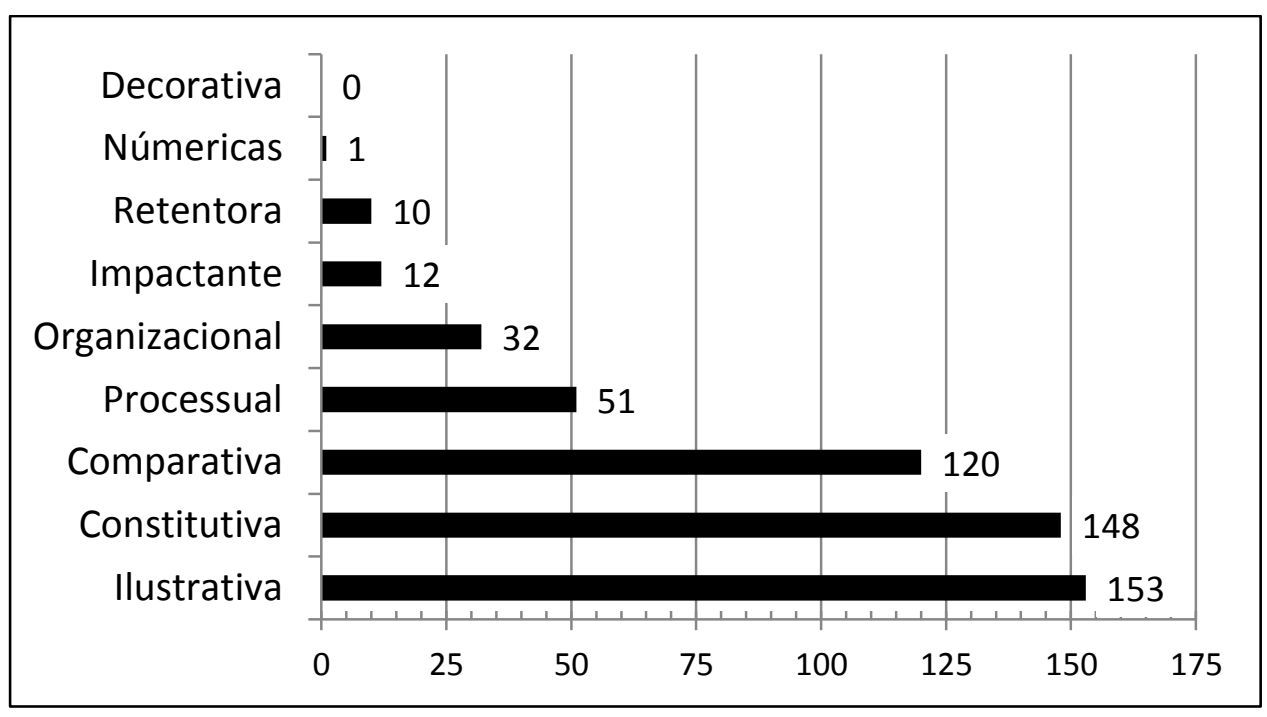

Gráfico 11 - Análise funcional: categorias das imagens do material do Prof. A da disciplina Diversidade Zoológica. 
Comparando-se o Prof. B com o A, podemos notar que o segundo utiliza menos imagens multifuncionais (Tabelas 10 e 11).

Tabela 11 - Análise Funcional das Imagens do Material Didático da Disciplina de Diversidade Zoológica (Prof. B).

\begin{tabular}{|c|c|c|c|c|c|c|c|c|c|c|c|}
\hline \multirow{2}{*}{$\frac{n}{3}$} & \multirow{2}{*}{ 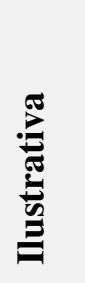 } & \multirow{2}{*}{ 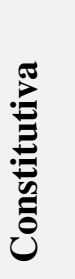 } & \multirow{2}{*}{ 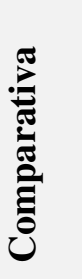 } & \multirow{2}{*}{ 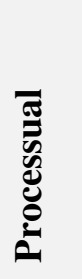 } & \multirow{2}{*}{ 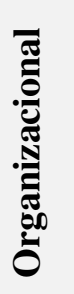 } & \multirow{2}{*}{ 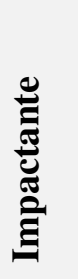 } & \multirow{2}{*}{ 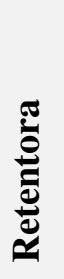 } & \multirow{2}{*}{ 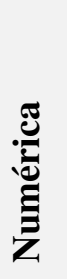 } & \multirow{2}{*}{ 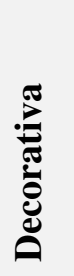 } & \multicolumn{2}{|c|}{ Multifuncional } \\
\hline & & & & & & & & & & $\begin{array}{l}\text { Dupla } \\
\text { função }\end{array}$ & $\begin{array}{l}\text { Tripla } \\
\text { função }\end{array}$ \\
\hline 1 & 60 & 18 & 11 & 0 & 2 & 8 & 21 & 1 & 6 & 0 & 0 \\
\hline 2 & 65 & 15 & 25 & 19 & 7 & 15 & 21 & 1 & 9 & 8 & 0 \\
\hline 3 & 42 & 19 & 7 & 3 & 2 & 20 & 20 & 1 & 6 & 2 & 0 \\
\hline 4 & 49 & 17 & 23 & 28 & 0 & 24 & 10 & 1 & 7 & 14 & 0 \\
\hline 5 & 37 & 10 & 38 & 15 & 0 & 7 & 9 & 0 & 1 & 1 & 0 \\
\hline 6 & 44 & 18 & 45 & 16 & 12 & 3 & 6 & 2 & 3 & 18 & 0 \\
\hline TOTAL & 297 & 97 & 149 & 81 & 23 & 77 & 87 & 6 & 32 & 43 & $\mathbf{0}$ \\
\hline
\end{tabular}

Observando o Gráfico 12, podemos verificar que, assim como o Prof. A, o Prof. B também utiliza um maior número de imagens Ilustrativas. A segunda maior ocorrência é de imagens de função Comparativa, com 149 imagens (18\%), seguida pelas imagens Constitutivas, com 97 imagens (11\%) e, Retentoras, com 87 imagens (10\%). As demais funções aparecem com ocorrências menores de $10 \%$ cada uma. 


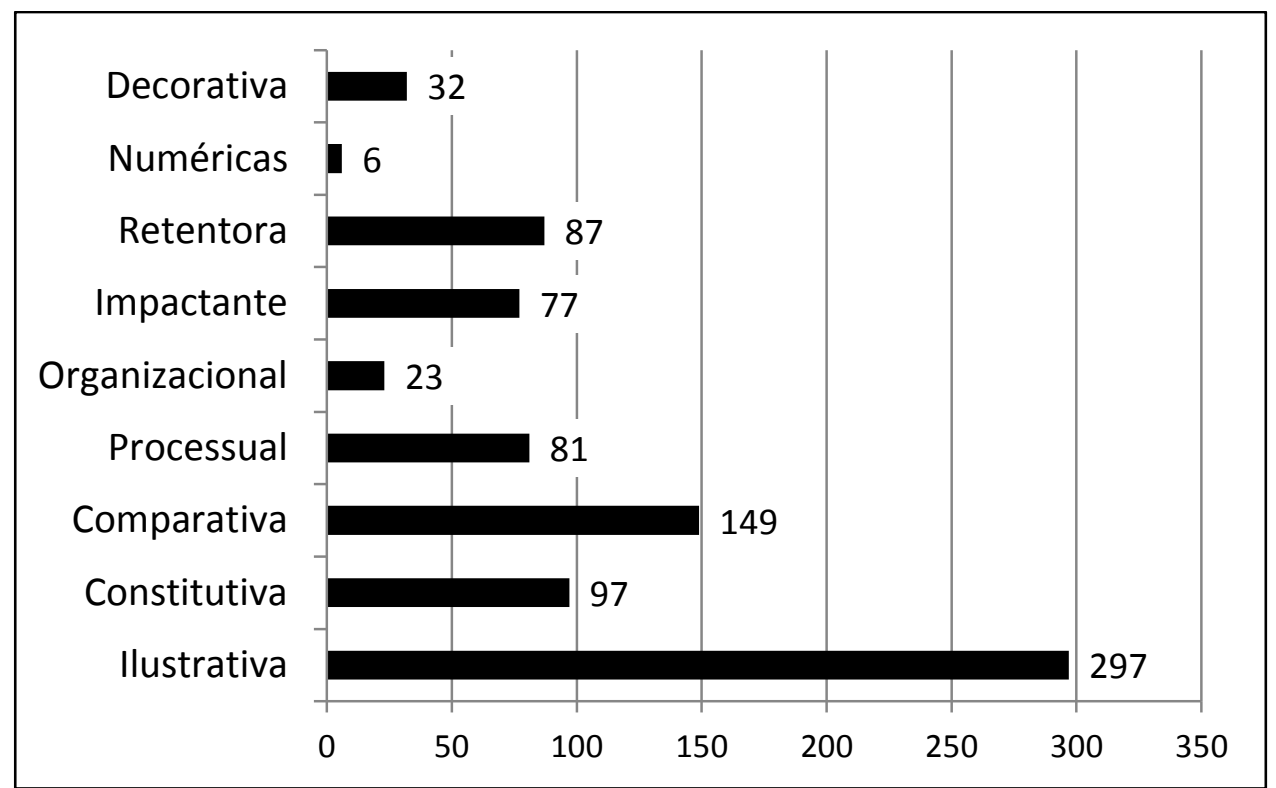

Gráfico 12- Análise funcional: categorias das imagens do material do Prof. B da disciplina Diversidade Zoológica. 


\subsubsection{Disciplina Diversidade Botânica}

Este professor utiliza intensamente as imagens do tipo Ilustrativa, que representam $75 \%$ de todas as imagens, com 594 ocorrências (Tabela 12, Gráfico 13). O uso de imagens de múltiplas funções foi o maior dentre os materiais dos três professores analisados no presente trabalho, com 52 imagens (6,3\% do total).

Tabela 12 - Análise Funcional das imagens do material da Disciplina do Prof. de Diversidade Botânica.

\begin{tabular}{|c|c|c|c|c|c|c|c|c|c|c|c|}
\hline \multirow{2}{*}{$\frac{\infty}{3}$} & \multirow{2}{*}{ 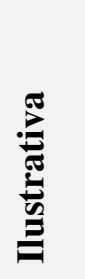 } & \multirow{2}{*}{ 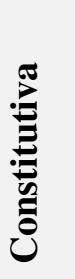 } & \multirow{2}{*}{ 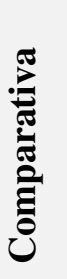 } & \multirow{2}{*}{ 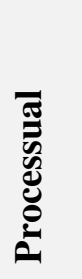 } & \multirow{2}{*}{ 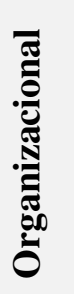 } & \multirow{2}{*}{ 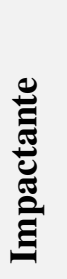 } & \multirow{2}{*}{ 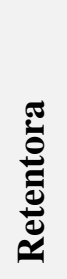 } & \multirow{2}{*}{ } & \multirow{2}{*}{ 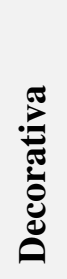 } & \multicolumn{2}{|c|}{ Multifuncional } \\
\hline & & & & & & & & & & $\begin{array}{l}\text { Dupla } \\
\text { função }\end{array}$ & $\begin{array}{l}\text { Tripla } \\
\text { função }\end{array}$ \\
\hline $1(1)$ & 41 & 7 & 3 & 1 & 4 & 0 & 0 & 0 & 1 & 4 & 0 \\
\hline $1(2)$ & 16 & 1 & 9 & 0 & 0 & 0 & 0 & 0 & 0 & 0 & 0 \\
\hline $1(3)$ & 17 & 0 & 0 & 0 & 0 & 0 & 0 & 0 & 0 & 0 & 0 \\
\hline $2(1)$ & 9 & 2 & 0 & 1 & 0 & 0 & 0 & 0 & 0 & 1 & 0 \\
\hline $3(1)$ & 6 & 4 & 4 & 1 & 0 & 0 & 0 & 0 & 0 & 6 & 1 \\
\hline $3(2)$ & 36 & 5 & 2 & 5 & 1 & 0 & 0 & 0 & 0 & 1 & 1 \\
\hline 3(3) & 23 & 4 & 2 & 6 & 0 & 0 & 0 & 0 & 0 & 4 & 0 \\
\hline $3(4)$ & 11 & 7 & 0 & 3 & 0 & 0 & 0 & 0 & 0 & 4 & 0 \\
\hline $4(1)$ & 32 & 2 & 0 & 0 & 1 & 0 & 0 & 0 & 0 & 0 & 0 \\
\hline $4(2)$ & 41 & 2 & 0 & 1 & 0 & 3 & 0 & 0 & 0 & 1 & 0 \\
\hline $5(1)$ & 46 & 0 & 0 & 0 & 0 & 0 & 0 & 0 & 0 & 0 & 0 \\
\hline $5(2)$ & 19 & 10 & 0 & 5 & 1 & 0 & 0 & 0 & 1 & 4 & 0 \\
\hline $6(1)$ & 297 & 44 & 20 & 23 & 7 & 3 & 0 & 0 & 2 & 25 & 0 \\
\hline Total & 594 & 88 & 40 & 46 & 14 & 6 & $\mathbf{0}$ & $\mathbf{0}$ & 4 & 50 & 2 \\
\hline
\end{tabular}


Excluindo-se a categoria de imagens Ilustrativas, nota-se que as demais categorias não passam de 5\% do total cada uma. Imagens Decorativa, Numérica, Retentora, Impactante e Organizacional praticamente não são utilizadas (Gráfico 13).

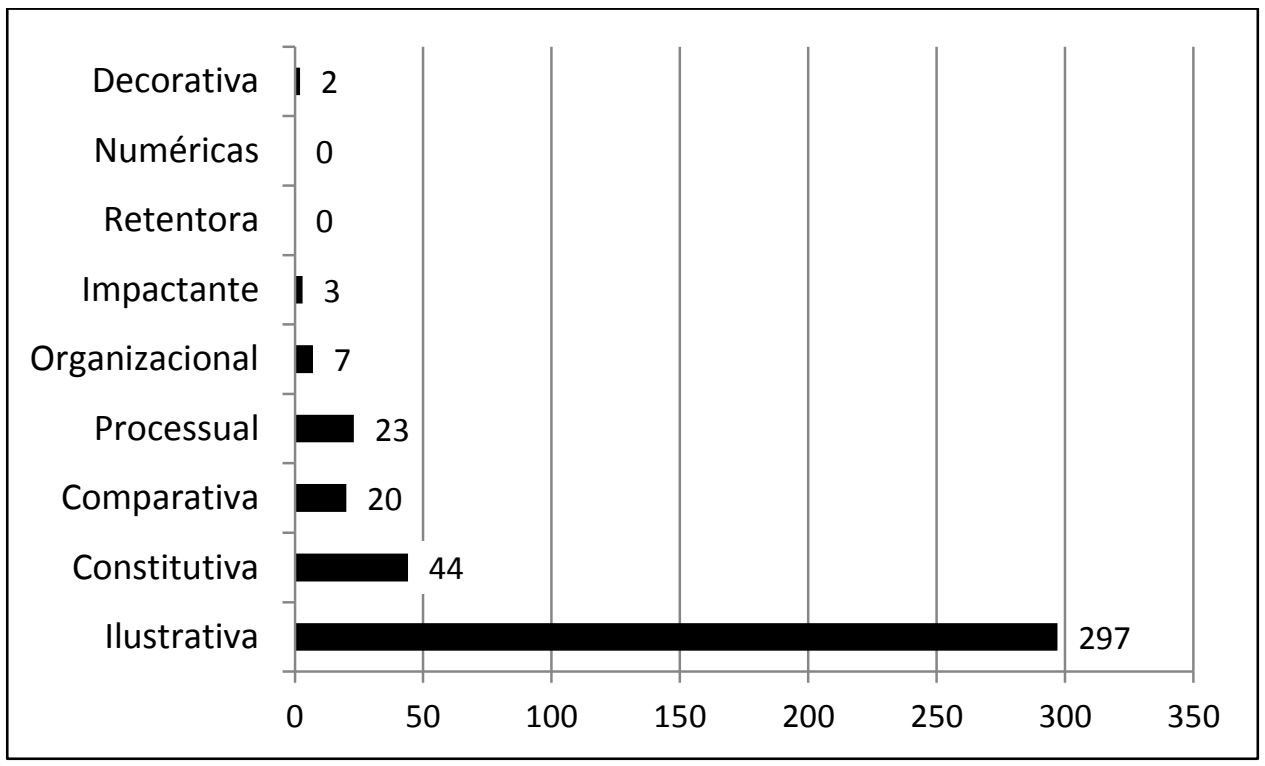

Gráfico 13 - Análise funcional: categorias das imagens do material da disciplina de Diversidade Botânica. 


\subsubsection{Discussão dos Dados da Análise Funcional}

A distribuição das categorias funcionais das imagens é distinta entre os materiais dos três professores sujeitos desta pesquisa. Dessa forma, não podemos dizer que foi encontrado um padrão geral e comum na utilização de imagens no presente estudo de caso. No entanto, pudemos perceber uma tendência de utilização abundante de uma das categorias: a Ilustrativa, que esteve mais presente em todos os materiais, principalmente no fornecido pelo professor da disciplina Diversidade Botânica (75\% do total). Já no caso dos outros dois professores, que abordam conteúdos específicos da zoologia, ocorreu uma maior diversidade nas funções das imagens, apesar das Ilustrativas ainda serem as mais numerosas (29\% para o Prof. A e 35\% para o Prof. B). O Prof. B de Diversidade Zoológica foi o único que utilizou todas as funções da classificação de imagens utilizada no presente trabalho, sendo que as diferentes funções tiveram uma ocorrência mais bem distribuída em relação ao que foi verificado para os outros professores.

Uma possibilidade para este alto índice de imagens Ilustrativas principalmente nas aulas de botânica seria uma necessidade especifica do docente dessa área do conhecimento: enriquecer o repertório de imagens mentais dos alunos sobre as plantas, já que muitos desconhecem as estruturas e espécies estudadas (IAVELBERG, 1995). Autores têm evidenciado que esse repertório realmente deve ser menor se comparado ao de imagens de animais, destacando como possíveis razões para esse maior interesse sobre os animais: a existência de professores de Biologia (Ensino Básico) com afinidade extrema pela Zoologia (zoochauvinismo); uso frequente de exemplos com animais para explicar conceitos e princípios básicos da Biologia (exemplos zoocêntricos); aulas de Botânica muito técnicas e pouco motivadoras; e pouca importância dada a experiências de laboratório e de campo com Botânica (HERSHEY 1996 e 2002, WANDERSEE; SCHUSSLER 1999 e 2001).

Alguns desses autores inclusive cunharam o termo "Cegueira botânica" para se referir à falta de habilidade das pessoas para perceber as plantas no seu próprio ambiente, $\mathrm{o}$ que conduz a: incapacidade de reconhecer a importância das plantas para a biosfera e para os humanos; incapacidade de apreciar a beleza e as características peculiares das plantas; e visão equivocada das plantas como inferiores aos animais, podendo, por isso, serem desprezadas (WANDERSEE; SCHUSSLER, 2001). Assim, o docente de Botânica no ensino superior depara-se com licenciandos que, muitas vezes, não conhecem os organismos sobre os quais a aula versa, existindo a necessidade de apresenta-los utilizando 
imagens Ilustrativas. Isso ajudaria e explicar porque $75 \%$ das imagens encontradas no material do docente da disciplina Diversidade Botânica investigado no presente trabalho são do tipo Ilustrativa.

Esse padrão de alta utilização de imagens do tipo Ilustrativas (detectado mais fortemente na disciplina Diversidade Botânica, mas também presente em Diversidade Zoológica) parece lógico quando pensamos que essas disciplinas que foram objeto de estudo do presente trabalho referem-se à abordagem da biodiversidade em sua dimensão que enfoca principalmente a variedade de organismos, que podem ser apresentados em imagens Ilustrativas. As disciplinas enfocam ainda a apresentação da morfologia de organismos. Dessa forma, também são abundantes imagens de função Constitutiva (que apresentam a constituição dos seres vivos, partes do corpo e etapas do desenvolvimento), como também as imagens Comparativas (que tentam estabelecer comparações entre indivíduos de grupos afins, como também enfocam aspetos evolutivos). Destacamos ainda que o tema biodiversidade apresenta conceituação complicada (MOTOKANE, 2005), abordando não somente aspectos biológicos e/ou evolutivos, mas também a aspectos socioeconômicos, estéticos, conservacionistas e humanos (MARANDINO; MONACO, 2007). Assim, ressaltamos que a alta utilização de imagens Ilustrativas na abordagem da biodiversidade está mais diretamente relacionada aos aspectos biológicos/evolutivos do que aos outros definidos por Marandino e Monaco (2007), uma vez que esse foi o enfoque predominante das disciplinas estudadas no presente trabalho.

Finalmente, podemos inferir, como já esperado, que a utilização das imagens depende muito do tema conceitual abordado no material que é analisado. No caso do presente trabalho, percebemos que as imagens Ilustrativas, seguidas pelas Constitutivas e Comparativas foram as mais utilizadas na abordagem da temática biodiversidade (em enfoque organismos-estruturas). Já no trabalho de Sebata et. al.(2005), cuja temática era o lixo, as imagens expressivas (classificadas no presente trabalho como impactantes) foram mais abundantes, tendo objetivo mais direto de impactar o observador e levá-lo a refletir sobre o tema. Provavelmente, uma temática da Biologia com maior interface com as áreas exatas (como Genética, na parte de cálculo de probabilidades, ou Ecologia, na parte de quantificação da diversidade) utilizaria mais imagens do tipo Numéricas, Data-display ou Lógico-Matemática. 


\section{CONSIDERAÇõES FinAis}

As imagens são ferramentas comunicativas amplamente utilizadas na sociedade atual, uma vez que elas contêm mensagens que podem influenciar ainda mais do que textos verbais, conseguindo ditar o que devemos pensar, sentir, fazer, necessitar e desejar. Moldam nossos pensamentos e condutas (ROSSI, 2009). Dessa forma, a importância das imagens é notória nos dias de hoje.

As imagens também assumem grande importância no meio educacional, como uma ferramenta didática com diversas funções pedagógicas, tais como captar a atenção do aluno e facilitar sua compreensão do conteúdo, principalmente de conceitos mais abstratos. (PERALES; JIMÉNEZ, 2002). São importantes funções reconhecidas: ampliar a capacidade de comparar, descrever, sintetizar, enumerar e discriminar (MARTINS; GOUVÊA, 2001). Em pesquisa realizada em 2011 com 15 docentes do curso de Licenciatura em Ciências da Natureza (na mesma instituição dos sujeitos da presente pesquisa), os participantes destacaram outras funções para as imagens: sintetizar o conteúdo, relaxar/divertir a aula, auxiliar à explicação e introduzir o tema (NAVARRO; URSI, 2011). Martins e colaboradores (2005, pg.39) destacam ainda:

\footnotetext{
“- Localizar estruturas (e suas possíveis funções) e torná-las dinâmicas (movimentos, mudanças de lugar etc.), possibilitando mostrar relações espaciais entre parte e todo;

- Fornecer um cenário no qual alunos e professora podiam pensar, localizar e identificar as entidades e suas partes, apresentando e detalhando essas entidades; Conduzir os processos de construção de representações, seja através de descrições ou estabelecendo analogias;

- Momentos em que as explicações assumiram um caráter menos rígido e possibilitaram uma expressão mais criativa e representativa, inclusive da participação dos alunos na mediação de conceitos e/ou ideias (por exemplo, com o uso de analogias);

- Influenciar na memorização dos alunos (analogias visuais ajudaram a lembrar o nome das organelas) e que os alunos se aproximassem de um universo invisível, inacessível, aumentando a possibilidade de "convencimento" desses alunos."
}

Embora as imagens assumam importantes funções no meio educacional, sendo muitas vezes imprescindíveis na explicação de determinados conceitos (CASSIANO 2002; JIMÉNEZ et. al. 1997), elas não são autossuficientes para o entendimento do conceito. Existe a necessidade de serem exploradas, cabendo ao professor direcionar o olhar dos alunos, os auxiliando a atribuírem significado ao que estão observando e estabelecerem a relação da imagem com o conceito (SILVA et. al. 2006). 
Assim, é importante que o futuro professor do ensino básico, já durante seu processo de formação inicial, tome consciência dessa sua função como auxiliar na interpretação de imagens por parte de seus estudantes. Nessa perspectiva, é importante que docentes de cursos de formação de professores (como em Licenciaturas em Ciências da Natureza) tenham especial atenção à maneira como utilizam as imagens em suas próprias aulas. O presente trabalho teve a intenção de realizar uma primeira análise justamente desse cenário, investigando a utilização geral de imagens e suas funções.

No presente estudo de caso, tivemos como principais achados:

- Há uma tendência, nos materiais analisados, de utilização de imagens do tipo fotográfico, colorido e com função Ilustrativa para abordar a biodiversidade;

- O uso de escalas nas imagens é praticamente nulo;

- Houve um número considerável de imagens com mais de uma função;

- Não há nenhuma legenda no material que lembre o aluno que as imagens são apenas representações e que nem sempre correspondem à realidade, tendo tamanhos e cores aleatórias;

- Há uma quantidade elevada de imagens em cada aula e muitas imagens por slide, sendo apresentadas cerca de 1,69 imagens por slide/página. Sendo que em alguns há mais de 10 imagens;

- O ensino do conteúdo botânico parece demandar maior utilização de imagens Ilustrativas, uma vez que, normalmente, os estudantes conhecem menos as plantas do que os animais, sendo mais frequentemente necessário apresentar/exemplificar os organismos abordados em aula de botânica do que de zoologia.

Como perspectivas futuras de aprofundamento do presente trabalho, sugerimos que, no âmbito da formação inicial de professores de ciências, sejam investigadas questões como:

- Os professores, ao planejarem suas aulas, possuem critérios de escolha e objetivos didáticos para as imagens que utilizam? Quais são tais critérios e objetivos?

- Tais professores refletem de alguma forma sobre a utilização de imagens em suas aulas? Percebem que uma utilização sem reflexão pode contribuir para a formação/consolidação de conceitos equivocados por parte dos estudantes?

- Qual a percepção dos estudantes sobre a utilização de imagens em seu curso de formação? Qual sua avaliação sobre a influência das imagens em seu aprendizado?

- Como ocorre a interação professor-imagem-estudante durante as aulas? 
Assim, podemos destacar que classificar as imagens utilizadas pelos professores sujeitos da presente pesquisa nos mostra certos padrões de utilização e nos oferece subsídios para investigações mais profundas, com base em observações sistemáticas das aulas e entrevistas individualizadas com docentes e estudantes. Tais investigações não eram o foco da presente dissertação, mas são uma possibilidade de futuras pesquisas, tomando o presente trabalho como ponto de partida. 


\section{REFERÊNCIAS BIBLIOGRÁFICAS}

AMADOR, F.; CARNEIRO, H., O papel das imagens nos manuais escolares de ciências naturais no ensino básico: uma análise do conceito de evolução, Revista de Educação, 8 (2), p. 119-129, 1999.

ANDRÉ, M. E. D. A de, Etnografia da prática escolar, 15.ed. Campinas, SP: Papirus, 2008

AUMONT, J., A imagem, trad. Estela dos Santos Abreu e Cláudio C. Santoro; Campinas, SP: Papirus, 1993.

BARROS, M. M; CARNEIRO, M. H. S., Os conhecimentos que os alunos utilizam para ler as imagens de mitose e de meiose e as dificuldades apresentadas, $\mathrm{V}$ ENPEC, n. 5, 2005.

BARTHES, R., A retórica da imagem, In: O óbvio e o obtuso, Rio de Janeiro, RJ: Nova Fronteira, 1990.

BOCK, A. M. B.; FURTADO, O.; Teixeira, M. de L. T., Psicologias: uma introdução ao estudo da psicologia, São Paulo, SP: Saraiva, 2005.

BOURO, A. B., Olhos que pintam: a leitura de imagem e o ensino da arte, São Paulo, SP: Educ./ Fapesp.; Cortez, 2002.

BRUZZO, C., Biologia: Educação e Imagens, Educação e Sociedade, Campinas, v. 25, n. 89, p. 1359-1378, 2004.

CARRASCOSA, J., Análise da Formação Continuada e Permanente dos Professores de Ciências Ibero-Americanos, In: MENEZES, L. C. de (org.), Formação de Professores de Ciências no contexto Ibero-Americano, $2^{\circ}$ ed. Campinas, SP: NUPES, 2001. 
CASSIANO, W. S., Análise de Imagens em Livros Didáticos de Física, Dissertação de Mestrado, Faculdade de Educação, Universidade de Brasília, 2002.

CACHAPUZ, A. F., A Universidade, a Valoração do Ensino e a Formação Docente, In: NETO, A. S.; MACIEL, S. B. (org.), Reflexões sobre a Formação de Professores, Campinas, SP: Papirus, 2002, Coleção Magistério: Formação e Trabalho Pedagógico.

COLOM, A. J. A., A (des) Construção do Conhecimento Pedagógico: novas perspectivas para a educação, Porto Alegre, RS: Artmed, 2004.

COSTA, C., Educação, imagem e mídias, São Paulo, SP: Cortez, 2005.

DONDIS, D. A., Sintaxe da Linguagem Visual, São Paulo, SP: Martins Fontes, 2000.

DUCHASTEL, P. C.; WALleR, R., Pictorial illustration in instructional texts, Educational technology, Englewood Cliffs, v. 19, n. 11, p. 20-25, 1979.

GARCIA, C. M., Formação de professores: para uma mudança educativa, Portugal: Porto Editora, 1999.

HANTZSCHEL, R., Ilusão e credibilidade na imagem fotográfica, Monografia (Pósgraduação) - Senac, São Paulo, 1999-2000. Disponível em $<$ http://www.fotopositivo.com.br/tese/tese.html>. Acesso em: 14 set. 2012.

HENGMÜHLE, A., Formação de Professores: da função de ensinar ao resgate da educação, Petrópolis, RJ: Vozes, 2007.

HERSHEY, D. R., A historical Perspective on Problems in Botany Teaching, American Biology Teacher, v. 58, n. 6, p. 340-347, sep. 1996.

HERSHEY, D. R., Plant Blindness: "we have met the enemy and he is us", Plant Science Bulletin, v. 48, n. 3, p. 78-85, 2002. 
HOFFMANN, J., Avaliação mediadora. Uma prática em construção da pré-escola à universidade, Porto Alegre, RS: Educação \& Realidade, 1993.

IAVELBERG, R., O desenho cultivado na criança. In: CAVALCANTI, Z. (org.), Arte na sala de aula, Porto Alegre, RS: Artes Médicas, 1995.

INGERSOLL, R. M.; PERDA, D, Is the Supply of Mathematics and Science Teachers Sufficient?, In: American Educational Research Journal, Vol. 47, n. 3, p. 563594, September 2010.

JANUARIO, P. C., Formação de formadores: o docente do ensino superior é um profissional da educação, Rio de janeiro, RJ: Revista Soletras, Ano 7, n. 13 p. 46-58, 2007.

JAMESON, F., Transformações da imagem na pós-modernidade, In: Espaço e Imagem, Teorias do pós-moderno e outros ensaios, Rio de Janeiro, RJ: Editora da UFRJ, 1994.

JOLY, M., Introdução à análise da Imagem, Trad. Marina Appenzeller, $11^{\circ}$ ed., São Paulo, SP: Papirus, 2009.

JOTTA, L. A. C. V.; CARNEIRO, M. H. S., As imagens da embriologia animal: uma análise em livros didáticos de biologia, In: Encontros Nacionais de Pesquisa em Educação em Ciências, 5, 2005, Bauru. Anais... São Paulo: ABRAPEC, 2006.

JOTTA, L. A. C. V., Embriologia animal: uma análise dos livros didáticos de Biologia do Ensino Médio, Dissertação de Mestrado, Universidade de Brasília, Brasília, 2005.

LIPPE, E. M. O.; BASTOS, F., Formação inicial de professores de biologia: fatores que influenciam o interesse pela careira do magistério, In: Encontros Nacionais de Pesquisa em Educação em Ciências, n. 6, 2007, Florianópolis. Anais... Belo Horizonte: ABRAPEC, 2008. 
LEONTIEV, A., O desenvolvimento do psiquismo, Lisboa: Horizonte Universitário, 1978.

LOPEZ, A. P. A., As razões e os sentidos, Tese de Doutorado, Universidade de São Paulo, São Paulo, 2000.

LÜDKE, M.; ANDRÉ, M. E. D. A., Pesquisa em educação: abordagens qualitativas, São Paulo, SP: Pedagógica Universitária, 1986.

KISHIMOTO, T. M., O Jogo e a Educação Infantil, In: KISHIMOTO, Tizuko Morchida (org.), Jogo, Brinquedo, Brincadeira e a educação, $5^{\circ}$ ed., São Paulo, SP: Cortez, 2001, p. 13-44.

KRASILCHIK, M., O professor e o currículo das ciências, São Paulo, SP: Editora da Universidade de São Paulo, 1987.

KRESS, G.; VAN LEEUWEN, T., Reading images: the grammar of the visual design, $2^{\circ}$ ed., London: Routledge, 2006.

KÖCHE, J. C., Fundamentos da metodologia científica e iniciação à pesquisa, Petrópolis, RJ: Vozes, 2002.

MARANDINO, M.; MÔNACO, L., Biodiversidade nos Museus: discussões sobre a (in) existência de um discurso sobre conservação em ações educativas dos museus de ciências, In: X Reunión de la Red de Popularización de la Ciencia y la Tecnología em América Latina y el Caribe, (RED POP - UNESCO), 2007.

MARCELlinO, N. C., Estudos do lazer: uma introdução, $4^{\circ}$ ed., Campinas, SP: Autores Associados, 2006.

MARTINS, I., O papel das representações visuais no ensino-aprendizagem de ciências, In: Encontros Nacionais de Pesquisa em Educação em Ciências, n.1, 1997, Águas de Lindóia. Anais... São Paulo, SP: ABRAPEC, 1997. 
MARTINS, I.; GOUVÊA, G.; PICCININI, C., Aprendendo com imagens, Ciência e Cultura, Ano 57, n. 4, p. 38-40, out/nov/dez 2005.

MARTINS, I.; GOUVÊA, G., Imagens e educação em ciências, In: ALVES, Nilda; SGARBI, Paulo (Orgs.), Espaços e imagens na escola, Rio de Janeiro: DP\&A, 2001.

MARTINS, M. H., O que é leitura, 19º ed., São Paulo, SP: Brasiliense, 1994.

MENEZES, L. C. de, Características Convergentes no Ensino de Ciências nos Países Ibero-americanos e na Formação de seus Professores, In: MENEZES, L. C. de (org.), Formação de Professores de Ciências no contexto Ibero-Americano, $2^{\circ}$ ed., Campinas, SP: NUPES, 2001.

MINAYO, M. C. de S., O desafio do conhecimento: pesquisa qualitativa em saúde, $9^{\circ}$ ed., São Paulo, SP: Hucitec, 2006.

MOLES, A. A., Em busca de uma teoria ecológica da imagem?, In: Anne-Marie Thibault-Laulan (ed.) Imagem e Comunicação. São Paulo, SP: Edições Melhoramentos, 1976.

MONTEIRO, J. A; MONTEIRO, S. C. F; AlmADA, E; BARBOSA, J. V., A estéticaexpressiva da biologia: "Ensinando aprendendo" a olhar/ver a célula eucariótica, V ENPEC, n. 5, 2005.

MORAES, R., Mergulhos Discursivos: Análise textual Qualitativa entendida como processo integral de aprender, comunicar e interferir em discursos, In: GALIAZZI, Maria do Carmo \& FREITAS, José Vicente de (org.) Metodologias Emergentes de Pesquisa em Educação Ambiental. Ijuí: Editora da UNIJUI, 2005.

MORETTO, V. P., Prova, um momento privilegiado de estudo, não um acerto de contas, Rio de Janeiro, RJ: DP\&A, 2001. 
MOTOKAME, M. T.; KAWASAKI, C. S.; OLIVEIRA, L. B., Por que a biodiversidade pode ser um tema para o ensino de ciências?, In: MARANDINO, M; MONACO, L. M.; OLIVEIRA, A. D. de, Olhares sobre os diferentes contextos da biodiversidade: pesquisa, divulgação e educação, São Paulo, SP: GEENF / FEUSP/ INCTOX, 2010.

NAVARRO, T. E.; URSI, S., A utilização didática de imagens por formadores de futuros professores de ciência, In: Encontros Nacionais de Pesquisa em Educação em Ciências, n. 6, 2011, Campinas. Anais... São Paulo, SP: ABRAPEC, 2012.

NOVELLINO, M. O., Fotografias em livro didático de inglês como língua estrangeira: Análise de suas funções e significados, Dissertação de Mestrado, Rio de Janeiro, RJ: PUC, Departamento de Letras, 2007.

OLIVEIRA, M. K. de, Vygotsky: aprendizado e desenvolvimento, um processo sócio histórico, 4º ed., São Paulo, SP: Scipione, 2004.

PERALES, F. J.; JIMÉNEZ, J. D., Las ilustraciones en la enseñanza-aprendizaje de las ciencias: análisis de libros de texto, Enseñanza de lãs ciencias, 20, (3), p. 369386, 2002.

PÉREZ, D. G.; CARVAlHO, A. M. P., Formação de professores de Ciências: tendências e inovações, trad. Sandra Valenzuela, $6^{\circ}$ ed., São Paulo, SP: Cortez, 2001, Coleção: Questões da nossa Época.

PEREIRA, Rita M. R.; SOUZA, Solange J., O Uso da Imagem na Pesquisa em Educação: Desafios Contemporâneos, In: $23^{\mathrm{a}}$ REUNIÃO ANUAL - ANPED. Caxambu, 2000, Anais... Rio de Janeiro, RJ: ANPED, 2000.

PERRENOUD, P., Construir competências desde a escola, Porto Alegre: Artes Médicas, 1999.

Ensinar: Agir na urgência, decidir na incerteza, São Paulo, SP: Contexto, 2001, Coleção: repensando a História. 
RANGEL, S.; CUNHA, V., Pedagogia da Imagem, In: DORNELlES, V. L.; SARMENTO, M. J., et. al., Produzindo Pedagogias Interculturais na Infância, Petrópolis, RJ: Vozes, 2007.

RODRIGUES, R. C, Análise e tematização da imagem fotográfica, Ci. Inf., Brasília, v. 36, n. 3, p. 67-76, set./dez. 2007.

ROSSI, M. H. W., Imagens que falam: leitura da arte na escola, $4^{\circ}$ ed., Porto Alegre, RS: Mediação, 2009, Coleção: Educação e Arte.

SANTAELLA, L; NÖTH, W., Imagem: Cognição, semiótica, mídia, São Paulo, SP: Iluminuras, 2008.

SANTAELlA, L., A percepção: uma teoria semiótica, $2^{\circ}$ ed., São Paulo, SP: Experimentos, 1998.

SANTOS, L. L. C. P., Formação de Professores e Saberes Docentes, In: NETO, A. S.; MACIEL, S. B. (org.), Reflexões sobre a Formação de Professores, Campinas, SP: Papirus, 2002, Coleção Magistério: Formação e Trabalho Pedagógico.

SEBATA, C. E; SANTOS, W. L. P; CARNEIRO, M. H. S., "As imagens em textos didáticos de temas sociais em um livro didático de química: Análise de seu papel pedagógico", In: Encontros Nacionais de Pesquisa em Educação em Ciências, 5, 2005, Bauru: SP, Anais... São Paulo, SP: ABRAPEC, 2006.

SGARBI, P., Colando textos, colando imagens, In: ALVES, N.; SGARBI, P. (orgs.) Espaços e imagens na escola, Rio de Janeiro, RJ: DP\&A, 2001.

SILVA, H. C., Discursos e leituras da física na escola: uma abordagem introdutória da síntese newtoniana para o ensino médio, Brasília, DF: Universa, 2004.

SILVA, H. C.; ZIMMERMANN, E.; CARNEIRO, M. H. S.; GASTAL, M. L.;CASSIANO, W. S., Cautela ao usar imagens em aulas de ciências, Revista Ciência \& Educação, v. 12, n. 2, p. 219 - 233, 2006. 
SILVA, P. G. P. da; CAVASSAN, O., A influência da imagem estrangeira para o estudo da botânica no ensino fundamental, In: Encontros Nacionais de Pesquisa em Educação em Ciências, Bauru, SP: Anais... Bauru: SP: ABRAPEC, 2005

SOUZA, S. M. R. de; SANTARELLI, C. P. G., Contribuições para uma história da análise da imagem no anúncio publicitário, Intercom Revista Brasileira de Ciências da Comunicação, São Paulo, v. 31, n.1, p. 133-156, jan./jun., 2008.

TARDIF, M., Saberes docentes e formação profissional, 4º ed. Petrópolis: Vozes, 2004.

THERRIEN, J., O saber do trabalho docente e formação do professor, In: NETO, A. S., MACIEL, S. B. (org.), Reflexões sobre a formação de professores, Campinas, SP: Papirus, 2002, Coleção Magistério: Formação e Trabalho Pedagógico.

VYGOTSKY, L. S., La imaginación y el arte em la infância: ensayo psicológico, $5^{\circ}$ ed., Madrid: AKAL S. A., 2000 (Trabalho original publicado em 1930).

VYGOTSKY, L. S., org. Michael Cole et al.; tradução José C. Neto, Luís S. M. Barreto, Solange C. Afeche, A formação social da mente: o desenvolvimento dos processos psicológicos superiores, São Paulo, SP: Martins Fontes, 2003.

VYGOTSKY, L.S., Pensamento e Linguagem, São Paulo, SP: Martins Fontes, 1998.

WANDERSEE, J. H.; SCHUSSleR, E. E., Preventing Plant Blindness, American Biology Teacher, v. 61, n. 2, p. 84-86, feb. 1999.

WANDERSEE, J. H.; SCHUSSLER, E. E, Towards a Theory of Plant Blindness, Plant Science Bulletin, v. 47, n. 1, p. 2-9, 2001.

ZATZ, L., Aventura da escrita. A história do desenho que virou letra, São Paulo, SP: Moderna,1991. 